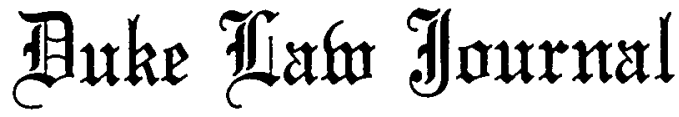

\section{COMPARATIVE NEGLIGENCE VERSUS THE CONSTITUTIONAL GUARANTEE OF EQUAL PROTECTION: A HYPOTHETICAL JUDICIAL DECISION}

\author{
Claude R. Sowle* and Daniel O. Conkle**
}

\section{Prologue}

A substantial majority of American jurisdictions have now adopted comparative negligence to replace the traditional rule that contributory negligence is a complete defense in neghigence actions. The transition to comparative negligence, however, has been fraught with difficulty. Giving shape and content to the doctrine has proven an unexpectedly challenging and perplexing task for judges, lawyers, and scholars. Perhaps not surprisingly, this preoccupation with the structure of the doctrine has left the constitutional implications of comparative negligence virtually ignored. Our purpose is to fill this void. Although our primary focus is upon those jurisdictions (now twenty-six in number) that have adopted some forn of "partial" comparative neghigence, the implications of our analysis extend beyond the boundaries of those states. Also within the range of our discussion are those jurisdictions that einploy "pure" coinparative negligence for the benefit of

* Professor of Law, The Ohio State University; B.S. 1950, J.D. 1956, Northwestern University.

** Menuber, Ohio Bar; B.A. 1976, J.D. 1979, The Ohio State University.

The authors gratefully acknowledge the valuable suggestions of Professor Victor E. Schwartz of the University of Cincinnati College of Law, Distinguished Professor John W. Wade of the Vanderbilt University School of Law, and Dean Janes E. Meeks, Professor Michael John Perry, and Professor Kathryn Dix Sowle of The Ohio State University College of Law. The authors also wish to thank Richard M. Stillwell, a 1979 graduate of The Ohio State University College of Law, for his research assistance.

THE FOLLOWING CITATION WILL BE USED IN THIS ARTICLE:

V. Schwartz, Comparative Negligence (1974 \& Supp. 1978) [hereinafter cited as V. SCHWARTZ]. 
plaintiffs in basic neghigence actions but that deal less generously with defendants seeking contribution froin co-tortfeasors. In addition, there are implications for those states that resolve issues of contribution on a pure comparative neghigence basis but retain the absolute bar of contributory negligence in actions between plaintiffs and defendants. Indeed, our analysis suggests that only four states-those in which the doctrine of pure comparative neghigence is inade available to both plaintiffs seeking dainages and defendants seeking contribution-1naintain loss distribution systems that are free from constititutional doubt. ${ }^{\dagger}$

The principal goal of this Article is to stimulate proinpt, widespread, and thorough consideration of the constitutional issues we have raised. To this end, we have sought to attain four subsidiary objectives: first, to capture the attention and imagination of those who are in a position to influence the course of legal events; second, to convince those persons that the constitutional problems we discuss are both real and urgent; third, to deinonstrate that any resolution of the issues raised ultimately will turn upon a choice between two profoundly different approaches to the role of courts in assessing constitutional challenges to tort doctrine; and, fourth, to articulate our thoughts in a forin and style congenial to the needs of those who draft briefs and write court opimons. Smith v. Acme Corporation, the fictitious decision that follows, represents our efforts to nieet these requireinents. The hypothetical judicial opimon, although by no means unknown in American legal journals, ${ }^{+\dagger}$ is not a conventional form of scholarship, but it appealed to us as the expository vehicle best suited to our purpose.

While the principal and ancillary opinions in Smith are imaginary, the statutory and precedential tools used in their construction are real. As our source of local law, we have selected Wisconsin, a state whose

$\dagger$ The four states are California, Florida, New York, and Rhode Island.

California: Li v. Yellow Cab Co., 13 Cal. 3d 804, 532 P.2d 1226, 119 Cal. Rptr. 858 (1975) (adopting pure comparative negligence); American Motorcycle Ass'n v. Superior Court, 20 Cal. 3d 578,578 P.2d 899, 146 Cal. Rptr. 182 (1978) (authorizing contribution on a pure comparative fault basis under the rubric "common law partial equitable indemnity").

Florida: Hoffman v. Jones, 280 So. 2d 431 (Fla. 1973) (adopting pure comparative negligence); FLA. STAT. ANN. §768.31(3)(a) (West Supp. 1979) (authorizing contribution on a pure comparative fault basis).

New York: N.Y. CIV. Prac. LAW $\$ 1411$ (McKinney 1976) (adopting pure comparative negligence); N.Y. CIV. PRAC. LAW $\S \S 1401,1402$ (McKinney 1976) (authorizing contribution on a pure comparative fault basis).

Rhode Island: R.I. GEN. LAws $\$ 9-20-4$ (Supp. 1978) (adopting pure comparative negligence); R.I. GEN. LAws $\S 10-6-3$ (Supp. 1978) (authorizing contribution on a pure comparative fault basis).

t† See, e.g., Fuller, The Case of the Speluncean Explorers, 62 HARv. L. Rev. 616 (1949); Keeton, Creative Continuity in the Law of Torts, 75 HARv. L. REv. 463, 508-09 (1962); Wadlington, A Case of Insanity and Divorce, 56 VA. L. REv. 12 (1970). 
uneasy and litigious marriage to partial comparative negligence began nearly fifty years ago. Our tribunal is a fictitious seven-member panel of the Supreme Court of Wisconsm.

\section{TABLE OF CONTENTS}

SMITH V. ACME CORPORATION

Opinion of ADAMS, J., for the Court

I. The Doctrines of Contributory and Comparative

Negligence..................................... 1086

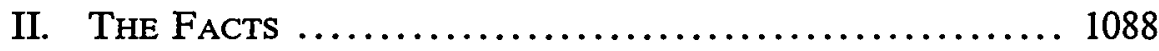

III. The Trial ..................................... 1089

IV. The Nonconstitutional Issue................... 1091

V. The Constitutional Issues ........................ 1093

A. Plaintiff's Constitutional Contentions .............. 1093

B. Standards to be Applied in Evaluating Plaintiff's Constitutional Contentions ............................ 1095

1. Federal Constitutional Law.................... 1095

2. Wisconsin Constitutional Law ............... 1102

C. Discussion and Evaluation of Plaintiff's Constitutional

Contentions and Defendant's Responses Thereto ....... 1111

1. The 50\% Cut-Off Line ..................... 1111

2. The Presence of "Pure Contribution"............ 1124

3. Defendant's "One Step at a Time" Argument ...... 1133

VI. CoNClusion AND Disposition of APPEAL ............. 1135

A. Alternatives Available in the Selection of a New System of

Loss Distribution ............................ 1135

1. Reinstatement of the Doctrine of Contributory Negligence.................................. 1135

2. Adoption of a "Uniform Discount System" ....... 1136

3. Adoption of Pure Comparative Negligence ......... 1138

B. The Issue of Retroactive Application................ 1142 Opinion of BAKER, J., Concurring im Part and Concurring im Re-

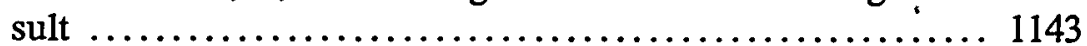

Opinion of CARR, J., Concurring ...................... 1144

Opinion of DoE, J., Concurring and Dissentimg ............. 1145 Opinion of Ellıs, J., Dissenting ...................... 1148

\section{SMITH V. ACME CORPORATION}

ADAMS, J. It would be difficult to iniagime a case less complicated than this one were we required merely to apply the law of negligence as it presently exists in the state of Wisconsim. The basic facts are 
not in dispute, there is credible evidence to support the conclusions reached by the jury, and the statute mandating entry of judginent for defendant is clear and unequivocal. But the case is not a simple one, for plaintiff, in resisting the dismissal of her action, has mounted a strong attack upon the constitutionality of Wis. Stat. Ann. § 895.045 (West Supp. 1978-79), the current version of a statutory scheme that, since 1931, has controlled our resolution of contributory neghigence issues. Section 895.045 , Stats., provides:

Contributory negligence shall not bar recovery in an action by any person or his legal representative to recover dainages for neghgence resulting in death or in injury to person or property, if such negligence was not greater than the negligence of the person against whom recovery is sought, but any damages allowed shall be diminished in the proportion to the amount of neghigence attributable to the person recovering. ${ }^{1}$

In order to provide a proper foundation for our consideration of the issues presented in this case, we turn first to a brief discussion of contributory and comparative negligence, the two doctrines that lie at the lieart of this dispute.

\section{The Doctrines of Contributory and Comparative NegLigence}

Contributory negligence is conduct of the plaintiff that falls below the standard of reasonable care lie is required to exercise for his own protection and that contributes to an injury also caused by the defendant's failure to exercise reasonable care under the circumstances. ${ }^{2} \mathrm{Al}-$ though certain exceptions have been recognized, ${ }^{3}$ contributory negligence on the part of a plaintiff traditionally has barred his recovery against a defendant who would otherwise be liable for the harin suffered. 4

In contrast to the "all or nothing" thrust of the traditional contributory negligence rule, the doctrine of comparative negligence proceeds on the theory that damages in a neghigence action should be apportioned between the parties on the basis of relative fault. 5 Under "pure" comparative negligence, a contributorily negligent plaintiff may re-

\footnotetext{
1. WIs. Stat. ANN. $\$ 895.045$ (West Supp. 1978-79) (emphasis added).

2. See Restatement (SECOND) OF TORTS $\$ \S 463,464$ (1965).

3. The exceptions are discussed in W. Prosser, HANDBOOK OF THE LAW OF TORTS $\S \S 65$, 66 (4th ed. 1971).

4. See Restatement, supra note $2, \S 467$.

5. See V. SCHWARTZ § 1.3, at 9. "The term 'comparative negligence' might be used to describe any system of law that by some method, in some situations, apportions costs of an accident, at least im part, on the basis of the relative fault of the responsible parties." Id. $\$ 2.1$, at 31 .
} 
cover irrespective of his degree or percentage of fault, but his damages are reduced in proportion to the amount of negligence attributed to him by the fact-finder. ${ }^{6}$ Under the typical versions of "partial" or "Inodified" comparative negligence, a contributorily negligent plaimtiff is permitted a recovery diminislied by the percentage of his negligence as long as his fault is "not as great as" that of the defendant or, under an alternative formulation, "not greater than" that of the defendant." If, however, the plaintiff's contributory negligence is found to exceed the specified limit, the traditional contributory neghigence rule is applied and no recovery is permitted. ${ }^{8}$

Principally as a result of legislative enactments within the last decade, a substantial majority of American states have now turned away from the traditional contributory negligence rule and have embraced the doctrine of comparative negligence. 9 In the words of Professor Schwartz, "[t] he march of comparative negligence is now a stampede." 10 For the nost part, however, this "stampede" has moved toward an unlikely marriage of comparative negligence apportionment

6. Id. $\$ 2.1$, at 32 .

7. Id. $32-33$.

8. Id. 33 .

9. Id. $\S 1.1$, at 3 ; id. 1 (Supp. 1978). Thus far, 36 jurisdictions have adopted some form of comparative negligence. See United States v. Reliable Transfer Co., 421 U.S. 397 (1975); Kaatz v. State, 540 P.2d 1037 (Alaska 1975); Li v. Yellow Cab Co., 13 Cal. 3d 804, 532 P.2d 1226, 119 Cal. Rptr. 858 (1975); Hoffman v. Jones, 280 So. $2 d 431$ (Fla. 1973); Placek v. City of Sterling Heights, 405 Mich. 638, 275 N.W.2d 511 (1979); Bradley v. Appalachian Power Co., 256 S.E.2d 879 (W. Va. 1979); ARK. Stat. ANN. $\$ \$ 27-1763$ to 1765 (1979); Colo. Rev. StaT. \& 13-21-111 (1973); CONN. GEN. STAT. § 52-572h (Supp. 1979); GA. CoDE ANN. \$§ 66-402 (1979), 94-703 (1978), $105-$ 603 (1972); Haw. Rev. STAT. $§ 663-31$ (1976); IDAho Code $\$ \S 6-801$ to 6-806 (1979); Kan. Stat. ANN. § 60-258a, -258b (1976); 1979 La. Sess. Law Serv. act 431 (West); ME. Rev. STAT. ANN. tit. 14, \& 156 (West Supp. 1979); Mass. Gen. Laws ANN. ch. 231, §85 (West Supp. 1979); MinN. StaT. ANN. § 604.01 (West Supp. 1979), as amended, 1978 Minn. Sess. Laws Serv. (West) ch. 738, $\S \S 6-8$; Miss. CODE ANN. § 11-7-15 (1972); Mont. Rev. Codes ANN. §§ 58-607.1 (Supp. 1977); Neb. Rev. Stat. § 25-1151 (Supp. 1978); N.H. Rev. Stat. ANn. § 507:7a (Supp. 1977); Nev. Rev. Star. ch. 41.141 (1977); N.J. Stat. ANN. $\$ \$ 2 A: 15-5.1$ to .3 (West Supp. 1979); N.Y. Civ. PRac. LAW $\S 1411$ (McKinney Supp. 1977); N.D. Cenr. Code $§ 9-10-07$ (1975); OKLA. STaT. ANN. tit. 23, $\S \$ 11-12$ (West Supp. 1978); OR. Rev. STat. $\$ 18.470$ (1977); PA. STat. ANN. tit. 42, § 7102 (Purdon Supp. 1979); R.I. Gen. Laws § 9-20-4 (Supp. 1978); S.D. Compiled Laws ANn. § 20-9-2 (1967); Tex. Rev. Civ. Stat. AnN. art. 2212a, \& 1 (Vernon Supp. 1978); Utah Code ANN. § 7827-37 (1977); Vr. Stat. ANn. tit. 12, § 1036 (1973); WaSh. Rev. Code ANN. $§ 4.22 .010$ (Supp. 1978); Wis. STat. ANN. § 895.045 (West Supp. 1978); Wyo. STaT. \& 1-1-109 (1977).

10. V. SchwarTz $\& 1.1$, at I (Supp. 1978). "Comparative neghigence, once the Cinderella of American law, is at long last blossommg into a princess." Fleming, The Supreme Court of California 1974-75-Foreword: Comparative Negligence at Last-By Judicial Choice, 64 CAL. L. REv. 239, 239 (1976). As to the reason for the sudden transformation, Professor Fleming offers the following:

Not so much legislative inertia as a rigorous lobby mounted by the insurance industry and defense organizations had for generations successfully blocked persistent efforts at reform. This scene underwent a dramatic change when no-fault plans were unveiled. Opponents of these plans sought to retrieve the substance of the cominon law fault sys- 
principles and the traditional "all or nothing" contributory negligence principle, in that most comparative negligence states employ only a partial form of comparative negligence. ${ }^{11}$ As Dean Prosser has noted, the traditional contributory negligence rule is "a chronic invalid who will not die." 12

In the state of Wisconsm, this court adopted the doctrine of contributory negligence in $1858 .{ }^{13}$ It remained the law of Wisconsin until 1931, when the legislature enacted a partial comparative negligence statute that renioved the bar of contributory negligence and permitted a diminished recovery when a plamtiff's contributory negligence "was not as great as the negligence of the person against whom recovery is sought . . . ."14 In 1971 the legislature amended the statute to permit a diminished recovery by a plamtiff whose contributory negligence "was not greater than the negligence of the person agamst whon recovery is sought . . . ."1s By this change in statutory language, the 1971 amendment narrowed, by a slight degree, the remaining scope in Wisconsin of the traditional contributory negligence bar. The statute has not been altered since 1971.

\section{The FACTS}

The headquarters of the defendant, Acme Corporation, are located in the city of Maywood. Next to the headquarters building is a parking lot owned and maintained by Acnie for use by its employees. At the time of the injury that gave rise to this action, the lot had a surface of crushed gravel. When cars would depart froni the lot, they would throw gravel onto a sidewalk that runs parallel to the lot and crosses the lot's entry and exit lanes. Although Acme's groundskeeper periodically swept these stones from the sidewalk, significant amounts of gravel were sometimes allowed to accumulate.

tem by half-heartcdly offering for sacrifice such notorious culprits as the absolute bar of contributory neghigence.

Id. (footnote omitted).

11. See V. SchWARTZ $\$ 2.1$, at 33; id. 8 (Supp. 1978).

12. W. Prosser, supra note $3, \S 65$, at 418 .

13. Chamberlaim v. Milwaukee \& Miss. R.R., 7 Wis. 425 , 431 (1858); Dressler v. Davis, 7 Wis. 527, 531 (1858).

14. 1931 Wis. Laws ch. 242 (current version at W1s. STAT. ANN. $§ 895.045$ (West Supp. 197879)) (emphasis added). For some years prior to this 1931 adoption of a comparative negligence statute of general application, Wisconsin did apply the doctrine of partial comparative neghigence in cases concerning injuries to railroad employees. See 1913 Wis. Laws ch. 644, $\S 192.55$ (current version at W1s. STAT. ANN. § 192.50(2), (3) (West 1957)). The history of this legislation is discussed in Vincent v. Pabst Brewing Co., 47 Wis. 2d 120, 133-34, 177 N.W.2d 513, 519 (1970) (Hallows, C.J., dissenting).

15. 1971 Wis. Laws ch. 47 (codified at Wis. Stats. AnN. $\$ 895.045$ (West Supp. 1978-79)) (emphasis added). 
On July 6, 1976, the plaintiff, Mary Smith, left her place of employinent, a candy factory in Maywood, and began a two-mile walk to her home. Ms. Smith, who was then fifty-six years of age, normally was driven to and from the factory by a co-worker. On this occasion, however, her driver was absent from work, and therefore it was necessary for Ms. Smith to walk hoine. At about 4:15 p.m., she was walking along the sidewalk adjacent to Acme's parking lot. As she reached the portion of the sidewalk that crosses the exit lane of the lot, she stepped on some stones, lost her balance, and fell forward, striking her face on the sidewalk.

An einployee of Acme who observed Ms. Smith's fall called an ambulance. Ms. Smith was removed to a nearby hospital, where a physician determined that she had suffered a compound nasal fracture with a deviated nasal septum. The physician advised immediate corrective surgery, and Ms. Smith consented. Three incisions, two on the outside of her nose and one on the inside, were required to effect the necessary repairs.

After three days in the hospital, Ms. Smith was released. On the advice of her surgeon, she did not work for the next month. On August 9, 1976, the surgeon informed Ms. Smith that there was no need for further treatment, and that she was free to return to work. She resumed her employinent on August 11, 1976. The accident has left Ms. Smith with a shght deformity of her nose as well as two visible surgical scars.

\section{The Trial}

On October 26, 1976, Ms. Smith filed suit agamst the Acme Corporation, allegimg that the defendant corporation had neghigently failed to keep im proper condition that portion of the sidewalk that crosses the exit lane of its parking lot. Acme, in its answer, denied that it was neghigent and alleged that plaintiff's own negligence was the sole proxinuate cause of her accident and resulting mjuries.

On July 18 and 19, 1978, the case was tried before a jury. The evidence established that when Acme constructed its parking lot im 1973, it decided not to blacktop the surface because of the substantial cost involved. It used crushed gravel instead. Following the mitial surfacing of the lot in 1973, Acme found it necessary to add gravel to the surface periodically. In late June 1976, approximately two weeks before Ms. Smith's accident, five truckloads of gravel had been added to the lot. Because the accuniulation of stones on the sidewalk adjacent to the lot tended to be heavier than usual for several weeks following the placement of additional gravel, Acme had directed its groundskeeper to sweep the sidewalk at least twice daily during such periods "if 
he had time." The groundskeeper testified that although he had swept the sidewalk "frequently" during late June and early July of 1976, he could not recall whether he had swept the sidewalk on the day of Ms. Smith's accident.

A witness to the occurrence testified that there had been stones "all over the sidewalk" at the point where Ms. Smith fell. Ms. Smith, in her testimony regarding the accident, stated that she had not seen these stones prior to her fall. She offered no explanation for her failure to observe the stones, except to state that she had walked past the Acme lot only three or four times since it was placed in operation in 1973, and therefore she had not been well acquainted with the area.

The trial court, as a part of its instructions to the jury, required the fact-finders to respond to several interrogatories based upon our partial comparative negligence statute. ${ }^{16}$ The jury returned a special verdict in which it found that both plaintiff and defendant had been negligent and that the negligence of each had been a proximate cause of the accident. The jury furtlier found the proportions of negligence to be $55 \%$ attributable to plaintiff and $45 \%$ attributable to defendant. The jury determined that plaimtiff's total damages were $\$ 16,500$, of whiclı $\$ 450$ was for lost wages, $\$ 1,050$ was for medical and hospital expenses, and $\$ 15,000$ was for pain and suffering and the disfigurement of lier nose.

After the verdict was announced, plaintiff filed two motions. These motions, we assume, were prompted by plaintiff's recognition that the jury's allocation of causal negligence, if accepted by the trial court, perforce would bar her recovery of any portion of the $\$ 16,500$ in damages found by the jury. The first inotion asked that the jury's special verdict on the comparative negligence question be set aside on the ground that it was contrary to the inanifest weiglt of the evidence, and requested that the trial court either order a new trial on the comparison issue or find, as a matter of law, that plaintiff's negligence liad been either less than or equal to that of defendant. This latter alternative would permit the court, consistent witl the provisions of section 895.045, Stats., to enter judgment for plamtiff for at least $50 \%$ of her damages. The second motion asked the trial court to declare section 895.045, Stats., unconstitutional and to adopt in its place a system of pure comparative negligence, thereby permitting the court to enter judgment for plaintiff in the amount of her damages diminished by $55 \%$, the percentage of causal negligence attributed to her by the jury.

16. The court, following Wisconsin precedent, did not instruct the jury concerning the legal effect of the findings it would make by special verdict. See Kobelinski v. Milwaukee \& Suburban Transp. Corp., 56 Wis. 2d 504, 520, 202 N.W.2d 415, 425 (1972). For a discussion of plaintiff's challenge to this Wisconsin rule of law, see note 25 infra. 
Defendant responded to plaintiff's inotions by contending there was credible evidence to support the jury's apportionment of neghigence, and that section 895.045 , Stats., is constitutional. ${ }^{17}$

On August 25, 1978, the trial court denied plaintiff's motions, dismissed her complaint, and entered judgment for defendant. Plaintiff has appealed from the denial of her motions and the judgment entered on the verdict.

\section{The Nonconstitutional Issue}

Plaintiff contends that the jury's allocation of 55\% causal negligence to her and $45 \%$ to defendant is unsupported by the evidence. Should we find this contention meritorious, we could grant relief to plaintiff without reaching the constitutional issues she has raised.

The standard to be apphed in assessing plaintiff's nonconstitutional argument is clear. As we stated in Maus v. Cook, 15 Wis. 2d 203, 112 N.W.2d 589 (1961):

When a jury's findings are attacked on appeal, particularly when they have the trial court's approval, our inquiry is limited to the issue whether there is any credible evidence that, under any reasonable view, supports such findings. . . . The court is particularly loath to overturn a jury verdict on the comparison of the negligence between a plaintiff and a defendant. . . . It is only in unusual fact situations that the court will disturb the jury's comparative negligence answers. ${ }^{18}$

Although we are reluctant to set aside a jury's apportionment of negligence, plaintiff correctly observes that we have felt compelled to do so on a number of occasions. In some cases we have set aside what we believed to be an unreasonable jury apportionment determination and, when the record clearly supported such action, replaced it with our own or that of the trial court and entered final judgment consistent with the provisions of section 895.045 , Stats. ${ }^{19}$ In other cases, when the

17. Plaintiff's constitutional contentions and defendant's responses thereto are analyzed in Part $\mathrm{V}$ of this opinion infra.

18. 15 Wis. $2 \mathrm{~d}$ at $206-07,112$ N.W.2d at 591 . In Maus, apphcation of the standard resulted in a determination that there was credible evidence to support the jury's apportionment of neghgence. For other cases reaching the same result, see, e.g., McGowan v. Story, 70 Wis. 2d 189, 234 N.W.2d 325 (1975); Davis v. Allstate Ins. Co., 55 Wis. 2d 56, 197 N.W.2d 734 (1972); Holzein v. Mueller, 54 Wis. 2d 388, 195 N.W.2d 635 (1972); Bourassa v. Gateway Erectors, Inc., 54 Wis. 2d 176, 194 N.W.2d 602 (1972); Frederick v. Hotel Invs., Inc., 48 Wis. 2d 429, 180 N.W.2d 562 (1970); Jensen v. Rural Mut. lns. Co., 41 Wis. 2d 36, 163 N.W.2d 158 (1968); Van Wie v. Hill, 15 Wis. 2d 98, 112 N.W.2d 168 (1961); Evjen v. Packer City Transit Line, Inc., 9 Wis. 2d 153, 100 N.W.2d 580 (1960); Kraskey v. Johnson, 266 Wis. 201, 63 N.W.2d 112 (1954).

19. Typically, such decisions have been based upon a determination that the evidence of the plaintiff's contributory negligence was so clear and its quantum so great that recovery was barred, as a matter of law, under the terms of our comparative negligence statute. See, e.g., Hollie v. 
evidence in the record was not sufficient to support a new apportionment as a matter of law but did indicate a probable miscarriage of justice on the apportionment question, we have exercised our discretionary powers ${ }^{20}$ and either granted a new trial on the apportionment issue or sustained such an action by the trial court. ${ }^{21}$ Relying upon these decisions, plaintiff argues that corrective action is required in this case, and that we should either reapportion the negligence ourselves or grant her a new trial on the apportionment issue.

Both plaintiff and defendant played substantial roles in bringing about this unfortunate accident, ${ }^{22}$ and the question of how much causal negligence to attribute to each party doubtless was difficult for the jury to answer. Had we been cast in the role of jurors, we might have assessed the fault differently, but there is credible evidence to support the jury's verdict, and our preferences therefore are not controlling. Only in instances of patent unreasonableness should we act to disturb a jury's apportionment. This is not such a case. ${ }^{23}$

Gilbertson, 38 Wis. 2d 245, 156 N.W.2d 462 (1968); Blanchard v. Terpstra, 37 Wis. 2d 292, 155 N.W.2d 156 (1967); Rewolinski v. Harley Davidson Motor Co., 32 Wis. 2d 680, 146 N.W.2d 485 (1966); Drake v. Farmers Mut. Auto. Ins. Co., 22 Wis. 2d 56, 128 N.W.2d 41 (1964); Home Fire \& Marine Ins. Co. v. Farmers Mut. Auto. Ins. Co., 274 Wis. 210, 79 N.W.2d 834 (1956); Quady v. Sickl, 260 Wis. 348, 51 N.W.2d 3 (1952); Piesik v. Deuster, 243 Wis. 598, 11 N.W.2d 358 (1943); Evanich v. Milwaukee Elec. Ry. \& Light Co., 237 Wis. 111, 295 N.W. 44 (1940); Hustad v. Evetts, 230 Wis. 292, 282 N.W. 595 (1938).

20. Our authority comes from WIs. STAT. ANN. $\$ 751.06$ (West Supp. 1979), which provides that "the [supreme] court may reverse the judgment . . . appealed from . . . and . . . remit the case to the trial court . . . for a new trial" should it appear to the court "from the record . . that it is probable that justice has for any reason miscarried ...." Similarly, WIS. Stat. ANN. $\S 270.49$ (West 1971) authorizes a trial court to grant a new trial if "the verdict is contrary to law or to the evidence" or if such an action is "in the interest of justice."

21. A "probable miscarriage of justice" is established if, after a careful review, this court concludes that the jury's apportionment of negligence was without even minimal support in the record. See, e.g., Gross v. Denow, 61 Wis. 2d 40, 212 N.W.2d 2 (1973); Klinzing v. Huck, 45 Wis. 2d 458, 173 N.W.2d 159 (1970); Lawver v. City of Park Falls, 35 Wis. 2d 308, 151 N.W.2d 68 (1967); Caldwell v. Piggly-Wiggly Madison Co., 32 Wis. 2d 447, 145 N.W.2d 745 (1966); Firkus v. Rombalski, 25 Wis. 2d 352, 130 N.W.2d 835 (1964).

22. Defendant owed a duty to users of the sidewalk to take reasonable steps to elininate the hazardous conditions it had created. Defendant breached this duty. lts efforts, at best, were haphazard and inadequate. Plaintiff had an obligation to exercise due care for her own safety. She failed to use such care. Had plaintiff paid attention to conditions underfoot, she would have observed the stones and probably avoided the fall.

23. For a case reaching a similar conclusion on facts virtually indistinguishable from the facts of this case, see Barber v. City of Oshkosh, 35 Wis. 2d 751, 151 N.W.2d 739 (1967). In Barber, the trial court set aside a jury verdict attributing $60 \%$ negligence to the plaintiff and $40 \%$ to the defendant and granted the plaintiff a new trial on the comparison issue. We reversed, reinstated the jury's verdict, and entered judgment for the defendant. In support of our action, we stated, "this is a case where credible evidence exists to support the jury's apportionment of negligence. . . . This is not such an unusual case that in view of the entire record the trial court was entitled to disturb the apportionment." Id. at 754, 151 N.W.2d at 741. 
In light of our inability to respond favorably to plaintiff's nonconstitutional contention, we turn now to her attack upon the constitutionality of section 895.045 , Stats. ${ }^{24}$

\section{The Constitutional Issues}

\section{A. Plaintiff's Constitutional Contentions.}

Althouglı plaintiff alleges other constitutional defects in the statute, ${ }^{25}$ her primary constitutional argument is that section 895.045,

24. Justice Carr, in his concurring opinion infra, correctly notes that twice in recent years a najority of the inembers of this court have expressed the view that the legislature, in partially removing the bar of contributory negligence, did not intend to preempt the common law authority of the court to remove the bar completely and to adopt a pure comparative negligence system. See Lupie v. Hartzheim, 54 Wis. 2d 415, 417, 195 N.W.2d 461, 462 (1972); Vincent v. Pabst Brewing Co., 47 Wis. 2d 120, 130-31, 140, 177 N.W.2d 513, 517-18, 522 (1970) (Wilkie, J., concurring, and Hallows, C.J., dissenting). Justice Carr beheves the court should invoke this previously expressed common law prerogative in the instant case, thereby permitting us to grant relief to plaintiff without reaching the constitutional issues she has raised. The short answer to Justice Carr's suggestion is that the court, after further consideration, has concluded that the views on the issue of preemption expressed in Vincent and Lupie are unsound and therefore should not be utilized in disposing of this appeal. We believe that Justice Hanley was correct in Vincent when he stated:

The statute says: "Contributory negligence shall not bar recovery * * if such [negligence of the party seeking recovery is] not as great as the negligence of the person against whom recovery is sought, ***" The natural inference is that if one's negligence is as great, or greater, than the party against whom recovery is sought recovery is denied. Id. at 127,177 N.W.2d at 516 (emphasis in original). A long-time student of Wisconsin's tort law has expressed a similar view:

The [statutory] doctrine which bars recovery by a claimant who is 50 percent or more negligent is the common law bar rule at a different level. It is a misfit in a systein designed to distribute responsibility according to degrees of fault. It should be repealed. This is a statutory rule and the court is helpless. If the legislature had never developed a comparative negligence doctrime, our supreme court might feel free to act. However, the right of the clainiant is now controlled by the 1931 statute. The change should be made, but it will require action by the Wisconsin Legislature.

Campbell, Wiscoinsin Law Governing Automobile Accidents-Part II, 1962 Wis. L. REv. 557, 569 (emphasis added) (footnotes omitted). See also the dissenting opimion of Justice Ellis infra.

25. Plaintiff contends that the statute violates her right to meaningful access to judicial protection, that it unconstitutionally impairs her right to a jury trial, that it violates her substantive due process rights, and that it deprives her of her right to a remedy for her injury.

The "access to judicial protection" argunient is based on the due process clause of the fourteenth amendment to the United States Constitution and on article 1, section 1, of the Wisconsin constitution. The right of access to judicial protection, however, is at inost a right to be free from undue procedural impediments that prevent free access to the courts, not a right to a favorable substantive law resolution of the controversy in question. See text accompanying notes 38-39 infra. We therefore find plaintiff's argunent to be without merit.

The "jury trial" argument, which is based on article 1 , section 5 , of the Wisconsin constitution, also inust fail. In support of her argument, plaintiff urges that because a jury in Wisconsin is not told the effect of its allocation of fault under section 895.045 , Stats., see Kobelinski v. Milwaukce \& Suburban Transp. Corp., 56 Wis. 2d 504, 520, 202 N.W.2d 415, 425 (1972), the jury may be depriving a plaintiff of a diminished damage award when it believes and intends that the plaimtiff should recover in part, see Padway, Comparative Negligence, 16 MARQ. L. REv. 3, 21 (1931). But the right to a jury trial is a right to have the jury decide disputed issues of fact in the course of 
Stats., violates her right to equal protection of the laws, a right guaranteed by both the fourteenth aniendment to the United States Constitution and article 1 , section 1 , of the Wisconsin constitution. ${ }^{26}$ Plaintiff's equal protection contentions will be discussed in detail later. ${ }^{27}$ In essence, however, plaintiff claims that the statute impermissibly distinguishes, first, between a plaintiff who is nore than $50 \%$ neghgent and one who is $50 \%$ negligent or less, and, second, between a plaintiff who is more than $50 \%$ neghigent and an equally culpable defendant who,

applying the relevant law. At least in a civil case, the right does not require procedures that would permit, and perhaps encourage, jurors to disregard the judge's instructions and award a verdict on the basis of their own standards of "justice." Cf. United States v. Moylan, 417 F.2d 1002, 1005-07 (4th Cir. 1969) (although criminal jury has power to disregard law in deciding to acquit a defendant, jury should not be told that it has this power), cert. denied, 397 U.S. 910 (1970). A litigant is entitled to have the jury properly instructed on the law, but the jury need not know the effect of its application of the law. In McGowan v. Story, 70 Wis. 2d 189, 196-99, 234 N.W.2d 325, 328-30 (1975), we rejected a policy-based argument that we should overturu the court-made rule that precludes advising a jury of the effect of its determination of proportionate fault. Today the same argument comes dressed in constitutional garb, but the arguinent fares no better despite the change of attire.

Plaintiff's substantive due process argument, founded on the fourteenth amendinent to the United States Constitution and on article 1, section 1, of the Wisconsin constitution, parallels her equal protection claim. She inakes virtually the same points, first in the naine of equal protection, and then couched in terms of substantive due process. We do not criticize counsel for using both constitutional labels to describe plaintiff's objections to the statute. Each constitutional guarantee guards against similar legislative evils and therefore the two doctrines are integrally related. Nonetheless, we believe that this case clearly inplicates equal protection rather than substantive due process. When an aggrieved party coinplains that lie las received treatment different from that accorded others who are similarly situated, the issue is clearly one of equal protection. See Zablocki v. Redhail, 434 U.S. 374, 391-92, $395-96$ (1978) (Stewart, J., concurring in judginent); Ross v. Moffitt, 417 U.S. 600,609 (1974).

At oral argument, plaintiff for the first tine suggested that our comparative negligence statute violates the "right to a remedy" clause of article 1, section 9, of the Wisconsin constitution. Article 1, section 9, provides as follows:

Every person is entitled to a certain remedy in the laws for all injuries, or wrongs which he may receive in his person, property, or character, he ought to obtain justice freely, and without being obliged to purcliase it, completely and without denial, promptly and witlout delay, confonnably to the laws.

Plaintiff argues that, because she has suffered an injury to her person, this section entitles her to a remedy to the extent that the imjury was caused by the tortious conduct of another. Under existing precedent, this contention is wholly without merit. In fact, this court lias generally interpreted the "rigltt to a remedy" clause so narrowly as to render it virtually ineaningless. See Cords v. State, 62 Wis. 2d 42, 51, 214 N.W.2d 405, 410 (1974); Reistad v. Manz, 11 Wis. 2d 155, 159, 105 N.W.2d 324, 326 (1960) (Article 1, section 9, "Inerely guarantees a suitor a day in a court of competent jurisdiction to which he may present lis claim."). We question whetler these and other cases of similar import would be followed today, because they appear to ignore a constitutional provision that assuredly was designed to have vitality. However, in light of our resolution of plaintiff's equal protection claim, and because the issue was not briefed, we do not reacl the "right to a remedy" issue.

26. "[S]ec. 1, art. I, of the Wisconsin constitution is . . . substantially equivalent of the dueprocess and equal-protection clauses of the Fourteenth amendment to the United States constitution." State ex rel. Sonneborn v. Sylvester, 26 Wis. 2d 43, 49, 132 N.W.2d 249, 252 (1965).

27. See Part V. C. of this opinion infra. 
having discharged more than his proportionate share of a common hability to a plaimtiff, seeks contribution from his co-tortfeasors. ${ }^{28}$

\section{B. Standards to be Applied in Evaluating Plaintiff's Constitutional Contentions.}

Claims of denial of equal protection have been made in a vast array of contexts. 29 "Once loosed, the idea of Equahity is not easily cabined." Cox, The Supreme Court, 1965 Term-Foreword: Constitutional Adjudication and the Promotion of Human Rights, 80 Harv. L. Rev. 91, 91 (1966). The courts, in their continuing search for the limits of the guarantee of equal protection, have utilized varymg standards to test the validity of equal protection challenges. Because such challenges often imphicate both federal and state constitutional law, the process of identifying the standard or standards to be apphed is, in itself, a complex task. As a necessary precursor to our response to plamtiff's equal protection challenge, we move now to a consideration of the appropriate standards to be applied in this case under the Constitution of the United States and the Wisconsin constitution.

1. Federal Constitutional Law. The equal protection clause of the fourteenth amendment provides that no state shall "deny to any person within its jurisdiction the equal protection of the laws." U.S. Const. amend. XIV, $\S 1$. Although solne members of the Umited States Supreme Court have argued against the prevailing approach, ${ }^{30}$ the Court has recognized at least three distmct standards of equal protec-

28. We use the term "co-tortfeasors" to include "all cases where there is joint hability for a tort, whether the acts of those jointly liable were concerted, merely concurrent, or even successive in point of time." Leflar, Contribution and Indemnity Between Tortfeasors, 81 U. PA. L. REV. 130, 131 n.9 (1932).

29. See, e.g., Lalli v. Lalli, 439 U.S. 259 (1978) (illegitimacy); Duke Power Co. v. Carohna Environmental Study Group, Inc., 438 U.S. 59 (1978) (limitation on nuclear liability); Reed v. Reed, 404 U.S. 71 (1971) (sex); Shapiro v. Thompson, 394 U.S. 618 (1969) (interstate travel); Harper v. Virginia Bd. of Elections, 383 U.S. 663 (1966) (voting rights); Baker v. Carr, 369 U.S. 186 (1962) (legislative apportionment); McGowan v. Maryland, 366 U.S. 420 (1961) (Sunday closing law); Griffin v. Illinois, 351 U.S. 12 (1956) (criminal appeals); Brown v. Board of Educ., 347 U.S. 483 (1954) (race); State ex rel. Strykowski v. Wilkie, 81 Wis. 2d 491, 261 N.W.2d 434 (1978) (medical malpractice statutes); Hortonville Educ. Ass'n v. Hortonville Joint School Dist., 66 Wis. 2d 469, 225 N.W.2d 658 (1975) (discharge of striking school teachers), rev'd, 426 U.S. 482 (1976); Omernik v. State, 64 Wis. 2d 6, 218 N.W.2d 734 (1974) (categories of water use); Kmiec v. Town of Spider Lake, 60 Wis. 2d 640, 211 N.W.2d 471 (1973) (agricultural zoning).

30. See, e.g., Craig v. Boren, 429 U.S. 190, $211-12$ (1976) (Stevens, J., concurring) ("There is only one Equal Protection Clause. It requires every State to govern impartially. It does not direct the courts to apply one standard of review in some cases and a different standard in other cases."); Massachusetts Bd. of Retirement v. Murgia, 427 U.S. 307, 319 n.l (1976) (Marshall, J., dissenting) (advocating a "sliding scale" approach to equal protection analysis, in which the court would make "individualized assessments of the particular classes and rights involved in each case"). 
tion review. When a statute creates a classification based upon a "suspect" criterion such as race or national origin, ${ }^{31}$ or when the classification impinges upon a "fundamental imterest" such as the right to vote, ${ }^{32}$ the statute is tested under a rigorous, "strict scrutmy" standard. Laws measured by this test "are unconstitutional unless the State can demonstrate that such laws are 'necessary to promote a compelling governmental interest.'" Dunn v. Blumstein, 405 U.S. 330, 342 (1972) (emphasis in original) (quoting Shapiro v. Thompson, 394 U.S. 618, 634 (1969)). If neither a suspect class nor a fundamental interest is directly inplicated, a less demanding standard of review is apphed. For many years, at least in its langliage, the Supreine Court recognized only one standard of review less rigorous than strict scrutiny. Under this second test, the "rational basis" test, a statute is upheld agamst equal protection attack as long as its distinctions bear a rational relationship to some (perhaps even hypothetical) legitimate governmental purpose. See, e.g., McGowan v. Maryland, 366 U.S. 420, $425-26$ (1961); Williamson v. Lee Optical Co., 348 U.S. 483, 488-89 (1955); Goesaert v. Cleary, 335 U.S. 464, 466-67 (1948); Kotch v. Board of River Port Pilot Commissioners, 330 U.S. 552, 556 (1947). The selection of either the strict scrutiny or the rational basis standard of review is generally tantamount to a resolution of the constitutional claim itself. Professor Gunther has described the strict scrutimy test as " 'strict' in theory and fatal im fact," and the traditional rational basis test as one that entails "minimal scrutiny in theory and virtually none in fact." Gunther, The Supreme Court 1971 Term-Foreword: In Search of Evolving Doctrine on a Changing Court: A Model for a Newer Equal Protection, 86 Harv. L. Rev. 1, 8

31. See, e.g., Hunter v. Erickson, 393 U.S. 385, $391-92$ (1969) (race); Graham v. Richardson, 403 U.S. 365, 371-72 (1971) (national origin). A suspect criterion is one that singles out a class of persons "saddled with such disabilities, or subjected to such a history of purposeful unequal treatment, or relegated to such a position of political powerlessness as to coininand extraordinary protection from the majoritarian political process." San Antonio Independent School Dist. v. Rodriquez, 411 U S. 1, 28 (1973). A suspect class has also been claracterized as a class of persons that have "been subjected to unique disabilities on the basis of stereotyped characteristics not truly indicative of their abilities," Massachusetts Bd. of Retirement v. Murgia, 427 U.S. 307,313 (1976), and as a class of persons distinguishable by "an imınutable characteristic determined solely by the accident of birth" and generally bearing "no relation to ability to perform or contribute to society," Frontiero v. Richardson, 411 U.S. 677, 686 (1973) (plurality opimion).

32. Fundaunental interests are rights "explicitly or implicitly guaranteed by the Constitution." San Antonio Independent School Dist. v. Rodriquez, 411 U.S. at 33-34. Fundamental interests include the right to vote, see Harper v. Virginia Bd. of Elections, 383 U.S. 663, 670 (1966), the right to a criminal appeal, see Griffin v. lllinois, 351 U.S. 12, $17-19$ (1956), the right of interstate travel, see Shapiro v. Thompson, 394 U.S. 618, 629-31 (1969), and rights relating to procreation, see Skinner v. Oklahoina ex rel. Williamson, 316 U.S. 535, 541 (1942). The Supreme Court also has suggested that there may be a fundamental interest in access to the judicial process, see Boddie v. Connecticut, 401 U.S. 371,374 (1971), but the Court has severely limited the scope of any such fundamental right, see text accompanying notes 38-39 infra. 
(1972). ${ }^{33}$ Recently, however, a third standard of review-a review more meaningful than rational basis, but less rigorous than strict scrutiny-has emerged in certain contexts. ${ }^{34}$ This intermediate standard, although not always expressed in the same terms, ${ }^{35}$ calls for a serious judicial examination of the ends being pursued by the legislature, as well as the means chosen to further those ends. The cases in which this intermediate standard of review appears to be appropriate are those in which no suspect class or fundamental interest is directly involved, but in which the court is faced with some indicium of "suspectness,"36 or in which a fundamental interest is indirectly affected. ${ }^{37}$

Plaintiff contends that in the case at hand the fourteenth aunendment requires an application of strict scrutiny or-at a minimum-an intermediate standard of review. In support of this contention, plaintiff first argues that access to the courts is a fundamental interest, and that the right to such access includes the right to be free from unjustified substantive law discrimination between litigants who are similarly situ-

33. Professor Tribe has called strict scrutiny a "virtual death-blow" and rational basis review a "virtual rubber stamp." L. TRIBE, AMERICAN Constitutional LAw 1089 (1978). See also Dunn v. Blumstem, 405 U.S. 330, 363-64 (1972) (Burger, C.J., dissenting); Vance v. United States, 434 F. Supp. 826, 834 (N.D. Tex.), affd mem., 565 F.2d 1214 (5th Cir. 1977).

34. An intermediate standard is most clearly discernible when the challenged classification discrimmates on the basis of sex, see Craig v. Boren, 429 U.S. 190, 197 (1976), or illegitimacy, see Mathews v. Lucas, 427 U.S. 495, 509-10 (1976).

35. In the context of sex-based classifications, the test is clearly stated: "To withstand constitutional challenge, . . . classification by gender must serve important governmental objectives and must be substantially relatcd to achievement of those objectives." Craig v. Boren, 429 U.S. at 197. The Court has been less precise in the realm of illcgitimacy. In Mathews v. Lucas, 427 U.S. 495 (1976), the Court stated that its review of illegitimacy-based classifications is governed by a standard of "less than strict scrutiny," but that the appropriate test is "not a toothless one." Id. at 510. In Lalli v. Lalli, 439 U.S. 259 (1978) (plurality opinion), Justice Powell stated the appropriate standard as follows: "Although . . . classifications based on illegitimacy are not subject to "strict scrutimy,' they nevertheless are invalid under the Fourteenth Amendment if they are not substantially related to permissible state intcrests." Id. at 265.

36. For Supreine Court articulations of the indicia of "suspectness," see note 31 supra. Sex and illegitimacy fit neatly into a group of classes that might be called "semi-suspect." See Frontiero v. Richardson, 411 U.S. 677, 686 (1973) (A plurahty of four Justices was prepared to recognize sex as a suspect class, calling sex "an immutable characteristic determined solely by the accident of birth," and a characteristic that "frequently bears no relation to ability to perform or contribute to society."); Mathews v. Lucas, 427 U.S. at 505 ("It is true, of course, that the legal status of illegitimacy, however defined, is, like race or national origin, a characteristic determined by causes not within the control of the illegitimate individual, and it bears no relation to the individual's abikty to participate in and contribute to society."). One court has used the term "quasi-suspect" in referring to those classifications calling for an intermediate standard of review. Alma Soc'y Inc. v. Mellon, 601 F.2d 1225, 1233-34 (2d Cir. 1979).

37. Cf. Weber v. Aetna Cas. \& Sur. Co., 406 U.S. 164, 172 (1972) ("Though the latitude given state econounic and social regulation is necessarily broad, when state statutory classifications approach sensitive and fundamental personal rights, this Court exercises a stricter scrutiny . . . ."); Francis v. Cleland, 433 F. Supp. 605, 619 (D.S.D. 1977) (finding that intermediate standard is appropriate when the right affected is not fundamental, but is "close to fundamental"). 
ated. Plaintiff contends that our partial comparative negligence statute directly impinges upon this fundamental interest, and that a strict scrutiny review therefore is required. In the alternative, plaintiff argues that her fundainental interest in access to the courts is at least indirectly affected here, and that an intermediate standard of review therefore must be utilized. We disagree with both prongs of plaintiff's arguinent, because we do not believe that access to the courts, in the sense posited by plaintiff, is a fundamental interest for the purpose of equal protection analysis.

In Boddie v. Connecticut, 401 U.S. 371 (1971), the Supreme Court found that, "given the basic position of the marriage relationship in this society's hierarchy of values and the concomitant state monopolization of the ineans for legally dissolving this relationship, due process does prohibit a State from denying, solely because of inability to pay, access to its courts to individuals who seek judicial dissolution of their marriages." Id. at 374. Although Boddie was decided on due process grounds, plaintiff argues that Boddie stands for the proposition that access to the courts is a fundamental interest of constitutional dimension whenever there is no alternative to the judicial process for the resolution of the private legal claim in question. The Supreme Court, lowever, has refused to extend the Boddie ruling to other types of civil litigation, ${ }^{38}$ thus suggesting that the Court in Boddie was really protecting a fundamental interest in marital status, rather than access to the courts as such. ${ }^{39}$ More basically, however, any fundamental right to access merely would preclude undue procedural burdens preventing free access to the courts, especially burdens that disproportionately affect the indigent. Plaintiff's suggestion that sucl a right would imply a correlative fundamental right to favorable rules of substantive law, once the litigant had gained access to a judicial forum, is simply a non sequitur. In any event, sucl a doctrine would make all substantive law rights fundamental in a constitutional sense, because access to the courts is essential to give force to any substantive law riglit. Therefore, no equal protection challenge relating to substantive law riglits would be governed by the deferential rational basis test. This logical extension of plaintiff's argument reveals the inherent weakness of lier posi-

38. See Ortwein v. Schwab, 410 U.S. 656 (1973) (judicial review of denial of welfare benefits); United States v. Kras, 409 U.S. 434 (1973) (bankruptcy).

39. See Montgomery v. Daniels, 38 N.Y.2d 41, 60, 340 N.E.2d 444, 455-56, 378 N.Y.S.2d 1, 17 (1975). The Supreme Court clearly has recognized that the right to marry is fundamental. Zablocki v. Redhail, 434 U.S. 374, 383-86 (1978); cf. Loving v. Virginia, 388 U.S. 1 (1967) (miscegenation statute held unconstitutional with some reliance on the importance of marriage); Griswold v. Connecticut, 381 U.S. 479, 486 (1965) ("Marriage . . . is an association for as noble a purpose as any involved in our prior decisions."). 
tion. Every case involving substantive law rights in which the Supreme Court has applied the rational basis standard of review is authority for rejecting plaintiff's fundainental interest argument, because, were her argument valid, all such cases would demand more rigorous scrutiny.

Second, plaintiff argues that irrespective of whether a fundamental interest is present, the Supreme Court's recent decisions suggest that the Court is no longer willing to follow the rational basis test in its pristine form, and that the so-called "imtermediate" standard is in fact becoming the least demanding standard that the Court will apply. Plaintiff relies heavily on Professor Gunther's notable 1972 article, in which the author predicted the possible emergence of a "newer equal protection" standard adding "bite" to the traditional rational basis test. ${ }^{40}$ Supreme Court decisions, however, do not suggest that the traditional rational basis test has been abandoned. The Court has limited its stricter-than-usual, intermediate standard of review to cases approaching, though not quite reaclimg, the criteria necessary for invokmg strict scrutiny itself. ${ }^{41}$ ln cases that clearly concern notlimg more than the regulation of economic and social relationships, such as the case before us today, the Court continues to speak in the extremely deferential language that arose im the era of the Warren Court. In Holt Civic Club v. Tuscaloosa, 439 U.S. 60 (1978), for example, the Court quoted McGowan v. Maryland, 366 U.S. at 425, for the proposition that, when a stricter-than-usual scrutimy is not required, "the Equal Protection Clause is offended only if the statute's classification 'rests on grounds wholly irrelevant to the achievement of the State's objective.' " 439 U.S. at 71 . Indeed, the Court has recently applied the traditional rational basis test to a challenge not unlike the one being made in the instant case. In Duke Power Co. v. Carolina Environmental Study Group, Inc. 438 U.S. 59 (1978), the Court applied the traditional test in rejecting due process and equal protection challenges to a congressional limitation on the right to recover for mjuries sustamed as a result of nuclear mishaps. The Court explicitly rejected an intermediate standard of review. Id. at 83-84.42

40. Gunther, The Supreme Court 1971 Term-Foreword: In Search of Evolving Doctrine on a Changing Court: A Model for a Newer Equal Protection, 86 HARv. L. REv. 1, 18-20 (1972).

41. See notes 36-37 supra and accompanying text. But cf. Hawkins v. Superior Court, $22 \mathrm{Cal}$ 3d 584, 599, 586 P.2d 916, 926, 150 Cal. Rptr. 435, 445 (1978) (Mosk, J., concurring) (reading Zablocki v. Redhail, 434 U.S. 374 (1978), as a harbinger of a more general application of an intermediate standard of review).

42. The Supreme Court's recently heightened scrutiny under the Federal Constitution's contract clause might portend an increased degree of scrutiny for economic equal protection challenges. See United States Trust Co. v. New Jersey, 431 U.S. 1 (1977) (invalidating, on the basis of the contract clause, a legislative repeal of a statutory covenant providing security for bondholders). Such a development, however, has not yet occurred. Indeed, the Supreme Court's most 


\section{We have soine sympathy with plaintiff's contention that the ex-}

recent opinions suggest that no major change in the Court's approach to equal protection is in the offing.

In Illinois State Bd. of Elections v. Socialist Workers Party, 99 S. Ct. 983 (1979), the Court applied the strict scrutiny test to invalidate an election-related statute. See id. at 991 ("When such vital individual rights are at stake, a State must establish that its classification is necessary to serve a compelling interest."). The Court's language in Socialist Workers provoked Justice Blackinun to express his

unrelieved discomfort with what seems to be a continuing tendency in this Court to use as tests such easy phrases as "compelling state interest" and "least drastic [or restrictive] ineans". . . I have never been able fully to appreciate just what a "compelling state interest" is. if it means "convincingly controlling," or "incapable of being overcoine" upon any balancing process, then, of course, the test merely announces an inevitable result, and the test is no test at all.

Id. at 993 (Blackmun, J., concurring).

In Vance v. Bradley, 99 S. Ct. 939 (1979), the Court upheld a statutory distinction between Foreign Service employees over age 60 and other federal personnel over that age, applying the rational basis test. See id. at 943 ("[W] will not overturn [a statute not burdening a suspect group or a fundamental interest] unless the varying treatment of different groups or persons is so unrelated to the achievement of any combination of legitinate purposes that we can only conclude that the legislature's actions wcre irrational."); $i d$. at 950 ("In an equal protection case of this type .... those challenging the legislative judgment must convince the court that the legislative facts on which the classification is apparently based could not reasonably be conceived to be true by the governmental decisionmaker."). Only Justice Marshall, who urged an intermediate standard of review such as that applied to sex-based classifications, dissented from what Marshall called "the glancing oversight of the rational basis test . . . . /d. at 952 (Marshall, J., dissenting). In Friedman v. Rogers, 99 S. Ct. 887 (1979), the Court upheld a ban on the practice of optometry under a trade name in the face of first amendinent and equal protection arguments. All nine Justices concurred in the Court's equal protection analysis, which found the traditional rational basis test to be appropriate. See id. at 898; id. at 899 (Blackmun, J., concurring in part and dissenting in part). For still other recent cases applying the rational basis test to reject equal protection challenges, see Barry v. Barchi, 99 S. Ct. 2642 (1979); New York City Transit Auth. v. Beazer, 99 S. Ct. 1355 (1979).

The Court also has adhered to its limited application of an intermediate standard of review. In Orr v. Orr, $99 \mathrm{~S}$. Ct. 1102 (1979), the Court applied its previously adopted standard for sexbased classifications. Id. at 1111 ("[C]lassifications by gender inust serve important governmental objectives and must be substantially related to achievement of those objectives.") (citation omitted). The Court found this standard violated by a statutory scheme providing that husbands, but not wives, could be required to pay alinony upon divorce. Id. at 1111-14. The Court applied the same test to invalidate gender-based classifications in Califano v. Westcott, $99 \mathrm{~S}$. Ct. 2655 (1979), and in Caban v. Mohainmed, 99 S. Ct. 1760 (1979). Also dealing with a sex-based classification was Parham v. Hughes, 99 S. Ct. 1742 (1979), in which the Court upheld a statute allowing a wrongful death recovery by the mother of a deceased illegitinate child, but generally prohibiting such a recovery by the father. In a curiously reasoned plurality opinion, representing the views of four members of the Court, Justice Stewart first exainined the propriety of the gender-based classification and, having determined that the classification furthered appropriate legislative policies, then decided that the rational basis test should be applied to this sort of inoffensive sex-based classification. See id. at 1748. Having perceived the plurality's non sequitur, Justice Powell, concurring in the result, applied the appropriate intermediate standard of review in order to reach, in a direct manner, the same result reached by the plurality through its circuitous reasoning. See $i d$. at 1750 (Powell, J., concurring in judginent). The four dissenting justices agreed with Justice Powell that the intermediate standard of review was called for, see id. at 1751 (White, J., dissenting), although they differed with Powell on whether the statute passed muster under this test. Thus, a majority of the Court (Justice Powell plus the four dissenters) continue to find that the 
treme judicial deference evidenced by the traditional rational basis test represents an abdication of the judiciary's responsibility in a governmental system of checks and balances. But we do not sit as the highest court in the land, and we are bound by the dictates of the United States Supreme Court concerning matters of federal constitutional law. Accordingly, we find that under the fourteenth amendment to the United States Constitution, section 895.045, Stats., must withstand only the lenient, rational basis standard of review.

Under this standard of review, the challenger bears a heavy, if not insurnountable, ${ }^{43}$ burden. "In an equal protection case of this type ...., those challenging the legislative judgment must convince the court that the legislative facts on which the classification is apparently based could not reasonably be conceived to be true by the governmental decisionmaker." Vance v. Bradley, 99 S. Ct. 939, 950 (1979). The classification will not be overturned unless "the varymg treatment of different groups or persons is so unrelated to the achievement of any combination of legitimate purposes that [the court] can only conclude that the legislature's actions were irrational." Id. at 943.

[T]he Fourteenth Amendment permits the States a wide scope of discretion in enacting laws which affect some groups of citizens differently than others. The constitutional safeguard is offended only if the classification rests on grounds wholly irrelevant to the achievement of the State's objective. State legislatures are presumed to have aeted within their constitutional power despite the fact that, in practice, their laws result in some inequahity. A statutory discrimmation will not be set aside if any state of facts reasonably may be conceived to justify it.

McGowan v. Maryland, 366 U.S. at 425-26. "Legislatures are presumed to have acted constitutionally . . . , and their statutory classifications will be set aside only if no grounds can be conceived to justify them." McDonald v. Board of Election Commissioners, 394 U.S. 802, 809 (1969).

intermediate standard should be used in judging any sex-based classification. $C f$. Personnel Adm'r v. Feeney, 99 S. Ct. 2282 (1979) (finding veterans' preference not to be gender-based classification, and therefore finding intermediate standard of review inapplicable).

43. There is one case decided since the mid-1930s, Morey v. Doud, 354 U.S. 457 (1957), in which the Supreme Court did invalidate an exclusively economic regulation on equal protection grounds. But Morey subsequently was overruled as a case departing "froin proper equal protection analysis in cases of exclusively economic regulation." City of New Orleans v. Dukes, 427 U.S. 297, 306 (1976). The Court in Dukes stated categorically that "this Court consistently defers to legislative determinations as to the desirability of particular statutory discriminations [in the sphere of economic regulation]." Id. at 303. One court has described the judicial function under the rational basis standard in this way: "In other words, hands off." Vance v. United States, 434 F. Supp. 826, 834 (N.D. Tex.), aff'd mem., 565 F.2d 1214 (5th Cir. 1977). 
2. Wisconsin Constitutional Law. Article 1, section 1, of the Wisconsin constitution has been held to embody a guarantee of equal protection of the laws. ${ }^{44}$ Although our past cases have not always indicated when we were relying on the Wisconsin constitution, as opposed to the United States Constitution, it nonetheless is clear that in the area of equal protection our state constitution possesses an independent vitality.

"[S]tate courts cannot rest when they have afforded their citizens the full protections of the federal Constitution. State constitutions, too, are a font of individual liberties, their protections often extending beyond those required by the Supreme Court's imterpretation of federal law." Brennan, State Constitutions and the Protection of Individual Rights, 90 Harv. L. Rev. 489, 491 (1977).45 Only recently, citing Mr. Justice Brennan's article, we said:

Certainly, it is the prerogative of the State of Wisconsin to afford greater protection to the liberties of persons within its boundaries under the Wisconsin Constitution than is mandated by the United States Supreme Court under the Fourteenth Amendment. . . . This court has never hesitated to do so.

This court has demonstrated that it will not be bound by the minimums which are imposed by the Supreme Court of the United States if it is the judgment of this court that the Constitution of Wisconsin and the laws of this state require that greater protection of citizens' liberties ought to be afforded.

State v. Doe, 78 Wis. 2d 161, 171-72, 254 N.W.2d 210, 215-16 (1977). Although this language from Doe arose im the context of criminal procedure, we believe that the principle is equally applicable here. ${ }^{46}$

\footnotetext{
44. See note 26 supra.

45. Mr. Justice Marshall also has encouraged state courts to use their state constitutions to recognize constitutional standards more protective of citizens than the standards used by the United States Supreme Court in its interpretations of the Federal Constitution. See Oregon v. Mathiason, 429 U.S. 492, 499 (1977) (Marshall, J., dissenting) ("It is . . important to note that the state courts remain free, in interpreting state constitutions, to guard against the evil clearly identified by this case.") (footnote omitted). The California Supreme Court has been more willing than most state supreme courts to raise its state constitutional standards above the federal constitutional floor. See Serrano v. Priest, 18 Cal. 3d 728, 764, 557 P.2d 929, 950, 135 Cal. Rptr. 345, 366 (1976) ("[O]ur state equal protection provisions . . . are possessed of an independent vitality which, in a given case, may demand an analysis different from that which would obtain if only the federal standard were applicable."), cert. denied, 432 U.S. 907 (1977); People v. Disbrow, 16 Cal. 3d 101, 114-15, 545 P.2d 272, 280, 127 Cal. Rptr. 360, 368-69 (1976) ("We . . reaffirm the independent nature of the California Constitution and our responsibility to separately define and protect the rights of California citizens despite conflicting decisions of the United States Supreme Court interpreting the federal Constitution."). See generally Howard, State Courts and Constitutional Rights in the Day of the Burger Court, 62 VA. L. REv. 873 (1976).

46. See Nehring v. Russell, 582 P.2d 67, 76-77 (Wyo. 1978); cf. Montgomery v. Daniels, 38 N.Y.2d 41, 71, 340 N.E.2d 444, 463, 378 N.Y.S.2d 1, 27 (1975) (Fuchsberg, J., concurring) (expres-
} 
In all candor, we must admit that this court's approach to equal protection has not been a model of clarity and consistency. In many cases, we have suggested that the equal protection guarantees of the Wisconsin and Federal Constitutions are identical in scope..$^{47}$ We have cited United States Supreine Court decisions and those of our own court interchangeably, without regard to which constitution was involved. ${ }^{48}$ Indeed, much of the language from our decisions would suggest that the instant case should be decided under a standard of review at least as deferential as that which we have found to be controlling under federal law. For example, we have stated the rule as follows: "Absent a suspect classification or a fundamental right . . . [, ] . . to declare an act of the legislature as to a classification violative of the equal protection clause, it is first necessary to prove that the legislature has abused its discretion beyond a reasonable doubt." "Hortonville Education Association v. Hortonville Joint School District No. 1, 66 Wis. 2d 469, 483, 225 N.W.2d 658, 665-66 (1975) (quoting State ex rel. LaFollette v. Reuter, 36 Wis. 2d 96, 111, 153 N.W.2d 49, 55 (1967)), rev'd on other grounds, 426 U.S. 482 (1976). We also have said that when strict scrutiny is not appropriate, the decision concerning statutory classifications "is one resting primarily with the legislature and no court is justified in declaring such a determmation baseless or unconstitutional unless it can be said without doubt that no one could reasonably conclude there is any substantial reason justifying different legislative treatment." State v. Duffy, 54 Wis. 2d 61, 66, 194 N.W.2d 624, 627 (1972). We have added that, when such a standard of review is applied, "[t]he court cannot reweigh the facts as found by the legislature. If the court can conceive any facts on which the legislation could reasonably be based, it must hold the legislation constitutional." State ex rel. Strykowski v. Wilkie, 81 Wis. 2d 491, 506, 261 N.W.2d 434, 441 (1978). ${ }^{49}$

sing dissatisfaction with the Federal Constitution rational basis test "when serious and very basic consequences to individuals are involved, even when those consequences can be labeled economic") (citations omitted); Hetherington, State Economic Regulation and Substantive Due Process of Law, 53 Nw. U.L. REv. 226, 250 (1958) ("[S]tate courts may be in a better position to review local economic legislation than the Supreme Court. State courts, since their precedents are not of national authority, may better adapt their decisions to local economic conditions and needs.").

47. E.g., State ex rel. Fort Howard Paper Co. v. State Lake Dist. Bd. of Review, 82 Wis. 2d 491, 511 n.10, 263 N.W.2d 178, 188 n.10 (1978); Kallas Millwork Corp. v. Square D Co., 66 Wis. 2d 382, 388, 225 N.W.2d 454, 458 (1975); State ex rel. Hammermill Paper Co. v. La Plante, 58 Wis. 2d 32, 73-74, 205 N.W.2d 784, 807-08 (1973); State ex rel. Sonneborn v. Sylvester, 26 Wis. 2d 43, 49, 132 N.W.2d 249, 252 (1965).

48. E.g., State ex rel. Strykowski v. Wilkie, 81 Wis. 2 d 491, 506-10, 261 N.W.2d 434, 441-42 (1978); Harris v. Kelley, 70 Wis. 2d 242, 251-55, 234 N.W.2d 628, 632-33 (1975); State v. Duffy, 54 Wis. 2d 61, 65-66, 194 N.W.2d 624, 626 (1972).

49. In State ex rel. Hamınernill Paper Co. v. La Plante, 58 Wis. 2d 32, 205 N.W.2d 784 
Notwithstanding such extremely deferential language, this court, in reviewing legislative classifications that lave not in any way implicated suspect classes or fundamental rights, has not hesitated to strike down legislation that did not realistically serve a meaningful legislative end. ${ }^{50}$ Most of the legislation we have invalidated in the course of our purported applications of the rational basis test almost surely would have been upheld by the United States Supreme Court. ${ }^{51}$ In many instances our review, unlike that of the Supreme Court, has not consisted of "minimal scrutiny in theory and virtually none in fact." 52 In at least some of our cases, we clearly have applied, sub silentio, a test more demanding than that which the United States Supreme Court would have applied under the Federal Constitution. To the extent we have relied on the Federal Constitution in these prior decisions, such reliance was undoubtedly misplaced. In fulfillment of our role as the ultimate overseer of the rights and obligations embodied in the Wisconsin constitution, however, this court can legitimately apply a more stringent standard. ${ }^{53}$

(1973), we said that "[e]very presumption must be indulged to sustain the law if at all possible ...." Id. at 46, 205 N.W.2d at 792. In Madison Metropolitan Sewerage Dist. v. Committee on Water Pollution, 260 Wis. 229, 50 N.W.2d 424 (1951), we stated that all that is required to avoid an equal protection violation is that there "be soine reasonable basis along general lines for the adoption, all reasonable doubts to be resolved in favor thereof and when this is found the judicial function ends and the legislative function begins." Id. at 253,50 N.W.2d at 437 . For other statements of a deferential standard of review, see Kallas Millwork Corp. v. Square D Co., 66 Wis. 2d 382, 388, 225 N.W.2d 454, 458 (1975); Cords v. State, 62 Wis. 2d 42, 51-52, 214 N.W.2d 405, 41011 (1974); County of Dane v. McManus, 55 Wis. 2d 413, 422-23, 198 N.W.2d 667, 672 (1972); Town of Vanden Broek v. Reitz, 53 Wis. 2d 87, 92-93, 191 N.W.2d 913, 916 (1971), appeal dismissed, 406 U.S. 902 (1972); State ex rel. La Follette v. Reuter, 36 Wis. 2d 96, 109-11, 153 N.W.2d 49, 55 (1967).

50. See, e.g., State v. Asfoor, 75 Wis. $2 d 411,249$ N.W.2d 529 (1977) (invalidating statutory distinction making homicide by negligent use of weapon or vehicle a misdemeanor, but unaking crime of causing imjury short of deatl by negligent use of weapon a felony); Kallas Millwork Corp. v. Square D Co., 66 Wis. 2d 382, 225 N.W.2d 454 (1975) (invalidating statute of limitations benefiting certain persons making improvements on real property, but not others); Kmiec v. Town of Spider Lake, 60 Wis. 2d 640, 211 N.W.2d 471 (1973) (invalidating agricultural zoning classification that gave land a substantial negative value); State ex rel. O'Neil v. Town of Hallie, 19 Wis. $2 \mathrm{~d}$ 558,120 N.W.2d 641 (1963) (invalidating administrative refusal to license one outdoor theater while a similar theater remaimed liceused); Brennan v. City of Milwaukee, 265 Wis. 52, 60 N.W.2d 704 (1953) (invalidating ordinance that required installation of bathrooin or shower in apartments with more than three rooms, but not in those with three rooms or lcss).

51. See Part V.B.1. of this opinion supra.

52. Gunther, supra note 40 , at 8.

53. In Johnson v. Hassett, 217 N.W.2d 771 (N.D. 1974), the North Dakota Supreme Court invalidated that state's guest statute, relying exclusively on the North Dakota constitution. The court compared its own constitutional adjudications witl those of the United States Supreme Court:

While some of our decisions would pass muster under the "inherently suspect" criteria . . . and others under the "traditional" equal-protection analysis . . . , it may be that some of our statutes which we have declared unconstitutional might lave passed the 
We have no occasion today to delineate fully the circumstances in which our standard of review should be more searching than that required under the Federal Constitution. ${ }^{54}$ We believe, however, that in inaking such determinations, our primary concerns should be the nature and importance of the individual interests adversely affected by the legislative classification and our competence as judges to deal with the subject matter of the classification in question.

In the present case, the challenged classification adversely affects the interest of contributorily negligent plaimtiffs in receiving recompense for injuries caused in part by the tortious conduct of others. Although this interest is not as important as certain individual interests, ${ }^{55}$ we beheve that it is of sufficient magnitude to inerit significant constitutional protection. There is a basic policy, deeply engramed in the tradition of the law and in the expectations of society, that persons injured by the tortious conduct of others are entitled to compensation. ${ }^{56}$ What is involved is a right "not only of monetary value but in many cases fundamental to the injured person's physical well-being and ability to continue to live a decent life." Hunter v. North Mason High School, 85 Wash. 2d 810, 814, 539 P.2d 845, 848 (1975).

Also relevant is our competence as state court judges to evaluate the classification. The law of torts is, im large part, a creation of the courts. Other areas of the law nuay require technical analysis and in-

\footnotetext{
Federal constitutional screening. Such results are to be expected under a dual constitutional system. The Federal courts examme State statutes only to determine if they comply with the United States constitutional mandates ... ; we examine them for that purpose and also to determine if they comply with State constitutional mandates. ... No one should be surprised if a statute passes the one set of standards and not the other. Id. at 776 .

54. Our standard of review can never be less searching than that required under the Federal Constitution. Thus, in dealing with a classification that requires strict scrutimy or an intermediate standard of review under the Federal Constitution, we are required to examine the challenged statute with a scrutiny at least as exacting as the relevant federal standard requires. See generally U.S. Const. art. Vl, cl. 2. But cf. Hawkins v. Superior Court, 22 Cal. 3d 584, 595-607, 586 P.2d 916, 923-31, 150 Cal. Rptr. 435, $442-50$ (1978) (After writing the inajority opinion, holding that strict scrutiny is required under traditional equal protection law, Justice Mosk also wrote a separate concurring opinion, calling for an intermediate standard of review.). Our present discussion concerns cases in which the Federal Constitution would require only a rational basis standard of review, but to which we are free to apply a more demanding standard under the Wisconsin constitution.

55. Few would deny that this interest in compensation is less weighty than, for example, interests relating to political freedoins or to the procedural rights of a defendant in a crinnmal case. But of. Hetherington, supra note 46, at 248 ("From a practical standpoint, [economic rights are] . . . as iniportant, and as deserving of protection, as are first annendment rights.").

56. See Cooper v. Bray, 21 Cal. 3d 841, 854, 582 P.2d 604, 612, 148 Cal. Rptr. 148, 156 (1978). "The right to be fully compeusated for tortiously inflicted injuries is recognized as being of vital importance to the injured party and society." Note, California's Medical Injury Compensation Reform Act: An Equal Protection Challenge, 52 S. CAL. L. Rev. 829, 936 (1979) (footnote omitted).
} 
depth investigation through the elaborate mechanisms available to the legislature but not to us. But courts have proven their ability to develop tort law doctrines and, through the process of developing such common law rules, have gained a special experience and conipetence in the area. Judges are, therefore, uniquely qualified to assess equal protection challenges to existimg tort doctrines. Accordingly, when important individual interests falling within the realm of tort law are adversely affected by legislative classifications, our special insights require that the standard by which we evaluate equal protection challenges to such classifications be more meaningful than the standard called for by the traditional rational basis test. As one writer has observed:

[W] hatever the merit of the anti-activist posture [of the courts] with regard to constitutional adjudication of economic regulatory legislation under the equal protection and due process clauses, it has hittle relevance to tort law. . . . Traditional attacks upon judicial activism . . . are overbroad when applied to tort law. Tort law is, and historically has been, an area predominately developed and cultivated by the courts.

Comment, Judicial Activism in Tort Reform: The Guest Statute Exemplar and a Proposal for Comparative Negligence, 21 U.C.L.A. L. Rev. 1566,1590 (1974) (footnote omitted)..$^{57}$

We are by no means the first court to apply an equal protection standard more stringent than the traditional rational basis test in the case of a challenged classification growing out of tort law. In Brown $v$. Merlo, 8 Cal. 3d 855, 506 P.2d 212, 106 Cal. Rptr. 388 (1973), the California Supreme Court invalidated that state's basic guest statute, ${ }^{58}$ ap-

57. For views sympathetic to judicial lawmaking in the field of torts, see Fleming, supra note 10, at 273-82; Keeton, supra note H. Cf. Hoffman v. Jones, 280 So. 2d 431, 434 (Fla. 1973) (judicially adopting a rule of pure comparative negligence: "The rule that contributory negligence is an absolute bar to recovery was-as most tort law-a judicial creation."). For contrasting views concerning the propriety of judicial activism generally, compare Perry, Abortion, the Public Morals, and the Police Power: The Ethical Function of Substantive Due Process, 23 U.C.L.A. L. REv. 689 (1976) with Ely, The Wages of Crying Wolf: A Comment on Roe v. Wade, 82 YALE L.J. 920 (1973).

58. A related California statute, limiting owner-passengers to the same sort of restricted cause of action as that available to guests under a basic guest statute, has been invalidated, upleeld, and invalidated again by the California Supreme Court, all within the space of three and a lialf years. Justice Tobriner explained it this way in the court's most recent opmion on the issue:

In April 1975, our court mitially concluded in Schwalbe v. Jones (1975) 120 Cal. Rptr. 585, 534 P.2d 73, that this statutory provision violated the constitutional equal protection guarantee. Thereafter, lowever, we granted a reliearing in Schwalbe and, upon rehearing, a majority of the court sustamed the statute against constitutional challenge. (Schwalbe v. Jones (1976) 16 Cal.3d 514, 128 Cal. Rptr. 321, 546 P.2d 1033.) After a careful reexamination of the issue, we lave concluded that our origimal constitutional deternmimation was correct and that, under the appropriate governing equal protection standard, the disparate treatment mandated by section 17158 cannot be constitutionally sustained. 
plying an intermediate standard of review under which a discriminatory classification is upheld only if it "substantially" furthers a state purpose that is not "unrealistic." 59 Similarly, the Michigan Supreme Court imvalidated tlie Michigan guest statute under an intermediate equal protection standard described by the court as the "substantial-relation-to-the-object test." Manistee Bank \& Trust Co. v. McGowan, 394 Micli. 655, 671, 232 N.W.2d 636, 642 (1976). In addition to California and Michigan, a number of otler states have held their guest statutes unconstitutional on equal protection grounds. ${ }^{60} \mathrm{In}$ asmucl as controlling federal law, under whicls the traditional rational basis test would be applicable, finds guest statutes inoffensive to the equal protection clause, ${ }^{61}$ these state court decisions are defensible only as cases decided on tlie basis of state constitutional law under a stan-

Cooper v. Bray, 21 Cal. 3d 841, 844, 582 P.2d 604, 605, 148 Cal. Rptr. 148, 149 (1978).

59. 8 Cal. 3d at 865 \& n.7, 506 P.2d at 219 \& n.7, 106 Cal. Rptr. at 395 \& n.7. See Comment, Judicial Activism in Tort Reform: The Guest Statute Exemplar and a Proposal for Comparative Negligence, 21 U.C.L.A. L. REv. 1566, 1567-68 (1974).

60. Guest statutes have been invalidated in 10 states: California, Brown v. Merlo, $8 \mathrm{Cal} .3 \mathrm{~d}$ 855, 506 P.2d 212, 106 Cal. Rptr. 388 (1973); Idaho, Thompson v. Hagan, 96 Idaho 19, 523 P.2d 1365 (1974); Kansas, Henry v. Bauder, 213 Kan. 751, 518 P.2d 362 (1974); Michigan, Manistee Bank \& Trust Co. v. McGowan, 394 Micl. 655, 232 N.W.2d 636 (1975); Nevada, Laakonen v. Eighth Judicial Dist. Court, 91 Nev. 506, 538 P.2d 574 (1975); New Mexico, McGeehan v. Bunch, 88 N.M. 308, 540 P.2d 238 (1975); North Dakota, Johnson v. Hassett, 217 N.W.2d 771 (N.D. 1974); Ohio, Primes v. Tyler, 43 Ohio St. 2d 195, 331 N.E.2d 723 (1975); South Carolina, Ramey v. Raney, 48 U.S.L.W. 2282 (S.C. Oct. 23, 1979); and Wyoming, Nehring v. Russell, 582 P.2d 67 (Wyo. 1978). Other states' guest statutes have survived constitutional attack. For a review of the various decisions deahing with the constitutionahty of guest statutes, see Annot., 66 A.L.R.3d 532 (1975). More than ten years before the seminal guest statute invalidation in Brown v. Merlo, 8 Cal. 3d 855, 506 P.2d 212, 106 Cal. Rptr. 388 (1973), see text accompanying notes 58-59 supra, this court abandoned Wisconsin's guest doctrine, whicl liad been judicially created. McConville v. State Farin Mut. Auto. Ins. Co., 15 Wis. 2d 374, 113 N.W.2d 14 (1962). We abandoned the doctrine on the basis of a change in the common law, happily avoiding the need to subject the courtmade doctrine to constitutional scrutiny. But see Comment, Testing the Constitutionality of Medical Malpractice Legislation: The Wisconsin Medical Malpractice Act of 1975, 1977 WIS. L. REv. 838, 871-72 ("TT]he Wisconsin Supreme Court abandoned the judicially created guest law in $M c$ Conville ... , apparently on equal protection grounds. . . Mc Conville stands for the proposition that injured guest passengers are, for equal protection purposes, indistinguishable from injured nonguest passengers.") (footnote omitted).

61. In Silver v. Silver, 280 U.S. 117 (1929), the Supreme Court sustamed a guest statute in the face of an equal protection attack. Although Silver was decided fifty years ago, it almost certainly would be decided the same way today. In three recent cases, the Supreme Court lias dismissed, for want of a substantial federal question, appeals challenging the constitutionahity of guest statutes. White v. Hughes, 257 Ark. 627, 519 S.W.2d 70, appeal dismissed, 423 U.S. 805 (1975); Hill v. Garner, 277 Or. 641, 561 P.2d 1016, appeal dismissed, 434 U.S. 989 (1977); Cannon v. Oviatt, 520 P.2d 883 (Utah), appeal dismissed, 419 U.S. 810 (1974). Such dismissals for want of a substantial federal question constitute adjudications on the merits and have precedential value. Hicks v. Miranda, 422 U.S. 332, 343-45 (1974). See Neu v. Grant, 548 F.2d 281 (10th Cir. 1977) (sustaining the constitutionahity of the Wyoming guest statute on the strength of Silver and Cannon); Sidle v. Majors, 536 F.2d 1156 (7th Cir.) (reluctantly sustaining the constitutionahity of the Indiana guest statute on the strength of Silver and Cannon), cert. denied, 429 U.S. 945 (1976). 
dard of review more stringent than the traditional rational basis test. ${ }^{62}$ Although the guest statute cases provide the most notable instances of serious equal protection inquiry in the field of tort law, there are other examples as well. ${ }^{63}$ It is significant that the statutes being tested in all of these cases fell within the province of tort law. In our opinion, this fact both explains and justifies the ineaningful constitutional inquiries undertaken in these cases. ${ }^{64}$

62. Admittedly, some of the courts invalidating guest statutes have purported to apply the deferential rational basis test. But these courts have in fact honed a sharper edge to their equal protection analysis than the traditional standard of review would allow. See Comment, Equal Protection Challenges 10 Automobile Guest Statutes, 8 CREIGHTON L. Rev. 432, $446-47$ (1974). It also is true that some courts, including the Cahifornia Supreme Court im Brown v. Merlo, 8 Cal. 3d 855, 506 P.2d 212, 106 Cal. Rptr. 388 (1973), have invoked the Federal Constitution as at least an alternative ground for striking down guest statutes. Given the present tenor of Supreme Court decisions, however, we believe that any reliance on the federal equal protection clause is misplaced. See note 61 supra; Part V.B.1. of this opmion supra. See Johnson v. Hassett, 217 N.W.2d 771,780 (N.D. 1974) (In finding the North Dakota guest statute violative of the state but not the Federal Constitution, the North Dakota Supreme Court noted that the federal courts miglit find that the statute meets "minimum Federal standards, as they did in Silver v. Silver . . . To this extent we disagree with Brown v. Merlo, . . . which held that the California statute violated both Federal and State Constitutions.") (citations omitted); Nehring v. Russell, 582 P.2d 67, 76 (Wyo. 1978) (In finding the Wyoming guest statute not violative of the Federal Constitution, the Wyoining Supreme Court referred to White, Cannon, and Sidle, see note 61 supra, as follows: "[B]ased on [these] federal authorities, they being the strongest indication of federal constitutional intent, we must hold that the Wyoming guest statute does not violate the equal protection guarantees of the Fourteenth Amendment, United States Constitution. We prefer not to ignore tlie most eminent authority available on federal constitutional questions, and there is no reason why we should." The court went on to find the guest statute violative of the Wyoming state constitution.).

63. E.g., Muzar v. Metro Town Houses, Inc., 82 Mich. App. 368, 266 N.W.2d 850 (1978) (invalidating, under an intermediate standard of review, a statute of limitations provision applicable to tort suits agamst architects and engineers, but not to similar suits against others im the construction industry); Arneson v. Olson, 270 N.W.2d 125, 132-33 (N.D. 1978) (invalidating medical malpractice provisions under an intermediate standard of review); Moyer v. Phillips, $462 \mathrm{~Pa}$. 395, 400-01, 341 A.2d 441, 443 (1975) (invalidating, under an internediate standard of review, statutory exception for libel and slander actions from the general rule that causes of action survive the death of the plaimtiff or defendant).

A student Note has suggested that several recent state court invalidations of medical inalpractice legislation, even if not expressly grounded on an intermediate equal protection review, are in fact explicable on that basis. See Note, supra note 56, at 866-80. The authors contend that an intermediate standard is appropriate "especially . . . when 'important,' although not necessarily 'fundamental' rights are at stake." Id. at 894 (footnote ounitted).

It could be argued that decisions such as those in the guest statute and medical inalpractice cases are not relevant authority for heiglitened judicial scrutiny in the instant tort case. In the guest statute and medical malpractice cases, courts were faced with legislative contractions of the liability that otherwise would exist at cominon law, while we deal here with a legislative liberalization of a harsh common law rule that otherwise would bar recovery altogether. We believe, lowever, that the fact that we are dealing with a liberalization of conmon law recovery is relevant, if at all, only as a possible reason for extending the period of judicial restramt that appropriately follows experimental legislative actions. In the present case, as we discuss in Part V.C.3. of this opinion infra, the time for experimentation clearly las run its course.

64. Perliaps every equal protection cliallenge, regardless of its subject inatter, deserves inore than a perfunctory review under the traditional rational basis test. See, e.g., Newland v. Board of 
In articulating the intermediate standard of review to be applied in judging the statute challenged in this case, we einploy no magic linguistic formula ${ }^{65}$ that can be used to test this or any other statute in a hitmus-paper fashion. What we require is that a statute tested under this standard of review reahistically further a legitimate and meaningful legislative end. ${ }^{66}$ This standard of review calls for considerable deference to legislative judgments, particularly factual judgınents based on legislative investigations and proceedings. At the saine time, it imposes upon the court an obligation to assess in a serious and careful manner both the legislative ends pursued and the degree to which the statute effectuates those ends. Although the court inust be generous in its regard for the collective legislative wisdom, such generosity should be tempered by an abiding sense of realisin responsive to the practicalities of the day.

In 1904, this court, relying on precedent dating back well into the last century, stated:

The essentials of a constitutional classification have been stated over and over again. They were given in the form of rules in Johnson v. Milwaukee, thus: (1) All classification nust be based upon substantial distinctions which make one class really different from another. (2) The classification adopted must be germane to the purpose of the law. (3) The classification must not be based upon existing

Governors, 19 Cal. 3d 705, 711, 566 P.2d 254, 258, 139 Cal. Rptr. 620, 624 (1977) ("All of the formulas [for equal protection review] require the court to conduct 'a serious and genuine judicial inquiry into the correspondence between the classification and the legislative goals." ") (citation oinitted); lsakson v. Rickey, 550 P.2d 359 (Alaska 1976). In Isakson the court stated that in order for a classification to survive judicial scrutiny, the classification "must be reasonable, not arbitrary, and must rest upon some ground of difference having a fair and substantial relation to the object of the legislation, so that all persons similarly circumstanced shall be treated alike."

It is this more flexible and more demanding standard which will be applied in future cases if the compelling state mterest test is found inappropriate. As a result, we will no longer hypothesize facts which would sustain otherwise questionable legislation as was the case under the traditional rational basis standard. . . .

Legislative leeway for unexplained pragmatic experimentation is substantially narrowed.

This new standard will, in short, close the wide gap between the two tiers of equal protcction by raising the level of the lower tier from virtual abdication to genuine judicial imquiry.

Id. at 362-63 (footnote and citations omitted).

65. [Polonius:] . . . What do you read, iny lord?

[Hamlet:] Words, words, words.

W. Shakespeare, Hamlet, Prince of Denmark, Act II, Scene II. We give credit to a student cominentator for calling our attention to this quotation from Shakespeare. Comment, The Ohio Guest Statute, 22 OHro ST. L.J. 629, 637 (1961). Cf. Carter v. Carter Coal Co., 298 U.S. 238, 327 (1936) (Cardozo, J., dissenting in part and concurring in result $\mathrm{m}$ part) ("But a great principle of constitutional law is not susceptible of comprehensive statement in an adjective.").

66. Cf. Police Dep't v. Mosley, 408 U.S. 92, 95 (1972) ("[T]he crucial question is whether there is an appropriate governmental imterest suitably furthered by the differential treatment."). 
circumstances only; it must not be so constituted as to preclude addition to the numbers included within a class. (4) To whatever class a law may [apply], it must apply equally to each member thereof. Those rules have been restated on various occasions without any material change. . . . It would be well to add a fifth rule, to the effect that [5] the characteristics of each class should be so far different from those of other classes as to reasonably suggest at least the propriety, having regard to the public good, of substantially different legislation.

State ex rel. Risch v. Board of Trustees, 121 Wis. 44, 54, 98 N.W. 954, 957 (1904). The words of this five-part inquiry have been repeated innumerable times. ${ }^{67}$ On some occasions, rather than candidly admitting that the standards were inapposite under the circumstances at hand, we have disingenuously "apphed" the rules in such a perfunctory manner as to render them meaningless. ${ }^{68}$ On other occasions, however, we have carefully and seriously considered whether the standards have been met. ${ }^{69}$ When we apply the intermediate standard of review stated here, it is clear that, to the extent these five criteria are relevant, they should be accorded a inajor role in determining whether a challenger

67. E.g., State ex rel. Strykowski v. Wilkie, 81 Wis. $2 \mathrm{~d}$ 491, 509 n.8, 261 N.W.2d 434, 442-43 n. 8 (1978); Dane County v. McManus, 55 Wis. 2d 413, 423, 198 N.W.2d 667, 672-73 (1972); State ex rel. Real Estate Examining Bd. v. Gerhardt, 39 Wis. 2d 701, 710-11, 159 N.W.2d 622, 627-28 (1968); State ex rel. Baer v. City of Milwaukee, 33 Wis. 2d 624, 633, 148 N.W.2d 21, 25-26 (1967); State ex rel. Ford Hopkins Co. v. Mayor of Watertown, 226 Wis. 215, 222, 276 N.W. 311,314 (1937).

68. For example, in State ex rel. Hammermill Paper Co. v. La Plante, 58 Wis. 2d 32, 75, 205 N.W.2d 784, 808-09 (1973), we took but a five-sentence paragraph to conclude that the five standards were satisfied. The five criteria received equally sketchy treatment in State ex rel. Strykowski v. Wilkie, 81 Wis. $2 d$ at 509,261 N.W.2d at 442-43. Because Strykowski was concerned with a tort law equal protection challenge (medical nnalpractice), the rationale that we adopt today would call for a more serious consideration of the five criteria than was made in Strykowski, although, of course, our constitutional ruling might be unchanged.

69. For example, in Harris v. Kelley, 70 Wis. 2d 242, 252-55, 234 N.W.2d 628, 632-34 (1975), while we upheld this state's statutory definition of wrongful death beneficiaries, we engaged in a neaningful inquiry into whether the five standards had been met, and we decided that indeed they had. Interestingly, although we cited the very deferential equal protection test of McGowan v. Maryland, 366 U.S. 420, 425-26 (1961), at one point, 70 Wis. $2 d$ at 254-55, 234 N.W.2d at 633, we also used language that more closely approximates the equal protection standard we have adopted today for use in the torts context:

While the legislature may, in creating particular rights of action, distinguish between classes of persons, this classification inust be based on [a] proper economic, political or social basis. . . . If the classification does not rest upon a difference between the classes which bears a fair, substantial, natural, reasonable and just relation to the objective of the act, it is a violation of the guaranty . . . that all citizens are entitled to equal protection of the law.

Id. at 251,234 N.W.2d at 632 (citations omitted). Other examples of a meaningful application of the five-part equal protection inquiry include Kallas Millwork Corp. v. Square D Co., 66 Wis. 2d 382, 388-93, 225 N.W.2d 454, 458-60 (1975); State ex rel. O'Neil v. Town of Hallie, 19 Wis. 2d 558, $567-68,120$ N.W.2d 641, 646 (1963); Brennan v. City of Milwaukee, 265 Wis. 52, 55-58, 60 N.W.2d 704, 706-07 (1953). 
lias established a violation of equal protection.

\section{Discussion and Evaluation of Plaintiff's Constitutional Contentions and Defendant's Responses Thereto.}

We have little doubt that Wisconsin's system of partial comparative negligence, as established by section 895.045 , Stats., withstands "tlie glancing oversight of the rational basis test,"70 which we have determined to be the applicable standard in this case under the Federal Constitution. In this regard, we are compelled to agree with that portion of Justice Ellis' dissenting opinion infra, in which he concludes that "tliere is some evidence (even though far from compelling) that partial coinparative negligence is justified," and that therefore "[i]t is clear that [such a system] is not unconstitutional" under existing United States Supreme Court precedent. ${ }^{71}$ For the reasons that follow, however, we have concluded that this statutory scheme cannot withstand the inore meaningful equal protection review mandated by the Wisconsin constitution.

1. The 50\% Cut-Off Line. As we noted at the outset of this opinion, section 895.045 , Stats., provides that a contributorily negligent plaintiff can achieve a partial recovery under comparative negligence principles only if his contributory negligence "was not greater than the negligence of the person agamst whom recovery is sought . . ."72 Thus, if a plaintiff is found 50\% negligent, he receives a partial recovery equal to one-half of the dainages he has sustained. If, on the other hand, a plaimtiff is found $51 \%$ negligent, he recovers nothing. In her first niajor argument for invalidating the statute, plaintiff contends that this $50 \%$ cut-off line inipermissibly distimguishes between plaintiffs whose contributory negligence exceeds $50 \%$ and those whose negligence is found to be $50 \%$ or less. ${ }^{73}$

70. Vance v. Bradley, 99 S. Ct. 939, 952 (1979) (Marshall, J., dissenting).

71. Statutes so wholly irrational and arbitrary that they would fail to survive the traditional rational basis scrutiny, as apphed by the United States Supreme Court, must be exceedingly few in number. See Part V.B.1. of this opinion supra, especially note 43 supra and accompanying text. It is unlikely that statutes of the type described, being in sueh basic disharmony with rational hunan decisionmaking, would be enacted in the first instance, let alone retained on the statute books in the face of the sort of public attack that a lawsuit represents. But cf. O'Brien v. Skinner, 414 U.S. 524 (1974) (statutory seheme implicating voting rights characterized as "wholly arbitrary"). In any case, because we ultimately find the statute here in question to be offensive to our state constitution, we see no need for a detailed analysis of the application of federal constitutional standards.

72. Wis. Stat. AnN. $\$ 895.045$ (West Supp. 1978-79).

73. Our research has revealed only two prior cases in which this argument has even been mentioned. In Jackson v. Vangas, 97 Idaho 790, 554 P.2d 968 (1976), the plaintiffs argued that Idaho's comparative negligence statute was unconstitutional 
As plaintiff correctly points out, the primary purpose of comparative negligence is to distribute responsibility for losses more fairly by apportioning that responsibility in accordance with degree of fault, as opposed to requiring parties to bear a degree of responsibility that is disproportionate to their degree of fault. ${ }^{74}$ During recent years,

our court has conducted what might be called a major overhauling of our comparative negligence law and has moved closer to the pure form of the doctrine. We have abolished governmental, charitable, religious, and parent-child immunities. We have abolished the doctrine of the implied assumption of risk .... We have abolished gross negligence and such conduct is now ordmary negligence and the grossness of the conduct is reflected in the comparison of negligence. . . : [W]e have no host-guest statute, no doctrine of imputed negligence to the guest, and no last clear chance doctrine. We consider the elimination or absence of these doctrines essential to the full operation of the comparative neghigence concept.

Hallows, Comparative Negligence, 19 Fed'n Ins. Counsel Q., No. 3, at 71, 76 (1969). Against this backdrop, plaintiff contends that the 50\% cut-off rule "is a misfit in a system designed to distribute responsibility according to degrees of fault," 75 and that this incongruity denies equal protection of the laws to plaintiffs whose contributory negligence is found to exceed $50 \%$.

The numerous critics of partial comparative negligence have de-

as a denial of equal protection of the law on the ground that there is no rational basis for allowing a plaintiff, whose own negligence was $49 \%$ responsible for the plaintiff's injury, partial recovery of her damages while denying a plaintiff whose own negligence was a $50 \%$ or greater cause of her injury all recovery for damages.

Id. at 790, 554 P.2d at 968 . The 1daho Supreme Court refused to address the argument for procedural reasons. Id. at 790-91, 554 P.2d at 968-69. In Bissen v. Fujii, 51 Haw. 636, 466 P.2d 429 (1970), a dissenting justice suggested that Hawaii's partial comparative negligence statute might be unconstitutional on equal protection grounds. Id. at 647,466 P.2d at 436 (Levinson, J., dissenting). See also Brief of Amicus Curiae (John W. Wade, Distinguished Professor of Law, Vanderbilt University) at 35, Epple v. Western Auto Supply Co., 557 S.W.2d 253 (Mo. 1977) ("[Partial comparative negligence] draws an arbitrary fine line that is very dificult to apply and may cause constitutional problems under recent interpretations of the equal-protection clauses."). To our knowledge, we are the first court to face the issue directly. $C$. Wessinger v. Southern Ry., $470 \mathrm{~F}$. Supp. 930 (D.S.C. 1979) (A statute requiring railroad companies to defend against certain claims by proving more than ordinary contributory negligence, e.g., gross contributory negligence, on part of plaintiffs, was found to violate equal protection rights of railroad companies.); Georgia $S$. \& Fla. Ry. v. Seven-Up Bottling Co., 175 So.2d 39 (Fla. 1965) (A coinparative negligence statute applicable only when railroad companies were defendants was found to violate due process and equal protection rights of the railroad companies.); Marley v. Kirby, 245 S.E.2d 604 (S.C. 1978) (A comparative negligence statute, applicable only in automobile aceident cases and not in other tort cases, was found to violate equal protection rights of automobile-accident defendants.).

74. But consider the following confused statement: "[Pure comparative negligence statutes] go too far in abolishing fault as the basis for recovery." REPORT OF THE AMERICAN BAR ASSOCIAtion Special Committee on Automobile Accident Reparations 77 (1971) (einphasis added).

75. Quoting Campbell, supra note 24, at 569. 
nounced the system as one that unjustifiably treats certam plaintiffs much nore harshly than others only slightly less culpable. "Tlie provision in [the Wisconsm] statute which demes recovery to a claimant who is $50 \%$ or inore at fault is out of tune with the general spirit of the comparative negligence rule. When we are free from the shackles of the common law rule treating the claimant's negligence as a coinplete bar it is illogical to call an arbitrary halt at the half way mark. . . . This makes the result depend entirely on chance." Campbell, Ten Years of Comparative Negligence, 1941 Wis. L. Rev. 289, 304. "[Wisconsin's 50\% cut-off rule] is an absurdity. To let a difference of 1 percent of the negligence spell the difference between a . . . recovery and none at all is surely slicing the cheese too thin." Parkhill, $A$ Better Comparative Negligence Rule, 56 A.B.A.J. 263, 263 (1970). "The rule preventimg recovery if plaintiff's negligence exceeds $50 \%$ of the total fault is just as arbitrary as that which coinpletely denies recovery. Is the person who is $49 \%$ negligent that mucl more deserving than the one wlo is $51 \%$ negligent?" Placek v. City of Sterling Heights, 405 Micl. 638, 661, 275 N.W.2d 511, 519 (1979) (citation omitted). "Such a situation, where a mimute alteration in the findings can make such a tremendous difference in the money judgments granted or withheld, is absurd." C. Gregory, Legislative Loss Distribution im Neghigence Actions 64 (1936). "The Wisconsin approach is a giant step in the wrong direction." O. Richardson, Minority Recommendations and Report of the American Bar Association Special Committee on Automobile Accident Reparations 12 (1971). ${ }^{76}$ Meinbers of this court also have contrib-

76. "Either comparative negligence is sound or it is unsound. The compromise in principle which the 50 percent bar rule represents . . . is illogical and unjust." Campbell, Wisconsin Law Governing Automobile Accidents-Part II, 1962 WIS. L. REv. 557, 568. "[This sort of system] distorts the very principle it recognizes, ie., that persons are responsible for their acts to the extent their fault contributes to an imjurious result. The partial rule simply lowers, but does not eliminate, the bar of contributory negligence." Juenger, Brief for Negligence Law Section of the State Bar of Michigan in Support of Comparative Negligence as Amicus Curiae, Parsonson v. Construction Equipinent Company, 18 WAYNE L. REv. 3, 50 (1972). "A very slight difference in the amount of negligence makes a great difference in the judgment. . . . If the principle of comparative negligence is accepted, there is no logical reason why the plaintiff's negligence should be a complete bar to the action where it is equal to or greater than the negligence of the defendant." 7 WIS. L. REv. 122, 123 (1932).

Admittedly, soine of these criticisms are directed to the pre-1971 Wisconsin statute, which was phrased to deprive the plaintiff of any recovery if his negligence was equal to that of the defendant. The legislature amended the statute in 1971 to move the cut-off line shightly, so that the 50\%-negligent plaintiff now achieves a partial recovery, but any negligence beyond 50\% still operates as a complete bar. See note 15 supra and accompanying text. We doubt that these critics would be favorably impressed by the legislature's infinitesimal generosity. Indeed, the basic defect of a cut-off rule remains the same wherever the line is drawn.

For other criticisms of partial comparative negligence, expressing sentiments similar to those we have quoted, see V. ScHWarTz $\$ 21.3$; Campbell, Recent Developments of the Law of Negli- 
uted to the unending flow of critical comment directed against the $50 \%$ cut-off rule. See Vincent v. Pabst Brewing Co., 47 Wis. 2d 120, 177 N.W.2d 513 (1970). 77

The gross unfairness of the rule becomes even more apparent when specific examples of its application are presented. Take the case of a plaintiff with damages of $\$ 10,000$ who is found $51 \%$ negligent. ${ }^{78}$ The plaintiff recovers nothing, even though he would have recovered $\$ 5,000$ had he been found only $1 \%$ less culpable. Professor Campbell suggests an even more striking example involving an accident in which both parties are injured:

Let us assume that $P$ and $D$, drivers of respective cars, each sustain a $\$ 10,000$ loss in a collision, and that $P$ 's negligence is $51 \%$ and $D$ 's negligence is $49 \% ; D$ counterclaims for his damages. Under our present law $P$ bears his entire $\$ 10,000$ loss. He also bears $51 \%$ of $D$ 's loss, or $\$ 5,100$. $P$ 's total loss in the case is $\$ 15,100$. D's loss is $\$ 4,900$. I think everyone will agree that it would be much more just if each

gence in Wisconsin-Part II, 1956 WIS. L. Rev. 4, 21; Campbell, Wisconsin's Comparative Negligence Law, 7 WIS. L. Rev. 222, 246-47 (1932); Keeton, Comment on Maki v. Frelk-Comparative v. Contributory Negligence: Should the Court or Legislature Decide?, 21 VAND. L. REv. 906, 911 (1968); Knoeller, Review of the Wisconsin Comparative Negligence Act-Suggested Amendment, 41 MARQ. L. REv. 397, 415-16 (1958).

In the course of deciding that the admiralty rule of equally divided damages should be replaced by a rule of pure comparative negligence, a unanimous United States Supreme Court spoke in language suggesting that the Court would strongly disfavor a rule of partial comparative negligence:

The Court has long implicitly recognized the patent harshness of an equal division of damages in the face of disparate blame by applying the "major-minor" fault doctrine to find a grossly negligent party solely at fault. But this escape valve, in addition to being inherently unreliable, simply replaces one unfairness with another. That a vessel is primarily negligent does not justify its shouldering all responsibility, nor excuse the slightly negligent vessel from bearing any liability at all.

United States v. Reliable Transfer Co., 421 U.S. 397, 406 (1975) (footnote omitted).

For examples of the smattering of literature that supports partial, as opposed to pure, comparative negligence, see Ghiardi, Comparative Negligence-The Case Against a Mississippi $T_{y p e}$ Statute, 10 For DeF. 61 (1969); Gilmore, Comparative Negligence from a Viewpoint of Casualt . $^{\circ}$ Instirance, 10 ARK. L. REv. 82 (1956); Hayes, Rule of Comparative Negligence and Its Operation in Wisconsin, 23 OHı BAR 233 (1950) (address to Ohio State Bar Association, May 26, 1950); Whelan, Comparative Negligence, 1938 WIS. L. Rev. 465, 49l. See also Bradley v. Appalachian Power Co., 256 S.E.2d 879,885 (W. Va. 1979) (judicially adopting a rule of partial comparative negligence).

77. Chief Justice Hallows has criticized the rule in harsh terms:

There is nothing just in requiring a defendant to pay 51 percent of the plaintiffs damages when the plaintiff is 49 percent at fault and allowing the defendant to go scot-free when he is 49 percent at fault and the plaintiff is 51 percent at fault. What is so magic about being less than, greater than, or equally negligent, that justice must depend on it? Vincent v. Pabst Brewing Co., 47 Wis. 2d 120, 136, 177 N.W.2d 513, 520 (1970) (Hallows, C.J., dissenting).

78. For cases in which unfortunate plaintiffs were found to be $51 \%$ negligent and thereby barred from any recovery, see Van Wie v. Hill, 15 Wis. 2d 98, 112 N.W.2d 168 (1961); Jackson v. Vangas, 97 Idaho 790, 554 P.2d 968 (1976). 
bore substantially the same loss in such a case. ${ }^{79}$

Campbell, 1941 Wis. L. Rev. at $305 .{ }^{80}$

79. Indeed, in such a case, the common law rule of contributory negligence, under which each party would bear his own loss, would result in a fairer distribution of responsibility than obtains under our version of comparative neghigence. See Campbell, 7 WIS. L. Rev., supra note 76, at 246-47; Wade, Uniform Comparative Fault Act, 14 Forum 379, 385 (1979) ("If both parties have been injured, [partial comparative negligence] is worse than the old common law contributory-negligence rule, exacerbating the treatment of the party more at fault. Under [partial comparative negligence], he must bear not only all of his own loss but also the greater part of the loss of the other party. This is true injustice."). See also Wade, A Uniform Comparative Fault ActWhat Should It Provide?, 10 U. MICH. J. LAw. REF. 220, 225 (1977) (In cases in which both parties have been injured, "it is apparent that [pure comparative negligence] always divides the loss according to the established fault percentage, while [partial comparative negligence] fluctuates wildly and very unfairly.").

Some comparative negligence jurisdictions do not permit set-offs in negligence cases. See, e.g., R.I. GEN. LAws \$ 9-20-4.1 (Supp. 1978). This approach allows a recovery by each party agamst the other's liability imsurer, without the dimmution in recovery that a set-off would require. The Uniform Comparative Fault Act deals more directly with the question of recovery in cases in which each party has compensable damages and at least one party has liability imsurance. Prior to a 1979 amendment, section 3 of the Act provided that set-offs would be available, but that when one or both of the parties had liabihty imsurance, any insured party could recover directly from his insurer the amount by which the imsurer's liability for damages to the other party was reduced by reason of a set-off. The 1979 amendment to section 3, although not intended to change the end result in any given case, modified the procedure for reaching this result, basically by calling for payments into and distribution by the court in cases in which uncollectibility is a problem, in lieu of the direct, msurer-to-insured payments that section 3 previously had required. See UNIFORM COMPARATIVE FAULT ACT $\$ 3$. The official comment to section 3 criticizes the strict "no set-off' approach as being unfair when each party recovers a judgment, but only one party has adequate resources or imsurance to pay the judgment agamst him. In such a case, the party having adequate insurance or resources is forced to pay the entire judgment against him, without the benefit of a set-off, while the judgment that he recovered goes unenforced.

80. In the past, especially stark injustices could arise when multiple defendants were present, because the plaintiff's neghigence would be compared with that of each tortfeasor separately to determine if the plamtifi's negligence "was not greater than the negligence of the person against whom recovery is sought." WIS. STAT. ANN. \$895.045 (West Supp. 1978-79). See Walker v. Kroger Grocery \& Baking Co., 214 Wis. 519, 252 N.W. 721 (1934) (first establishing rule of individual comparison). Chief Justice Hallows suggested the unfairness of the rule by the use of an example:

Under the present rule, if the plaintiff is 34 percent negligent and defendant $A$ is 33 percent negligent and defendant $B$ is 33 percent negligent, the plaintiff cannot recover against either $A$ or $B$ although his negligence is not as great as their combimed neghgence; this is unfair.

Gross v. Denow, 61 Wis. 2d 40, 54-55, 212 N.W.2d 2, 10 (1973) (Hallows, C.J., dissenting im part). This rule of individual comparisons, as we apphed it, also created injustices for defendants seeking contribution in multiple-defendant cases:

The Wisconsin rule has also worked a hardship in contribution cases because, although Bielski $v_{*} \cdot$ Schulze ... established pure comparative neghigence in situations where multiple defendants are seeking contribution among themselves, this rule only applies after sec. 895.045 , Stats., is applied. Thus, if the plaintiff is 30 percent negligent and defendant A 20 percent, defendant B 10 percent, defendant C 40 percent, while the three defendants are 70 percent guilty, plaintiff can recover only against defendant $C$ who must pay 70 percent of plaintiff's damages and can recover nothing by way of contribution against defendants $A$ and $B$ because they have no common liability with defendant $\mathrm{C}$ to the plaimtiff. 
The apparent unfairness resulting from the disparate treatment of plaintiffs who are more than $50 \%$ negligent, as compared to plaintiffs who are 50\% neghigent or less, does not, in itself, render our comparative negligence statute invalid. It does, however, require us to examine closely the four justifications that have been presented in support of the $50 \%$ cut-off rule in order to determine whether any of them reflects a legitimate and meaningful legislative goal that is realistically furthered by this statutory distimction.

The first proposed justification for the 50\% cut-off rule is that the rule furthers the desirable goal of preventing preponderant wrongdoers from benefiting froin their own wrongs. The suggestion "is that it is morally improper to allow a party who is more at fault in an accident to recover from one whose blameworthiness is less." V. Schwartz $\S 21.3$, at 344 (footnote omitted); see Ghiardi, Comparative Negligence-The Case Against a Mississippi Type Statute, 10 For Def. 61, 64 (1969) ("It would be compensatimg a flagrant wrongdoer under the guise of a fault system.") (citation omitted). ${ }^{81}$ In a day less far removed from the traditional contributory negligence rule in this state, this proposed rationale for the $50 \%$ cut-off line might be more persuasive. ${ }^{82}$

Vincent v. Pabst Brewing Co., 47 Wis. 2d 120, 137, 177 N.W.2d 513, 520-21 (1970) (Hallows, C.J., dissenting).

Recently, however, in May v. Skelley Oil Co., 83 Wis. 2d 30, 264 N.W.2d 574 (1978), we announced that a

majority of the court has become convinced that comparing the negligence of the individual plaintiff to that of each individual tortfeasor-rather than comparing the negligence of the individual plaintiff to that of the coinbined negligence of the several tortfeasors who have collectively contributed to the plaintiffs injuries-leads to liarsh and unfair results . . . .

Id. at 38, 264 N.W.2d at 578. Although a majority of the court found May an mappropriate vehicle for official promulgation of the new rule of combined comparison, it is clear that our altered approach will be applied in all future cases raising the issue. See Soeldner v. White Metal Rolling \& Stamping Corp., 473 F. Supp. 753, 755 (E.D. Wis. 1979) (applying Wisconsin law) ("Since May is the inost recent expression of the Wisconsin supreme court on the issue at bar, I deem it proper to apply it to this case.").

81. See Hayes, supra note 76, at 236 ("[I]f a person who is injured is more to blame for his own imjury than the person is who injured him ... the mjured person should not recover dainages."); $c f$. Gilmore, supra note 76, at 85 ("I would hope that the Arkansas courts will not permit recoveries under your new law in the ridiculous case when plaintiff's causal negligence clearly exceeds defendant's."); Powell, Contributory Negligence: A Necessary Check on the American Jury, 43 A.B.A.J. 1005, 1061 (1957) (Under pure comparative negligence, "a plaintiff guilty of the grossest negligence is nevertheless entitled to recovery from a defendant guilty only of the slightest negligence.'") (citation omitted).

82. See Cainpbell, Ten Years of Comparative Negligence, 1941 WIs. L. Rev. 289, 294 ("One of the fundamental characteristics of the Wisconsin statute is its retention of enougl of the individualistic spirit of the common law to deny relief to a claimant whose neghigence is equal to or greater than that of a person whoin he is seeking to hold responsible."); Ghiardi, supra note 76, at 64 ("[Allowing a inore-than-50\% negligent plaintiff to recover] would offend the basic sense of justice of the majority of pcople who are indoctrinated with the historic principles of tort litigation.") 
But our partial comparative negligence system is nearly fifty years old "and its limitation is not now in accord with modern concepts of social justice." Vincent v. Pabst Brewing Co., 47 Wis. $2 \mathrm{~d}$ at 135, 177 N.W.2d at 520 (Hallows, C.J., dissenting). "A [partial] comparative negligence [system] is . . unacceptable. Such a policy fails to rehabilitate the viction in a substantial number of imstances. . . . To permit some vague notions of what is 'inorally right' to defeat [this interest in relabilitation] is nonsensical." McDougal, Comprehensive Interest Analysis versus Reformulated Governmental Interest Analysis: An Appraisal in the Context of Choice-of-Law Problems Concerning Contributory and Comparative Negligence, 26 U.C.L.A. L. Rev. 439, 471 (1979) (footnote omitted). 'Even on the extremely abstract level of 'morality,' it is difficult to understand why it is not 'morally wrong' to permit an mjuror to escape responsibility for the portion of the deprivation attributable to his wrong." Id. 473 n.170. We agree, of course, that a plaintiff should bear his own loss to the extent that his own lack of care contributed to the loss. See Placek v. City of Sterling Heights, 405 Micli. at 661, 275 N.W.2d at 519. But the basic comparative negligence concept can and does accommodate this concern, without employing the vicious device of an absolute bar, by diminishing the plaintiff's recovery to the extent of his negligent contribution to the damages suffered. ${ }^{83}$

This proposed justification for the 50\% cut-off line withers further im light of the fact that, when multiple defendants are present, a plaintiff can recover under our present statutory scheme from a defendant whose negligence is less than the plaintiff's own, as long as the plaintiff's negligence is not greater than the combined negligence of all of the defendants. ${ }^{84}$ Thus, if plaintiff $A$ is $30 \%$ negligent, defendant $B$ is $55 \%$

(emphasis added; citation omitted); $c$. Astin v. Chicago, M. \& St. P. Ry., 143 Wis. 477, 484, 128 N.W. 265, 268 (1910) ("[l]n case of an injury proximately caused by want of ordinary care on both sides, however slight such want of care may be on the part of the injured party, in the law, it is damnum absque injuria. In other words, the doctrine of coinparative negligence has no place whatever in our system.").

83. See Vincent v. Pabst Brewing Co., 47 Wis. 2d 120, 135-36, 177 N.W.2d 513, 520 (1970) (Hallows, C.J., dissenting). This reduction in the plaintiff's recovery, based on the extent of his own fault, also tends to negate the contention that a system of pure coinparative negligence is "a step toward a no-fault system." $I d$. at 138,177 N.W.2d at 521 .

In considering the moral desert of a contributorily negligent plaintiff, it must also be borne in mind that the plaintiff's lack of care, being self-directed, is less culpable than the lack of care of a defendant, which is directed toward another. See text accompanying note 112 infra.

84. Admittedly, the rule allowing a plaintiff to recover froun less negligent defendants, as long as the plaintiff's negligence does not exceed the aggregate of the defendants' negligence, is a recent court-made development, announced in May v. Skelley Oil Co., 83 Wis. 2d 30, 264 N.W.2d 574 (1978). See note 80 supra. Thus, one could contend that the incongruity that we describe "has been manufactured by judicial interpretation." Brown v. Merlo, 8 Cal. 3d 855, 880 n.20, 506 P.2d 212, 230 n.20, 106 Cal. Rptr. 388, 406 n.20 (1973); cf. Comunent, Change of the Wisconsin Compar- 
negligent, and defendant $C$ is $15 \%$ negligent, $A$ can recover against $C$ as well as against $B$, even though $A$ 's negligence exceeds that of $C$. Because, in a multiple-defendant situation, a plaintiff can obtain a comparative negligence recovery from a defendant less culpable than himself, it is difficult to imagine how the $50 \%$ cut-off rule can be justified as a rule designed to preclude a more serious wrongdoer from obtaining a judgment against one whose fault is of a lesser degree.

Thus, the statutory disparity im treatinent between plaintiffs falling above the $50 \%$ cut-off line and those falling below the line cannot be justified on the ground that plaintiffs found unore than 50\% neghigent are too culpable to deserve any recovery. But suppose there were some merit in the discredited notion that a plaintiff who has crossed the $50 \%$ culpability line deserves no recovery. If such were the case, plaintiffs rightly would be entitled to exacting determinations of fault, given the extreine consequences that flow from a finding that a plamtiff's negligence was $51 \%$, rather than $50 \%$. But a coinparative negligence system cannot achieve this sort of precise accuracy. Fact-finders in comparative negligence cases inake estimations of the amount of negligence attributable to each party. "We cannot hold juries to the use of calipers to evaluate ratios precisely. We must accept rough generalizations rather than fine distinctions." Horn v. Snow White Laundry \& Dry Cleaning Co., 240 Wis. 312, 319, 3 N.W.2d 380, 383 (1942). Such a system of approximations is, of course, far superior to the systen of contributory neghigence that it has replaced. ${ }^{85}$ Contributory neghigence is a crude, "all or nothing" systein of loss distribution. In stark contrast, comparative negligence strives to distribute the burden of loss in

ative Negligence Statute in Multi-Defendant Suits: May v. Skelly [sic] Oil Co., 62 MARQ. L. REv. 227, 244 (1978) (criticizing the rule announced in May) ("[Earlier cases] clearly document the fact that the individual comparison rule is a product of section 895.045 and the language contained therein. Therefore, the supreme court's inherent power to alter the common law has no application to the individual comparison issue. This rule is of statutory origin."). But we believe that the rule announced in $M a y$ was a sound exercise of judicial interpretation. The rule previously followed, calling for a comparison of the plaintiff's negligence with that of each individual tortfeasor, had been strongly criticized by members of our own court as well as by courts of other jurisdictions. Sce, e.g., Gross v. Denow, 61 Wis. 2d 40, 52-55, 212 N.W.2d 2, 9-11 (1973) (Wilkie, J., concurring, and Hallows, C.J., dissenting in part); Vimcent v. Pabst Brewing Co., 47 Wis. 2d 120, 135-36, 177 N.W.2d 513, 520 (1970) (Hallows, C.J., dissenting); Walton v. Tull, 234 Ark. 882, 89195, 356 S.W.2d 20, 25-26 (1962); Graci v. Danon, 374 N.E.2d 311, 316-18 (Mass. App.), affd, 383 N.E.2d 842 (Mass. 1978). Moreover, we could not then foresee the constitutional attack with which we deal today. In any event, we inust judge the statute for constitutional purposes as it would operate if not found invalid, and we innst, therefore, consider all judicial glosses placed on the statute.

85. See Daly v. General Motors Corp., 20 Cal. 3d 725, 742, 575 P.2d 1162, 1172, 144 Cal. Rptr. 380, 390 (1978); V. ScHWARTz § 21.1, at 335-36; Comment, Assumption of Risk in a Comparative Negligence System-Doctrinal, Practical, and Policy Issues, 39 Oнго ST. L.J. 364, 372 (1978). 
accordance with fault. Fact-finder determinations of comparative fault cannot be expected, however, to attain the degree of accuracy that should be required when, as in Wisconsin, a very slight difference in the apportionment of fault can trigger such a drastic difference in result. ${ }^{86}$

As a second justification for the $50 \%$ cut-off line drawn by our statute, defendant asserts that such a line is necessary to prevent comparative negligence from resulting in soine recovery for every plaintiff, even though the defendant in fact should be found free from liability. "This argument evinces a curious lack of confidence in the jury systein. A jury now finds defendants without fault and will continue to do so ...."Vincent v. Pabst Brewing Co. 47 Wis. 2d at 139, 177 N.W.2d at 522 (Hallows, C.J., dissenting). Dean Prosser has analyzed this arguinent as follows:

It has been said that the restriction is necessary to prevent the jury from giving the plaintiff something in every case, even where the defendant may not be neghigent at all, or is at fault to the extent of only $1 \%$ of the total. But this ignores the fact that the court still has control over an unjustified apportionment, and that a $1 \%$ recovery will be insignificant, and less than the nuisance value of the suit. Actually, the writer has found no such cases.

Prosser, Comparative Negligence, 51 Mich. L. Rev. 465, 494 (1953). ${ }^{87}$ We believe that this proposed justification for the $50 \%$ cut-off line is utterly baseless, and therefore we see no reason to discuss it further.

Third, defendant proposes to justify the cut-off rule on the ground that abandonment of the rule, if accoinpamed by the adoption of pure comparative negligence, would result in increased claims and fewer settlements, thereby adding further to the already lieavy workload of our courts. ${ }^{88}$ A proper analysis of this proposed basis for upholding our coinparative negligence statute requires us to separate defendant's con-

86. Our views and concerns in this regard obviously are not shared by the Supreme Court of Appeals of West Virginia. In its recent decision adopting partial comparative negligence, the court stated:

The argument that the difference between recovery at 49 percent contributory negligence and no recovery at 50 percent or above is an arbitrary line, is probably more theoretical than real. It is doubtful that any jury will be able to shice contributory negligence so

thinly . . . . In all probability, when the contributory negligence rises near the 50 percent level the jury will conclude that plaintiff is guilty of such substantial contributory negligence that it will $f x$ his percentage at 50 or higher to bar his recovery.

Bradley v. Appalachian Power Co., 256 S.E.2d 879, 884 n.12 (W, Va. 1979) (emphasis added).

87. Accord, O. Richardson, MiNORITY RECOMMENDATIONS AND REPORT OF THE AMERICan Bar Association Special Committee on Automobile ACCident Reparations 13 (1971) ("[T]his obsessive fear of Robin Hood juries, who rob non-negligent, habitual defendants to redistribute wealth and productive funds to mjured plaintiffs, ignores the fact that the court still has control over an unjustified, off-the-rails apportionment . . . .").

88. See Ghiardi, supra note 76 , at 64 . 
tention into its component parts.

A system of pure comparative negligence might indeed result in inore claims by injured parties than does the truncated version of comparative neghigence now in force in this jurisdiction. An injured person who concludes that he was more neghigent than his potential defendant would be unlikely, because of the 50\% cut-off line, to assert a claim under our present system. But such a person might well assert a claim under a systein of pure comparative negligence, because, although his substantial contributory negligence would proportionately dimmish his recovery, it would not operate as a complete bar. $C f$. Rosenberg, Comparative Negligence in Arkansas: A "Before and After" Survey, 13 Ark. L. Rev. 89, 108 (1959) (empirical study concluding that coinparative negligence system results in more claims than traditional contributory negligence system). ${ }^{89}$

The inere fact that claims might increase, however, is itself of little constitutional import. The very function of our constitutional review in this case is to determine whether plaintiff's ability to assert a claim has been unconstitutionally impaired. The obvious result of any decision holding a statute unconstitutional is to vary the legal rights of certam persons, thereby inevitably affecting the number of claims asserted by or against these persons.

Defendant contends further, however, that under a system of pure coinparative negligence, there would be not only inore claims, but also fewer settlements, and that this would unduly burden our courts. ${ }^{90} \mathrm{We}$ find no inerit in this contention. A system of pure comparative negligence surely would lead to a greater frequency of settlements than our present systein does, because a pure system would reduce the range of

89. On the other hand, any increase in claims undoubtedly would be much less than if all injured persons were experts in tort law and closely monitored changes in the law of torts. One study has concluded that "comparative negligence has no effect upon the claims consciousness of the general public." Peck, Comparative Negligence and Automobile Liability Insurance, $58 \mathrm{MicH}$. L. REV, 689, 726-27 (1960).

90. In a society of linited resources, the government has a legitimate interest in conserving the use of those resources. Thus, the government has an interest in preventing unduly burdensome workloads for the judiciary that inight either forestall judicial consideration of important cliims or require the allocation of more resources to the judiciary, thereby perhaps decreasing the allocation of resources to other meritorious societal purposes. But a concern that courts may be forced to consider more litigated cases is of only limited inportance in constitutional adjudication.

If the claims are legitimate and they cannot be settled and litigation results, courts should

hear them. What has the number of claims to do with justice? Justice is not secured or maintained by denying a remedy. The anount of crime can be cut down, too, by repealing criminal laws.

Vimcent v. Pabst Brewing Co., 47 Wis. 2d 120, 138, 177 N.W.2d 513, 521 (1970) (Hallows, C.J., dissenting); $c f$. United States v. Reliable Transfer Co., 421 U.S. 397, 408 (1975) ("Congestion in the courts cannot justify a legal rule that produces unjust results in litigation simply to encourage speedy out-of-court accommodations."). 
potential results at trial, thereby bringing negotiating parties closer together in discussing settlement. Suppose, for exainple, the parties to an action are agreed that the plaintiff's damages are $\$ 10,000$ and that the defendant has no damages of his own. ${ }^{91}$ The plaimtiff contends that a jury would likely find the defendant to have been $60 \%$ neghigent, thus entitling the plaintiff to a $\$ 6,000$ recovery. The defendant, on the other hand, believes that he would be found to have been only $40 \%$ negligent, and the plaintiff $60 \%$ neghigent. Under our present system, the defendant's position would be that the plaintiff is entitled to nothing, because his recovery would be cut off by the Wisconsin statute's "not greater than" language. The negotiating parties would be $\$ 6,000$ apart. Under a pure system, the defendant's position would be that the plamtiff is entitled to $\$ 4,000$, instead of the $\$ 6,000$ that the plaintiff is arguing for. The parties would be only $\$ 2,000$ apart, and a settlement would be much more likely. ${ }^{92}$

Moreover, in evaluating an argument relating to the workload and congestion of the courts, we must do more than simply assess the effect upon our trial courts. According to one critic, "[t]he depressing result of the Wisconsin approach . . . is that it incites migraine in the judicial process . . . [and] generates excessive, prolix and costly appeals, in which the court is asked to unscramble, scrutinize, and second-guess a jury's findings of comparative fault . ..." $\mathrm{O}$. Richardson, Minority Report at 14.

Our 50\% cut-off rule has brought about frequent appeals by defendants seeking appellate court deternninations that particular conduct by a plaintiff was, as a matter of law, sufficiently great to put him over

91. The force of this hypothetical would not be reduced if there were a dispute over damages; pure comparative negligence would still reduce the range of potential trial verdicts as compared to the potential verdicts under partial comparative negligence. This hypothetical case, without a dispute concerning damages, was selected merely to keep the example simple.

92. See V. SchWARTz $\$ 21.3$, at 346-47; cf. Whelan, supra note 76 , at 490 ("[The Wisconsin comparative negligence statute, when compared to traditional contributory negligence,] has probably tended to lessen negligence litigation. When there is no absolute bar as a matter of law to recovery for fault, it follows that the person alleged to be at fault and against whom a claim is made is not in a position to deny liability."). See in addition Hayes, supra note 76, at 236 ("[Because many fewer cases are actually tried than under traditional contributory negligence, the Wisconsin comparative negligence statute] has greatly lightened the burden of our courts and lias enabled our State to contimue with nearly the same number of judges on its circuit and municipal benches as we had in 1931 . . .."); Rosenberg, Comparative Negligence in Arkansas: $A$ "Before and After" Survey, 13 ARK. L. REV. 89, 108 (1959) (empirical study concluding that comparative negligence, as opposed to traditional contributory negligence, promotes before-trial settlements). "Experience with comparative neghigence in the personal injury area teaclies that a rule of fairness in court will produce fair out-of-court settlements." United States v. Reliable Transfer Co., 421 U.S. 397, 411 (1975) (footnote omitted) (holding that admiralty rule of equally divided damages is to be replaced with a rule of pure comparative negligence). 
the $50 \%$ cut-off line, thereby barring his recovery. See Prosser, 51 Mich. L. Rev. at 491-93. "It is difficult to be happy about the Wisconsin cases, or to escape the conclusion that at the cost of many appeals they have succeeded inerely in denying apportionment in inany cases where it should have been made." Id. 494. A systein such as our present one leads "inevitably to inany difficult appeals abounding in confusion." Id. 508. See also V. Schwartz $\S \S 17.3$, at 281-82, 18.3, at 304-05, 18.7 , at 315-18.

When a plaintiff, found to be more than $50 \%$ negligent, decides to appeal, our court systein must first hear the appeal and then-if the appeal is successful-face the distinct possibility that the case will have to be dealt with again at the trial level. "The hybrid rule . . promotes appeals on the narrow but all-important question whether plaintiff's negligence was equal to defendant's. In Wisconsin it has led to numerous reversals and the granting of new trials for unjust apportionment." Juenger, Brief for Negligence Law Section of the State Bar of Michigan in Support of Comparative Negligence as Amicus Curiae, Parsonson v. Construction Equipment Company, 18 Wayne L. Rev. 3, 51 (1972) (footnotes omitted); cf. Placek v. City of Sterling Heights, 405 Mich. at 661,275 N.W.2d at 519 (quoting Kirby v. Larson, 400 Mich. 585, 64243, 256 N.W.2d 400, 428 (1977)) ("We acknowledge that even under the 'pure' form of comparative negligence there will be appeals concerning the percentage of award, but it is undoubtedly more compelling to appeal when you have been awarded nothing than when you have received some compensation.").

We are convimced that a system of pure comparative negligence, rather than placing additional burdens on our courts, probably would lessen the burdens that already exist under our present system. We therefore reject this third proposed justification for the 50\% cut-off rule.

A fourtl and final proposed rationale for the statutory rule is that it keeps liability msurance rates in check, thereby benefiting all policyholders. As Chief Justice Hallows noted in Vincent v. Pabst Brewing Co., 47 Wis. $2 d$ at 138, 177 N.W.2d at 521 (Hallows, C.J., disscnting), this assumes that in a large number of cases the plaintiff is more negligent than the defendant and that the increase in insurance company loss would require an increase in rates. See Ghiardi, 10 For Def. at 64; Gilmore, Comparative Negligence from a Viewpoint of Casualty Insurance, 10 Ark. L. Rev. 82 (1956).

The evidence that imsurance rates would be significantly higher, were it not for the 50\% cut-off rule, is dubious at best. While there is some support for the arguinent that a pure systein results in higher rates, it generally takes the form of second-hand "hearsay" within the 
insurance industry. ${ }^{93}$ On the other hand, an in-depth statistical analysis suggests that rates under pure comparative negligence probably would not be any higher, and certainly would not be significantly higher. See Peck, Comparative Negligence and Automobile Liability Insurance, 58 Micl. L. Rev. 689 (1960). ${ }^{94}$ Thus, we doubt whether an interest in avoiding increased imsurance rates is appreciably furthered by the statutory cut-off line.

In any event, we seriously question whether an asserted mterest im the stabilization of insurance premiums, even if furthered by the statutory scheme, is the sort of legislative purpose that constitutes adequate justification for a statutory distinction that denies compensation to a substantial group of claimants who have been harmed by the tortious conduct of others. "The suggestion is that one class of injured persons should be forced to accept their loss without compensation, in order that the public generally may enjoy lower insurance rates. . . . Such a proposition is hardly compatible with principles of equality." Roberts v. Johnson, 588 P.2d 201, 204 (Wasl. 1978). "This is hardly an argument based upon equity and justice." Vincent $v$. Pabst Brewing Co., 47 Wis. $2 \mathrm{~d}$ at 138,177 N.W.2d at 521 (Hallows, C.J., dissenting). ${ }^{95}$

The proposed "insurance rates" justification for our comparative negligence statute is grounded on a very questionable governmental in-

93. See, e.g., Gilmore, supra note 76 , at 83 :

From what we hear from claims executives and others the report on the Mississippi type is $100 \%$ adverse. The view is unanimous that the Mississippi law has increased the number of claims and the amount of settlements and judgments. In a survey we made of comparative negligence law states several years ago, we were advised that many specious cases reach the jury and result in substantial verdicts. We were also told that quite frequently juries in Mississippi disregard the plaintiff's negligence and base their verdict on the amount of plaintiff's damage.

Insurance industry representatives who appeared before the $1970 \mathrm{Wisconsm}$ Legislative Advisory Committee, which was considering whether our state should adopt pure comparative negligence by statute, urged that partial comparative negligence be retained $\mathrm{m}$ order to prevent an increase in imsurance costs. But "these representatives presented no statistical evidence of their contention. In fact, the representative from the Alnerican Family Insurance Company indicated that although he had some imforination regarding costs, it 'probably would not stand close scrutiny because of the difficulty imvolved in predicting costs.' " V. ScHWARTz $\$ 21.3$, at 346 (footnote omitted).

94. Professor Peck's study dealt with the effect of the adoption of coinparative negligence on the insurance rates of jurisdictions that previously had operated under the traditional contributory negligence rule. "Generally speaking, . . . it must be said that no effect from comparative negligence appears in the data." Peck, supra note 89, at 726. "Its effect, if any, would probably go undetected in the rates and statistics of the insurance industry." Id. 728. See also Rosenberg, supra note 92. If the removal of the contributory negligence bar has little or no effect on insurance rates, we find it difficult to beheve that the less drastic change from partial to pure comparative negligence would have any appreciable effect. See V. SCHWARTZ § 21.3, at 345-46.

95. Cf. Note, supra note 56, at 969 ("While the [California medical malpractice] legislation is alleged to represent a balance between the various competing interests involved, the Act's tort reform provisions, in fact, utilize medical nalpractice victims as instruments in an attempt to obtain a stable insurance inarket."). 
terest that is no more than tenuously furthered by the statutory scheme. As such, it cannot serve as a basis for upholding the statute against constitutional attack.

We have addressed each proposed rationale for the 50\% cut-off line and have found that none of them provides adequate justification for this statutory rule of law. Indeed, "[i]t appears impossible to justify the rule on any basis except one of pure political coinpromise." Prosser, 51 Mich. L. Rev. at $494.9^{96}$ Under the relevant criteria of our oftrepeated five-part equal protection inquiry, ${ }^{97}$ our analysis compels us to conclude that the $50 \%$ cut-off line embodied in section 895.045 , Stats., is not "based upon substantial distinctions which make one class really different from another." 98 Nor is it in any meaningful sense "germane to the purpose of the law."99 Moreover, the characteristics of the two classes of plaintiffs created by the statute are not "so far different . . . as to reasonably suggest at least the propriety, having regard to the public good, of substantially different legislation."100 In terms of the intermediate standard of equal protection review that we apply today, the cut-off rule does not realistically advance any meaningful legislative end.

Although we thus have concluded that the $50 \%$ cut-off line, in itself, renders section 895.045 , Stats., unconstitutional, we do not rest today's decision solely on that ground. Plaintiff has offered a second equal protection argument that we have found persuasive as an imdependent and alternative basis for the result we reach today. We turn now to our analysis of that argument.

2. The Presence of "Pure Contribution." Plaintiff's second equal protection contention is bottomed upon her perception that the legislature and this court, for seventeen years, have cooperated in maintaining and applying, with deinonstrably mequitable results, two vastly different systems of coinparative negligence. Plaintiff claims that the existence of this two-track system, when analyzed and viewed in proper

96. The sub-rule barring recovery in the case of equal or greater negligence on the part of plaintiff amounts to a partial retention of contributory negligence. Thus it is well suited to serve as the basis for political compromise. Groups who dislike comparative negligence tend to exact the sub-rule as a quid pro quo for consenting to reform proposals. Thus legislatures tend to prefer partial to pure comparative negligence.

Juenger, supra note 76, at 50 .

97. See text accompanying notes 67-69 supra. The third and fourth requirements of the fivepart test are inapposite to the challenge faced today; it has not been suggested that either of those two standards is violated by our comparative negligence statute.

98. State ex rel. Risch v. Board of Trustees, 121 Wis. 44, 54, 98 N.W. 954,957 (1904).

99. Id.

100. Id. 
perspective, provides an additional ground for finding our comparative negligence statute unconstitutional. This argument requires us to assess the implications of the coinpreliensive loss distribution system created by section 895.045 , Stats., and by our 1962 decision in Bielski $v$. Schulze. ${ }^{101}$

Section 895.045, Stats., relates only to the resolution of negligence conflicts between plaintiffs and defendants. As previously stated, the statute requires such litigants to proceed under a system of comparative negligence that is partial ratlier than pure.

Bielski v. Schulze, ${ }^{102}$ on the other hand, dealt witl the inethod to be utilized in determining the amount of liability for contribution between or among tortfeasors who sustain a common liability to an injured party by reason of concurrent causal negligence. More specifically, Bielski presented the issue whether such liability for contribution should be determined on a pro rata (equal shares) basis in accordance with existing precedent, ${ }^{103}$ or whether it slould be determined instead on the basis of the proportion of causal negligence attributable to each tortfeasor. We lield that contributions of cotortfeasors lienceforth sliould be proportionate to the percentage of causal negligence attributable to each. Such an approach, we concluded, "is inore just in distributing the loss in proportion to the degree of negligence or fault whicl caused it." 104

In thus inoving to "contribution on a comparative-negligence basis," 105 we further held that "[t]he right of one tort-feasor to contribution is not barred because his negligence may be equal to or greater than the negligence of his co-tort-feasor." 106 Thus, for purposes of contribution, we adopted and now adlere to a system of comparative negligence that is pure rather than partial. In the period since Bielski, the legislature not only has acquiesced in that decision but also, in effect, lias codified it. 107

101. 16 Wis. 2d 1, 114 N.W.2d 105 (1962).

102. Id.

103. See, e.g., Mitchell v. Raymond, 181 Wis. 591, 195 N.W. 855 (1923); Ellis v. Chicago \& N.W. Ry., 167 Wis. 392, 167 N.W. 1048 (1918).

104. Bielski v. Schulze, 16 Wis. $2 d$ 1, 10, 114 N.W.2d 105, 109 (1962). Bielski did not abrogate the rule of joint and several hability: "We make it plain . . . this refinement of the rule of contribution does not apply to or change the plaintiff's right to recover against any defendant tortfeasor the total amount of his damage to which he is entitled." Id. at 6, 115 N.W.2d at 107 . For a discussion of the status of joint and several liability following today's decision, see note 132 infra.

105. Id. at 8,114 N.W.2d at 108.

106. Id. at 6,114 N.W.2d at 108 .

107. Section 893.22, Stats., for example, establishes a one-year statute of limitations for "[a]n action for contribution based on tort if the right of contribution does not arise out of a prior judgment allocating the comparative negligence between the parties." WIs. STAT. ANN. $§ 893.22$ 
As the foregoing discussion indicates, plaintiff obviously is correct in asserting that this state, for nearly two decades, has mamtamed a two-track coinparative negligence systein, with a pure, or full, track for tortfeasors seeking contribution and a partial, or foreshortened, track for injured claimants seeking relief in basic negligence actions. Recognition of this fact, lowever, resolves nothing. It merely affords a factual predicate for the dispositive inquiry: can the state, consistent with equal protection guarantees, relegate plaintiffs to the foreshortened track, thereby barring recovery in a case such as this, while at the same time affording a full track for tortfeasors seeking contribution?

It is clear that our two-track system places a contributorily negligent plaintiff in a far less favorable position than a negligent defendant sceking contribution. Plaintiff contends that sucli discrimination is illogical and unjust. She believes that no ineaningful distmction can be drawn between a contributorily negligent plaintiff who seeks partial relicf from the full burden of his damages and a fault-laden defendant who seeks partial relief from the full burden of a common liability for injuries lie and others have caused. In terms of the nature and merits of their respective claims, plaimtiff believes sucl litigants are legally imdistinguishable and thcrefore must be accorded equal treatment before our courts. Accordingly, plaintiff contends that our present two-track system of loss distribution, which does not allow these similarly situated litigants to proceed on an equal footing, cannot be justified by any lcgitimate and meaningful governmental imterest or purpose.

Defendant, in response, asserts that there is a constitutionally significant difference between a plaimtiff wliose negligence exceeds that of the defendant but who nonetheless seeks a court-enforced (albeit reduced) recovery, and a tortfeasor who, no matter low great the degree of his fault, seeks proportional contribution from a co-wrongdoer. Casting the argument in equal protection terins, defendant contends that there is a legitimate and nieaningful governmental interest in refusing to allow a preponderant wrongdoer, such as the plaintiff lere, to utilize our court systein to achieve a net recovery. In defendant's view, the state should not be forced to become a reluctant accomplice in a scheme designed to facilitate the enrichinent of such a serious wrongdoer. Conversely, under defendant's theory, the judiciary is in no way besmirclicd when called upon to accommodate a preponderant wrongdoer in a contribution action. Defendant contends that in such a situation the authority of the court is not being employed to enforce a net

(West Supp. 1978-79) (emphasis added). See also id. $\S \S 893.155,885.285 ; i d . \$ \S 802.01,802.07$ (West 1977). 
recovery. Instead, defendant argues, the court simply makes an equitable reduction in the disproportionate net loss a co-wrongdoer otherwise would be required to sustain.

Two knowledgeable commentators who have, in a nonconstitutional context, assessed the conflicting viewpoints presented here by plaimtiff and defendant differ in their conclusions. Professor Schwartz, on the one hand, has written in support of two-track systems such as ours:

The basic premise used to support the $50 \%$ rule between plaintiff and defendant-that "no one who is more at fault should recover dainages from another"-is simply inapplicable among tortfeasors. In contribution actions, no one is rccovering anything on a net basis; what is being determined is the portion of the cost of plaintiff's award to be borne by each tortfeasor. 108

Professor Campbell, on the other hand, has criticized our two-track system. In a 1941 article he stated:

The close relation between the effect of a plaintiff's negligence on his right to recover damages from the defendant, and the effect of a defendant's negligence on his right to recover contribution from a co-defendant is self evident. . . .

The close relation between the two issues suggests that they should be given similar treatment. . . .

A defendant is entitled to contribution although he is more negligent than his co-defendant. . . . A plaintiff is unable to recover if $50 \%$ or more at fault. This inconsistency should be taken care of by allowing the plaintiff to recover damages irrespective of the amount of his negligence. ${ }^{109}$

Twenty-one years later, in 1962, Professor Campbell again addressed the issue, this time in even stronger terms:

The decision in Bielski v. Schulze which extcnded the rule of coinparative negligence to contribution ... exphasizes the basic conflict between this approach to the distribution of loss, and the common law rule which barred a negligent party. Either compara-

108. V. Schwartz $§ 16.8$, at 270-71 (footnote omitted). Professor Schwartz's view is based on policy alone; he did not address the constitutional implications of differential treatment. Moreover, one might fairly conclude after reading his discussion of two-track systems that his support for them is based primarily upon his fear that "[u]se of the $50 \%$ principle to bar contribution claims between tortfeasors would result in marked unfairness." Id. at 270 . Such an approach "could create almost insurmountable confusion in multi-party actions and would open the door to collusive abuses." Id. at 271. For a jnore detailed discussion of Professor Schwartz's concerns, see note 111 infra.

109. Campbell, supra note 82, at 306. Professor Campbell's views, like those of Professor Schwartz, are based only on pohicy, without regard to constitutional considerations. Professor Campbell's reference to the inability of the plaintiff to recover "if 50\% or more at fault" reflects that his article was written in 1941, thirty years before adoption of an amendinent to the comparative negligence statute that now permits a plaintiff to recover if his neghigence is not greater than that of the defendant. See note 15 supra and accompanying text. 
tive negligence is sound or it is unsound. The compromise in principle which the 50 percent bar rule represents in so far as an injured party seeks relief under our statute is illogical and unjust.

Distribution of loss problems between the defendants and between the plaintiff and the defendant, or defendants, are essentially the same. They should be governed by the same rules. The application of comparative negligence principles to the contribution rule developed by our court . . . is sound. . . .

The plaintiff's right of recovery should be handled the same way. ${ }^{110}$

We agree with Professor Campbell that there is a close and selfevident relation between the effect of a plaimtiff's neghigence on his right to recover damages from a defendant and the effect of a defendant's neghigence on his right to recover contribution from a cotortfeasor. We believe that the claim of a neghigent plaintiff seeking damages and the claim of a neghigent defendant seeking contribution are legally indistinguishable, and that any system of loss distribution that treats them differently is imconsistent, illogical, and unjust. We find defendant's "achievement of a net recovery" versus "reduction of a net loss" distmction unpersuasive and lacking in constitutional significance. Both a negligent plaintiff seeking damages and a negligent defendant seeking contribution are attempting to achieve equitable improvements in their then-existing financial positions. Each, if successful, will realize a gain in his net worth. Each is simply seeking to have another assume his fair share of a loss that, by definition, both have caused. Neither is seeking enrichment that is unjust or unwarranted. Each, in effect, is atteinpting to enlist the aid of the court in the collection of a debt that is due. If the guarantee of equal protection is to have any meaning in this context, it surely requires that litigants in such similar positions be accorded equal treatment. ${ }^{111}$

110. Campbell, supra note 24, at 568-69 (footnotes omitted). Professor Campbell's reference to the "50 percent bar" reflects that the article was written in 1962, nine years prior to adoption of the amendment referred to in note 109 supra.

111. Defendant suggests that we avoid a constitutional determination with respect to our current two-track system simply by abandoning the pure, or full, track for tortfeasors seeking contribution and adopting instead a partial, or foreshortened, track identical to that presently made available to injured claimants seeking relief in basic negligence actions. Under a single track system of the type suggested by defendant, no tortfeasor would be permitted to obtain contribution from anotlier whiose fault was less than his own. We reject this suggestion for three reasons. First, irrespective of plaintiff's constitutional argument based on the discrimination inherent im our two-track system, we have concluded that our comparative neghigence statute is unconstitutional on other grounds. See Part V.C.l. of this opimion supra. Accordingly, the modification proposed by defendant would not save section 895.045 , Stats., froin a declaration of unconstitutionality. Second, as we have noted, see note 107 supra and accompanying text, the legislature lras, in effect, codified the rule of pure contribution, thus precluding judicial lawmaking of the type suggested by defendant. Third, even if it were possible to avoid a constitutional determina- 
As the foregoing discussion indicates, we have concluded that there is no legally significant difference between a contributorily negligent plaintiff who, as a preponderant wrongdoer, seeks a recovery diininished by the percentage of his own causal fault, and a defendant who, as a preponderant wrongdoer, seeks proportional contribution froin a less negligent co-tortfeasor. In light of this conclusion, we are unable to perceive how, as defendant contends, a court systein engages in degrading behavior when it aids such a plaintiff but performs an appropriate judicial function when it aids such a defendant. Indeed, the question of court besmirchment can be turned against defendant, who has raised the issue in support of a two-track system that discriminates against a contributorily negligent plaintiff im favor of a neghigent defendant seeking contribution. Courts long have recognized that the wrongdoing of a plaintiff whose only fault is contributory negligence is fundamentally different, in nature and quality, from that of a negligent defendant. In such a situation, the inner-directed fault of the plaintiff registers more hightly on the scales of culpability than the other-directed wrongdoing of the defendant. As the Supreme Court of Califorina recently observed,

[E]ven when a plaintiff is partially at fault for his own injury, a plaintiff's culpability is not equivalent to that of a defendant. In this setting, a plaintiff's negligence relates only to a failure to use due care for his own protection, while a defendant's negligence relates to a lack of due care for the safety of others. Although we [have] recognized . . . that a plaintiff's self-directed negligence would justify reducing his recovery in proportion to his degree of fault for the accident, the fact remains that insofar as the plaintiff's conduct creates only a risk of self-injury, such conduct, unlike that of a negligent defendant, is not tortious. ${ }^{112}$

tion by accepting defendant's suggestion, we would be unwilling to pay the high price that such a decision would exact. We agree with Professor Schwartz that "use of the $50 \%$ principle to bar contribution claims between tortfeasors would result in marked unfairness," V. SCHWARTZ § 16.8, at 270:

Barring contribution claims by use of the $50 \%$ principle could create almost insurmountable confusion in multi-party actions and would open the door to collusive abuses, especially in intrafamily cases or other cases involving both a passenger and his driver. Suppose, for example, a passenger mjured in a two-vehicle collision (or an insurer by subrogation after payments under a medical coverage) brings an action against both his own driver and the driver of the other vehicle. The driver of the vehicle in which the passenger was riding (perhaps a member of the family) is found $40 \%$ negligent and the driver of the other vehicle $60 \%$. The passenger then proceeds to execution and recovers his full judgment from the driver of the other vehicle. If contribution from the driver who was $40 \%$ negligent is barred, then the plaintiff's own driver goes scot-free, simply because the plaintiff chose to execute against the other driver first.

.. [I]t is easy to see why no state with modified [i.e., partial] comparative neghgence has applied the modification to claiuns for contribution and why the overwhelming majority have applied pure comparative negligence to contributions among tortfeasors.

Id. 271.

112. American Motorcycle Ass'n v. Superior Court, 20 Cal. 3d 578, 589-90, 578 P.2d 899, 906, 
Finally, we observe that a recent decision of this court has seriously undermmed defendant's argument that there is a legitimate and meaningful governmental interest in refusing to allow a plaintiff to invoke the aid of the court to achieve a recovery against a defendant less negligent than the plaimtiff. In May v. Skelley Oil Co., 83 Wis. 2d 30, 264 N.W.2d 574 (1978), the court decided, in the interest of fairness, to abandon the long-standing rule that, in an action against multiple tortfeasors, the negligence of the plaintiff must be compared to that of each individual tortfeasor. ${ }^{113}$ Under the approach announced in May, a contributorily negligent plaimtiff is entitled to invoke the aid of a court in obtaining a joint and several recovery against inultiple tortfeasors as long as the combined negligence of the tortfeasors either equals or exceeds the percentage of neghigence attributable to the plaintiff. Even if the plaintiff's negligence exceeds that of any one of the defendants, or indeed that of each of the defendants, he may still recover against the full tortfeasor group and each member thereof. ${ }^{114} \mathrm{We}$

146 Cal. Rptr. 182, 189 (1978) (footnote omitted); accord, Seattle First Nat'l Bank v. Shorelime Concrete Co., 588 P.2d 1308 (Wash. 1978):

[A plaintif's] culpability is not of the same nature as defendant's. A plamtiff's negligence relates to a failure to use due care for his own protection whereas a defendant's negligence relates to a failure to use due care for the safety of others. While a plaintiff's self-directed negligence may justify reducing his recovery in proportion to his degree of fault, the fact remains that such conduct, unlike that of a negligent defendant, is not tortious.

Jd. at 1314 (emphasis in original). Cf. W. PROSSER, supra note 3:

It is perhaps unfortunate that contributory negligence is called negligence at all. "Contributory fault" would be a more descriptive term. Negligence . . . is conduct which creates an undue risk of harm to others. Contributory negligence is conduct which involves an undue risk of harm to the actor himself. Negligence requires a duty, an obligation of conduct to another person. Contributory negligence imvolves no duty . . . .

$I d$. $\S 65$, at 418 . In this case, for example, plaintiff's sole fault was her failure to use due care for her own protection; she did not create unreasonable risks with respect to the safety of others. There are situations, of course, in which a plaintiff not only fails to use due care for his own safety but also fails to use due care for the safety of others. In sucl circumstances, the nature and quahity of the plaintiff's wrongdoing does not differ from that of the defendant.

113. See, e.g., Walker v. Kroger Grocery \& Baking Co., 214 Wis. 519, 252 N.W. 721 (1934) (first establishing the rule of individual comparison).

114. It may become necessary for us to recognize limited exceptions to the general rule of joint and several liability just stated. See, e.g., Soeldner v. White Metal Rolling \& Stanping Corp., 473 F. Supp. 753 (E.D. Wis, 1979) (applying Wisconsin law). Soeldner, while performing duties for his employer, fell from a ladder manufactured by the White Metal Rolling and Stamping Corporation. Soeldner filed for workman's compensation benefits from his employer pursuant to Wisconsin law. In addition, he brought a tort action against the manufacturer of the ladder. Soeldner's einployer was not named as a defendant in the suit, masmuch as Soeldner's sole remedy against his employer was under workman's compensation. In his tort action agamst the manufacturer, the plaintiff was found to have been $32 \%$ negligent, his employer $60 \%$ negligent, and the defendant ladder manufacturer $8 \%$ neghigent. (Although the plaintiff's employer was not a party to the court action, under Wisconsin law the jury was required to determine the degree, if any, of the employer's causal neghigence.) The court held that the plaintiff employee was entitled to recover from the manufacturer because the employee's negligence was less than the combined negh- 
believe that May has destroyed much of whatever validity previously might have attached to defendant's argument that the state has an imterest in denying relief to any plaintiff whose neghigence exceeds that of one or more of the defendants in a basic neghigence action. ${ }^{115}$

We conclude that our two-track comparative negligence system, when viewed as a comprehensive loss distribution scheme, is, as plaintiff claims, both illogical and mainfestly unjust. We are convinced that no legitimate and ineaningful governmental interest is realistically advanced by the highly discriminatory configuration of this system. As we have stated countless times in the past:

All classification must be based upou substantial distimctions which make one class really different from another. . . . [T] he characteristics of each class should be so far differeut from those of other classes as to reasonably suggest at least the propriety, having regard to the public good, of substantially different legislation. ${ }^{116}$

Our analysis compels the conclusion that our two-track system, when measured against these standards, must be found constitutionally want-

gence of the employer and the defendant manufacturer. The court, however, limited the plaintiff's recovery against the ladder manufacturer to $8 \%$ of the damages suffered and refused to hold the defendant manufacturer jointly and severally hable for both its own and the employer's negligence combined (i.e., for $68 \%$ of the plamtiff's damages). The court gave several reasons "why the application of joint and several habihty to cases hike the instant one would be particularly unfair," id. at 755 :

[1] [I]n most negligence cases; while a defendant may often be held responsible for inore than its proportional share of damages, it then has a claim agamst the other negligent defendants for those damages which exceed its proportional share under the doctrine of contribution. . . . In the instant action . . . , such will not be the case. . . . In any case to which Wisconsin's workman's compensation law applies, a negligent third party who is held liable for compensation to an injured employee, is precluded from requiring contribution from such employee's employer, even though the employer inght be negligent to a far greater degree than the third party. . . .

[2] [P]lacing disproportionate hability on the defendant in this case is unjustified since the [plaintiff] may well have been compensated already for much of the damage for which the [defendant] would be liable. . . . While the legislature explicitly provided for separate actions against third parties in workman's compensation cases . . . , the purpose of such suits can be fully realized if third parties are liable to the extent they are causally negligent. Liability beyond this proportion is particularly unfair where a plaintiff is more responsible for the injury than is the defendant, and the plaintiff already has received compensation for that mjury. . . .

[3] [T] he application of joint and several liability to a case such as this could lead to the inisallocation of legal and judicial resources. Jomt and several liability would encourage the filing of marginal cases against third party defendants whose negligence is questionable or minimal, smce such defendants would be liable not only for their own negligence but for that of the employer as well. Holding such defendants liable only to the extent they themselves are neghigent will allow such defendants to be held accountable to the extent they have caused injuries, without encouraging litigation brought primarily to recover for injuries caused by neghigent employers.

Id. at 755-56. A conclusion similar to that reached by the court in Soeldner was recominended in Cominent, supra note 84 , at 258-59.

115. For a discussion of the injustices arising under our prior rule of individual comparison, and a further discussion of May, see note 80 supra. For an explanation of why our use of May in support of today's decision does not partake of judicial "bootstrapping," see note 84 supra.

116. State ex rel. Risch v. Board of Trustees, 121 Wis. 44, 54, 98 N.W. 954, 957 (1904). 


\section{ing. ${ }^{117}$ Thus, there remains for our consideration only defendant's final}

117. Should our declaration of unconstitutionality be followed in those jurisdictions that currently maintain two-track systems similar to our own, the effect upon the law of comparative negligence in the United States would be profound. According to Professor Sehwartz, 23 states, including Wisconsin, have enacted partial comparative negligence statutes under which a contributorily negligent plaintiff can achieve a proportionately diminished recovery if (but only if) his causal negligence is less than, or, under an alternative formulation, is no greater than, that of the defendant. V. ScHWarTZ $§ 16.8$, at 268-71; id. at 102-03 (Supp. 1978). In addition, one state, West Virginia, has adopted partial comparative negligence by judicial decision. See note 129 infra. Of course, we have found that the existence of partial comparative negligence in itself violates equal protcction norms. See Part V.C.1. of this opinion supra. In addition, however, all of these 24 partial comparative negligence jurisdictions maintain two-track systems that are subject to the same contention of unconstitutional discrimination as that successfully presented by the plaintiff in this case:

(l) Nine of these jurisdictions-Maime, Minnesota, Montana, New Jersey, North Dakota, Pennsylvania, Texas, Wyoming, and our own state of Wisconsin-provide a pure comparative negligence track for tortfeasors seeking contribution.

(2) Nine of these jurisdictions-Arkansas, Colorado, Georgia, Hawaii, Idaho, Massachusetts, Oregon, Utah, and West Virginia-calculate contribution on a pro rata, or equal sliares, basis. With this type of contribution track, as with a pure contribution track, a tortfeasor whose percentage of fault exceeds that of one or more co-tortfeasors is not barred from obtaining contribution from them. Moreover, in five of these states-Arkansas, Colorado, Hawaii, Idaho, and Utah-an alternative pure comparative negligence track for contribution is provided in instances in which there is such a disproportion of fault among the tortfeasors as to render inequitable a pro rata distribution of the common hability.

(3) One partial comparative negligence jurisdiction-Connecticut-prohibits contribution. The Connecticut loss distribution schemc, by providing plaintiffs a partial track and defendants none at all, permits a discrimination against defendants even more pernicious than the discrimination against plaintiffs that we have today found to be impermissible.

(4) The remaining five partial comparative negligence jurisdictions--Kansas, Nevada, New Hampslire, Oklalıma, and Vermont-liave abolished joint and several liabihity, and therefore eaeh defendant is liable to the plaintiff for only that portion of the judgment that represents the percentage of negligence attributable to him. Under this arrangement, no tortfeasor is required to pay more than his fair share of the judgment, and hence no formal contribution procedures are required. It appears, lowever, that these states do, in effect, maimtain pure systems of contribution, and that these de facto systems result in discrimmation in favor of defendants (and against plaintiffs) that is even more pronounced than in states such as Wisconsin. In jurisdictions having partial comparative negligence without joint and several liability, the ultimate liability of tortfeasors is the same as im states such as Wisconsin, except that tortfeasors are not required to seek a formal contribution determmation and, in addition, do not bear the risk that a co-tortfeasor may be insolvent and hence unable to satisfy a contribution judgment. Thus, more culpable defendants are in the same position as if they had received contribution from less culpable defendants, whereas more culpable plaintiffs are denied recoveries against less culpable defendants.

The preceding summary of the law of contribution in partial comparative negligence jurisdictions (but not the analysis thereof) is derived from V. SCHWARTz $\$ \S 16.7,16.8$ (1974 \& Supp. 1978), the appendix to the opmion of the California Court of Appeal in American Motorcycle Ass'n v. Superior Court, 65 Cal. App. 3d 694, 708, 135 Cal. Rptr. 497, 506 (1977), rev'd en banc, 20 Cal. 3d 578, 578 P.2d 899, 146 Cal. Rptr. 182 (1978), and the following cases and statute that postdate the Schwartz and American Motorcycle compilations: Brown v. Keill, 224 Kan. 195, 580 P.2d 867 (1978) (joint and several liability not apphicable in action under state's comparative negligence statute); Bartels v. City of Williston, 276 N.W.2d 113 (N.D. 1979) (later-enacted comparative negligence act, which authorizes contribution on a pure comparative negligence basis, held impliedly to repeal portion of earlier-enacted legislation providing for contribution on a pro rata basis); 


\section{argument.}

3. Defendant's "One Step at a Time" Argument. In its brief and at oral argument, defendant has vigorously argued that, despite any infirmities in our system of partial comparative negligence, the adoption of this system "was a great step forward and alleviated some of the hardship of contributory negligence,"118 and that a "statute is not invalid on equal protection grounds because it might have gone further than it did."119 It is true that courts often defer to legislative judgments

Laubach v. Morgau, 588 P.2d 1071 (Okla. 1978) (under state's comparative negligence system, eacl defendant severally liable only for that portion of award attributable to him); Bradley $v$. Appalachian Power Co., 256 S.E.2d 879 (W. Va. 1979) (judicially adopting partial comparative negligence); CoLo. REv. STAT. \$§ 13-50.5-101, -106 (Supp. 1978) (pro rata contribution authorized except when disproportion of fault among tortfeasors would render such approacli mequitable, in which case contribution based on proportional fault is available).

Our decision, if followed, also would require a major alteration of the law in states such as 1llinois, Washington, and Michigan. lllinois adlieres to the doctrine of contributory negligence. Maki v. Frelk, 40 Ill. 2d 193, 239 N.E.2d 445 (1968). Among tortfeasors, however, Illinois permits contribution on a pure comparative negligence basis. Skinner v. Reed-Preutice Div. Package Mach. Co., 70 Ill. 2d 1, 374 N.E.2d 437 (1977), cert. denied, 436 U.S. 946 (1978). Illinois' discrimination agamst plaimtiffs, and in favor of defendants seeking contribution, is thus even more stark than the discrimination we have ruled to be unconstitutional in this case. The Supreme Court of the United States, lowever, recently refused to consider a federal equal protection challenge to lllinois' loss distribution system. Verdonck v. Freeding, 56 Ill. App. 3d 575, 371 N.E.2d 1109 (1977), cert. denied, 439 U.S. 837 (1978). In Washington, an equally offensive system discriminates in the opposite direction: a pure comparative negligence approach obtains as between plaintiffs and defendants, WASH. REV. CODE $\$ 4.22 .010$ (Supp. 1978), but contribution among tortfeasors is prohibited. Wenatchee Wenoka Growers Ass'n v. Krack Corp., 89 Wasl. 2d 847, 576 P.2d 388 (1978). Michigan, by judicial decision, recently embraced the doctrine of pure coinparative negligence. Placek v. City of Sterling Heights, 405 Mich. 638, 275 N.W.2d 511 (1979). Contribution, however, is awarded on a pro rata basis. Mich. CoMp. LAws $\S \S 600.2925 \mathrm{a}, .2925 \mathrm{~b}$ (1970). As a inember of the Supreme Court of Michigan has stated, "[o]f particular concern is the present statute providing for contribution between joint tortfeasors on a pro rata basis. . . . The legislation is mconsistent with a pure comparative neghigence system." Placek v. City of Sterling Heights, 405 Mich. 638, 700 n.12, 275 N.W.2d 51 1, 537 n.12 (1979) (Coleman, C.J., concurring in part and dissenting in part). Of course, if lllinois would move to a pure comparative negligence system and if Washington and Michigan would authorize contribution on a proportionate fault basis, the discriminatory aspects of their current approaches would be eliminated.

118. Quoting Vimcent v. Pabst Brewing Co., 47 Wis. 2d 120, 134, 177 N.W.2d 513, 519 (1970) (Hallows, C.J., dissenting).

119. Quoting State ex rel. Strykowski v. Wilkie, 81 Wis. 2d 491, 512, 261 N.W.2d 434, 444 (1978); accord, City of New Orleans v. Dukes, 427 U.S. 297, 303, 305 (1976); Katzenbach v. Morgan, 384 U.S. 641, 657 (1966); Williamson v. Lee Optical Co., 348 U.S. 483, 488-89 (1955); Madison Metropolitan Sewerage Dist. v. Comunittee on Water Pollution, 260 Wis. 229, 255-56, 50 N.W.2d 424, 438 (1951).

Defendant suggests that partial comparative negligence is not as liarsh as it miglit seem, because collateral benefits such as medical insurance and social security compensation, which often are available to injured persons, can be obtamed even thouglt the imjured person is barred by his own negligence from recovering in a tort action. Because this tends to mitigate the harshness of our comparative negligence cut-off line, just as it once mitigated the harshness of traditional contributory negligence, defendant contends that the legislature's part-way approach does not rise to 
on the ground that the legislature should be free to deal with problems one step at a time. See, e.g., Williamson v. Lee Optical Co., 348 U.S. at 489. This deference is predicated on "the perceived need for experimentation, especially in social and economic matters." Manistee Bank \& Trust Co. v. McGowan, 394 Mich. at 672, 232 N.W.2d at 642.

We agree that Wisconsin's adoption of partial comparative negligence was a welcome innovation. ${ }^{120}$ But this advanceinent occurred nearly fifty years ago, and therefore we no longer find ourselves on the frontier of coinparative neghigence. ${ }^{121}$ The time for experimentation has passed. ${ }^{122}$ At least when our intermediate standard of equal protection review is applicable, we cannot use the "one step at a time" doctrine as a vehicle for disregarding the long-standing and continuing

the level of a constitutional deficiency. But collateral benefits are available to plaintiffs who can recover in tort as well as those who cannot, i.e., to those who are 50\% negligent or less as well as those who are more than $50 \%$ negligent. We fail to perceive how the potential presence of collateral benefits in any way justifies a distinction between plaintiffs based upon which side of the $50 \%$ cut-off line they fall. In any event,

[i]t is illogical and unjust to argue [that] collateral benefits are a form of compensation to a plaintiff denied recovery and therefore no great injustice is done. [The possible availability of $\mathrm{m}$ ]edical and hospitalization insurance and social security should not relieve a tortfeasor from liability for his negligence. Suppose a plaintiff has no medical or hospital insurance or is too young for social security? The collateral-source-rule argument should not be allowed to overshadow the justice of pure comparative negligence.

Vincent v. Pabst Brewing Co., 47 Wis. 2d 120, 138-39, 177 N.W.2d 513, 521-22 (1970) (Hallows, C.J., dissenting). For a student piece suggesting that the collateral source rule is itself outmoded and unjustified, see Comment, The Collateral Source Rule: Double Recovery and Indifference to Societal Interests in the Law of Tort Damages, 2 U. PugET Sound L. Rev. 197 (1978).

120. "It should be remembered that under the common law even more fatal results were dependent on a single degree of fault. If plaintiff was $1 \%$ at fault he recovered nothing. If entirely free from fault, he recovered 100\%." Hayes, supra note 76, at 235.

121. See Hallows, Comparative Negligence, 19 FED'N INS. Counsel Q., No. 3, at 71, 77 (I969) ("While there was a practical legislative justification in the beginning for keeping contributory negligence as a bar in some situations, the current needs of society require a comparison of the full range of negligence.").

Defendant argues that the 1971 legislative amendment to our comparative negligence statute, which extended the reach of comparative negligence apportionment principles to the 50\%-negligent plaintiff, indicates that the legislature is still experimenting with comparative negligence and should be allowed further time to refine the doctrine. If the 1971 amendment is any indication of the legislature's propensity to correct the imjustices of partial comparative negligence, we would be in for a long wait were we to give the legislature more time to deal with the problem. At this rate of incremental "experimentation," man would never have invented the wheel, let alone the electric light or computer technology.

122. It is understandable that a court reviewing what may be "experimental" legislation would say,... . "[p]erhaps the legislature also had other reasons for the law." Where, however, it can no longer be claimed that the legislation is experimental, where all possible rationales have been developed, a court should not dismiss a constitutional challenge on that hypothesis.

Manistee Bank \& Trust Co. v. McGowan, 394 Mich. 655, 672, 232 N.W.2d 636, 643 (1965); $f$. Georgia S. \& Fla. Ry. v. Seven-Up Bottling Co., 175 So. 2d 39, 40 (Fla. 1965) ("[A] statute which is valid when enacted may become invalid by changes in the conditions to which it applies. This is unquestionably the law."); accord, Wessinger v. Southern Ry., 470 F. Supp. 930 (D.S.C. 1979). 
existence of unjustifiable statutory discrimination. ${ }^{123}$

"[T]he basic reason for the existence of the doctrine of comparative negligence is social justice and a modified form which demes such justice in some cases produces only modified justice." Hallows, 19 Fed'n Ins. Counsel Q. at 77. We conclude that this modified form of justice is forbidden by the constitutional guarantee of equal protection of the laws. We hold that section 895.045 , Stats., is unconstitutional and hence that it can no longer be allowed to control, and thereby to limit, a claimant's right to recover damages in a negligence action.

\section{Conclusion AND Disposition of APPEAL}

\section{A. Alternatives Available in the Selection of a New System of Loss Distribution.}

For the reasons stated in Part V of this opimion, we have stricken section 895.045 , Stats., as violative of the guarantee of equal protection of the laws embodied in article 1 , section 1 , of the Wisconsin constitution. This ruling requires us to turn next to the task of selecting a new system of loss distribution to replace the system we have held invalid. We have considered three alternatives.

1. Reinstatement of the Doctrine of Contributory Negligence. One option is reinstatement of the traditional doctrine of contributory negligence, which we adopted in 1858 and to which we adhered for nearly three-quarters of a century. ${ }^{124}$ We summarily reject this alternative. In the words of the United States Supreme Court, contributory negligence is a harsh and "discredited doctrine which automatically destroys all claims of mjured persons who have contributed to their injuries in any degree, lowever slight." Pope \& Talbot, Inc. v. Hawn, 346 U.S. 406, 409 (1953). It "is the cruelest and most indefensible doctrine of the common law," Green, The Individual's Protection under Negligence Law: Risk Sharing, 47 Nw. U.L. Rev. 751, 757 (1953), and "can neitlier be justified by theory, nor policy, nor common sense," Juenger, 18 Wayne L. Rev. at 22. As the Supreme Court of Califorma stated at the time of its abandonment of contributory negligence:

[T] he doctrine [of contributory negligence] is inequitable in its operation because it fails to distribute responsibility in proportion to

123. This does not mean that experimentation and "one step at a time" legislation should never be given judicial deference. To the contrary, when the legislature enacts new and different principles of law, part-way enactments should be given considerable deference during the developmental stages of the new legal principles.

124. See notes 13-14 supra and accompanying text. 
fault. . . . The basic objection to the doctrine-grounded in the primal concept that in a system in which liability is based on fault, the extent of fault should govern the extent of hability-remains irresistible to reason and all intelligent notions of fairness.

Li v. Yellow Cab Co., 13 Cal. 3d 804, 810-11, 532 P.2d 1226, 1230-31, 119 Cal. Rptr. 858, 862-63 (1975) (footnote omitted). In rejecting the traditional contributory negligence rule as a viable replaceinent for section 895.045, Stats., we follow the wise counsel of a long-time member of this court: "[T]he unjust doctrine of contributory neghigence . . . does not fulfill the needs of society and ought no longer be harbored and nurtured by the common-law courts . . . ." Vincent v. Pabst Brewing Co., 47 Wis. $2 \mathrm{~d}$ at 133, 177 N.W.2d at 519 (Hallows, C.J., dissenting).

Our rejection of the doctrine of contributory neghigence is also based upon our recognition that reinstatement of the doctrine immediately would confront us with a new constitutional issue. As discussed im Part V.C.2. of this opinion, it is a denial of equal protection to maintain a two-track coinparative neghigence systein, with a pure track for tortfeasors seeking contribution and a partial track for injured claimants seeking relief in basic negligence actions. Were we to reinstate the doctrine of contributory negligence and, at the same time, leave unaltered our current approach to contribution, we would be providing a full track for tortfeasors seeking contribution and no track at all for contributorily neghigent plaintiffs. This would result in discrimination even more egregious than that which led to today's declaration of unconstitutionality. We could, of course, avoid this clear violation of equal protection by not only reinstating contributory negligence but also mandatimg a return to the common law rule prohibiting contribution. But would such a resurrection of doctrines now so largely discredited by modern notions of fairness and justice lead us into a direct confrontation with the requirements of due process? Because we have no intention of taking such a backward leap, we need not address this complex and imtriguing question. ${ }^{125}$

2. Adoption of a "Uniform Discount System." An alternative is to adopt the "uniform discount system" advocated by Justice Doe in her concurring and dissenting opinion. Under this system, fault would

125. Similarly, the Supreme Court of California, by judicially adopting pure comparative negligence, avoided the necessity of ruling on a constitutional challenge to the doctrine of contributory negligence. Li v. Yellow Cab Co., 13 Cal. 3d 304, 830, 532 P.2d 1226, 1244, 119 Cal. Rptr. 858,876 (1975). The constitutionahity of the doctrine of contributory neghigence also was challenged in Angelini v. Snow, 58 Ill. App. 3d 116, 374 N.E.2d 215 (1978). The court refused to consider the challenge for procedural reasons. 
not be coinpared and apportioned; instead, once the trier of fact had determined that a plaintiff's own neghigence had contributed in any degree to his loss, the plaintiff's recovery automatically would be reduced by a fixed percentage ( $40 \%$, for example) that would be uniformly apphed in all neghigence cases in which the plaintiff was found contributorily neghigent. Justice Doe's principal reason for supporting this system of loss distribution is that it avoids coinparison of fault, a task which, in her view, is beyond the ken of humans. She also beheves that the uniform discount system, by promoting consistency and predictability, would encourage out-of-court settlements, thereby avoiding additional court congestion and further increases in insurance costs.

Although beguiling in its simplicity and ease of application, Justice Doe's proposal cannot withstand close analysis, and therefore we reject it. In reaching this conclusion, we have found highly persuasive the unanimous opinion of the Supreine Court of the Umited States in United States v. Reliable Transfer Co., 421 U.S. 397 (1975). In Reliable Transfer the Court was called upon to reassess an admiralty rule, adopted in 1855, that required the equal division of property damage (occasioned, for exainple, by a collision between two vessels) whenever both parties, regardless of their relative degrees of wrongdoing, were found to be guilty of contributory fault. The Court concluded that the divided damages rule should be abandoned, and that it "should be replaced by a rule requiring, when possible, the allocation of liability for damages in proportion to the relative fault of each party." Id. at 398. Justice Doe's proposal, in our view, is an undisguised adaptation of the divided damages rule abandoned by the Supreme Court in Reliable Transfer, and we believe that the Supreine Court's cogent reasoning applies with equal force to Justice Doe's uniform discount proposal.

In Reliable Transfer the Court acknowledged that the lower federal courts, in recent years, had followed the divided damages rule "only grudgingly" and had termed the rule "unfair," "illogical," "arbitrary," "archaic and unjust." Id. at 404. The Court then justified its adoption of pure comparative neghigence in these terms:

It is no longer apparent, if it ever was, that this Solomonic division of damages serves to achieve even rough justice. . . . The rule produces palpably unfair results im [most cases]. For exanıple, where one ship's fault in causing a collision is relatively slight and her damages small, and where the second ship is grossly negligent and suffers extensive damage, the first ship nust still make a substantial payment to the second. "This result hardly commends itself to the sense of justice any nore appealingly than does the common law doctrine of contributory negligence...."

Id. at 405 (footnote and citation omitted). On the question whether 
triers of fact would have the ability to apportion fault, the Court had this to say:

The divided damages rule has been said to be justified by the difficulty of determining comparative degrees of negligence when both parties are concededly guilty of contributing fault. ... When it is impossible fairly to allocate degrees of fault, the division of damages equally between wrongdoing parties is an equitable solution. But the rule is unnecessarily crude and inequitable im a case like this one where an allocation of disparate proportional fault has been made. Potential probleins of proof im some cases liardly require adherence to an archaic and unfair rule in all cases. Every other major maritime nation has evidently been able to apply a rule of comparative negligence without serious problems . ..., and in our own admiralty law a rule of comparative negligence has long been applied with no untoward difficulties in personal injury actions.

Id. at 407 (citations omitted). The Court also rejected a contention that the divided damages rule should be retained because it pronotes outof-court settleinents:

The arguinent has also been made that the divided damages rule promotcs out-of-court settleinents, because when it becomes apparent that both vessels are at fault, both parties can readily agree to divide the damages - thus avoiding the expense and delay of prolonged litigation and the concomitant burden on the courts. . . . Experience with coinparative negligence in the personal injury area teaches that a rule of fairness im court will produce fair out-of-court settlements. But even if . . . [the argument that the divided damages rule promotes out-of-court settlements] were more persuasive than it is, it could hardly be accepted. For, at bottom, it asks us to continue the operation of an archaic rule because its facile application out of court yields quick, though inequitable, settlements, and relieves the courts of some hitigation. Congestion in the courts cannot justify a legal rule that produces unjust results in litigation simply to encourage speedy out-of-court accommodations.

Id. at 407-08 (footnote omitted). ${ }^{126}$

3. Adoption of Pure Comparative Negligence. The third option available to us is adoption of pure comparative neghigence. Under this doctrine, the contributory neghigence of the plaintiff, unless it is found to be the sole proximate cause of the harm suffered, is removed as a bar to recovery. The plaintiff's damages, however, are reduced in proportion to the amount of neghigence attributable to him.

126. Is it a violation of due process to allow the outcome of hitigation to be determined by the application of a rule that is "crude," "unjust," "inequitable," "illogical," "archaic," "arbitrary," and "palpably unfair"? Although our question is merely rhetorical, we do note that all of these terms were used by the Supreme Court in Reliable Transfer to describe the divided damages rule. Inasmuch as Justice Doe's uniform discount system is nothing more than the divided damages rule parading under a different label, it warrants equally strong denunciation. 
Our system of compensation for negligently inflicted injuries is based upon the fundamental premise that fault begets liability. A logical corollary of that premise is that the extent of fault sliould govern the extent of liability. Pure coinparative negligence, unlike otlier comparative fault doctrines, admits of no compromise in lonoring the concept that responsibility is to be distributed im proportion to fault. It is, therefore, the systein of loss distribution that we adopt today to replace section 895.045, Stats. Pure comparative negligence, m our view, "remams irresistible to reason and all intelligent notions of fairness." 127 Indeed, nearly a decade ago, a majority of the members of this court expressed a preference for a full comparison of negligence that would distribute responsibility according to degree of fault without the miposition of an arbitrary percentage bar. See Vincent v. Pabst Brewing Co., 47 Wis. $2 \mathrm{~d}$ at 130-31, 177 N.W.2d at 517-18 (concurring and dissentimg opmions).

Nor is our entluusiasm for pure comparative negligence dampened by the lack of enthusiasm that legislative bodies have shown for the doctrine. As Dean Prosser has stated, this legislative preference for partial, as opposed to pure, comparative negligence "obviously [is] the result of coinpromise in the legislatures, and smack[s] of political expediency rather than any reason or logic in the situation." 128 Dean Prosser's conclusion gams support from the fact that, in four of the five states that have inoved from contributory to comparative negligence by judicial decision rather than by legislative action, the courts, without liesitation, have selected pure comparative negligence as the inost appropriate successor to contributory negligence. See Kaatz v. State, 540 P.2d 1037, 1049 (Alaska 1975) ("We are convinced that the pure system is the one which is the simplest to administer and which is best calculated to bring about substantial justice in negligence cases."); Li v. Yellow Cab Co., 13 Cal. 3d at 828, 532 P.2d at 1243, 119 Cal. Rptr. at 875 ("The dissenting opinion of Chief Justice Hallows [in Vincent $v$. Pabst Brewing Co., 47 Wis. $2 \mathrm{~d}$ at 131,177 N.W.2d at 518] . . stands as a persuasive testimomal im favor of the 'pure' system. We wholeheartedly einbrace its reasoning."); Hoffman v. Jones, 280 So. 2d 431, 438 (Fla. 1973) ("[W]e consider the 'pure forin' of comparative negligence . . . to be the most equitable method of allocatimg damages in negligence actions."); Placek v. City of Sterling Heights, 405 Micl. at 661, 275 N.W.2d at 519 ("[T]he doctrine of 'pure' comparative negligence most nearly accomplishes the goal of a fair system of apportionunent of

127. Li v. Yellow Cab Co., 13 Cal. 3d 804, 811, 532 P.2d 1226, 1231, 119 Cal. Rptr. 858, 863 (1975).

128. W. Prosser, supra note $3, \S 67$, at 437. 
damages.");129 cf. United States v. Reliable Transfer Co., 421 U.S. at 411 ("[W]orldwide experience has taught that . . . [the goal of just and equitable allocation of damages in maritime collision cases] can be more nearly realized by a standard that allocates liability for damages according to comparative fault . . . .").

Pure comparative negligence also has gained wide acceptance among the commentators. Professor Schwartz, the nation's leading authority on comparative negligence, favors the pure form because

129. Of the five states that have moved from contributory to comparative negligence by judicial decision rather than by legislative action, only West Virginia has found partial comparative negligence more appealing than pure. See Bradley v. Appalachian Power Co., 256 S.E.2d 879, 885 (W. Va. 1979). The West Virginia Supreme Court of Appeals adopted partial, rather than pure, comparative negligence for the following reasons:

[1] [Partial comparative negligence] is an intermediate position between the absolute bar of the present contributory negligence rule and the almost total permissiveness of the pure comparative negligence rule. It represents a considerable improvement over the present rule without undertaking a radical change in our present fault-based tort system, as would be the case with pure comparative negligence.

Id. at 887.

[2] We do not accept the major premise of pure comparative negligence that a party should recover his damages regardless of his fault, so long as his fault is not 100 percent. ... [W]e are not willing to abandon the concept that where a party substantially contributes to his own damages, he should not be permitted to recover for any part of them.

Id. at 885 .

It is difficult . . to rationalize a system which permits a party who is 95 percent at fault to have his day in court as a plaintiff because he is 5 percent fault-free.

Id. at 883 .

[3] The difficulty with the pure comparative negligence rule . . is that it focuses solely on the hypothetical "plaintiff" without recognizing that once pure comparative negligence is embraced, all parties whose negligence or fault combined to contribute to the accident are automatically potential plaintiffs unless a particular party is found to be 100 percent at fault.

The practical result of such a system is that it favors the party who has incurred the most damages regardless of his amount of fault or negligence. To illustrate, a plaintiff who has sustained a moderate injury with a potential jury verdict of $\$ 20,000$, and who is 90 percent fault-free, may be reluctant to file suit against a defendant who is 90 percent at fault, but who has received severe injuries and whose case carries a potential of $\$ 800,000$ in damages from a jury verdict. In this situation, even though the defendant's verdict is reduccd by his 90 percent fault to $\$ 80,000$, it is still far in excess of the plaintiff's potential recovery of $\$ 18,000$.

Id. at 883 (footnote omitted).

To create . . . a system where plamtiff's decision to sue may depend not on the degree to which he is free from fault but on his financial ability to withstand the countersuit, is to emphasize unduly the damage aspect and to obscure the relative fault of the parties.

Id. at 885 n. 15 .

For the reasons stated in Parts VI.A.3, and V.C.1. of this opinion, we disagree with the West Virginia court's first two points. Indeed, the court's first point reflects a serious misunderstanding of pure comparative negligence, in that the court suggests that the pure system somehow disserves the policy of fault-based liability. See also note 74 supra. The West Virginia court's third point strikes us as nothing more than an illustrated restatement of the second, i.e., that "a party [who] substantially contributes to his own damages . . . should not be permitted to recover for any part of them." Id. at 885 . 
"[o]nly pure comparative negligence truly distributes responsibility according to fault of the respective partics." V. Schwartz $\$ 21.3$, at 347. For other statements in support of pure comparative negligence, see Juenger, 18 Wayne L. Rev. at 49-51; Keeton, Comment on Maki v. Frelk-Comparative v. Contributory Negligence: Should the Court or Legislature Decide?, 21 Vand. L. Rev. 906, 911 (1968); Prosser, 51 Mich. L. Rev. at 493-94, 508; G. Scliwartz, Contributory and Comparative Negligence: A Reappraisal, 87 Yale L.J. 697, 726-27 (1978).

It also is of great significance that the Uniform Comparative Fault Act, adopted by the National Conference on Uniform State Laws in 1977 by a vote of forty states to eight, embraces pure comparative negligence. ${ }^{130}$ Professor Schwartz has stated that this Act, which was approved by the Conference after five years of discussion and analysis, "is the most thoroughly researched comparative neghigence law that has been presented as a public document in the United States." V. Schwartz § 21.4, at 129 (Supp. 1978).

Our moveinent to pure comparative neghigence should occasion no great difficulty for the bencli and bar of the state. Comparative negligence, albeit in an incomplete form, has been a way of life in this state for nearly fifty years. Moreover, since 1962 pure comparative neghgence has been applied in determining the amount of liability for contribution annong co-tortfeasors. ${ }^{131}$ The existence of these doctrimes has required us to resolve most, if not all, of the important questions that arise under the primciple of comparative fault. Those of our earlier decisions that relate to issues that could arise only as long as section 895.045 , Stats., was controlling are, of course, rendered irrelevant by today's invalidation of the statute. But nany of our previous decisions addressed fundamental issues that are common to botll pure and partial comparative negligence. Under our new system, these decisions will continue to be controlling. Should our move to pure comparative negligence give rise to new questions or suggest the need for new answers to old questions, we will deal with such issues as they arise. ${ }^{132}$

130. "In an action based on fault seeking to recover damages ..., any contributory fault chargeable to the claimant diminishes proportionately the amount awarded as compensatory damages for an injury attributable to the claimant's contributory fault, but does not bar recovery." UNIFORM COMPARATIVE FAULT ACT $\$ 1$. For the full text of the Act and its accompanying comments, see V. SCHWARTZ $\$ 21.4$, at 130 (Supp. 1978). For brief accounts of the history of the development of the Act from the perspective of its principal draftsman, see Wade, Uniform Comparative Fault Act, 14 ForUm 379, 381 (1979), and Wade, A Uniform Comparative Fault ActWhat Should It Provide?, 10 U. Mich. J. LAw REF. 220, 220-23 (1977).

131. See text accompanying notes 102-07 supra.

132. There is, in a sense, one new question that we wish to answer at this time. This question is whether today's decision invalidates the partial coinparative negligence aspects of the following five Wisconsin statutes, each of which requires the application of partial comparative negligence 


\section{B. The Issue of Retroactive Application.}

There remains for resolution a final issue raised by our decision in this case. We must determine to what extent, if any, today's ruling should be given retroactive apphication. Our purpose in holding section 895.045 , Stats., unconstitutional is to accord equal protection of the laws to claimants whose recoveries would otherwise be barred by the statute. In order to fulfill this purpose and to correct past injustices to the extent that sound judicial administration will permit, we believe our decision must be given broad effect. Accordingly, our ruling is to be applied:

(1) In any case filed in the future.

(2) In any case brought to trial after the date of this opinion.

(3) In any case in which the trial has commenced, but the issues have not been subinitted to the trier of fact for decision.

(4) In any concluded case in which there was an unsuccessful challenge to the constitutionality of section 895.045 , Stats., at trial, and the plaintiff, within generally apphicable time limits, either files a inotion to vacate the judgment or, if such a mo-

principles in the circumstances specified: (1) WIS. STAT. ANN. $§ 655.065$ (2)(C) (West Supp. 1979) (negligence of patient bars or diminishes claimant's recovery in medical malpractice proceeding before compensation panel); (2) WIS. STAT. ANN. $\$ 895.04$ (West Supp. 1978-79) (negligence of either decedent or beneficiary bars or diminishes beneficiary's recovery in wrongful death action); (3) WIS. STAT. ANN. \& 895.045 (West 1966) (negligent operation of motor vehicle or motorboat by spouse or minor child of owner bars or diminishes owner's recovery in property damage action against third party owner or operator of other motor vehicle or motorboat involved in accident); (4) WIS. STAT. ANN. § 102.29(2) (West Supp. 1978-79) (negligence of employee bars or diminishes recovery of employer or compensation carrier in action against negligent third party to recover sums paid under workman's compensation); (5) WIS. Stat. ANN. \& 192.50(2), (3) (West 1957) (negligence of einployee of railroad company bars or diminisles employee's recovery in action against company based on negligence of fellow servant).

Although the question whether today's decision should control the resolution of issues under these statutes has been neither briefed nor argued, we see no reason to equivocate. These statutes deal with fundamental, traditional, and important areas of negligence practice. None of the actions controlled by these statutes appears to involve concepts or issues that differ significantly from those presented in the straightforward personal injury action immediately before us. Accordingly, we conclude that the statutes are unconstitutional to the cxtent that they employ partial comparative negligence concepts, and that the doctrine of pure, rather than partial, coinparative negligence shall be utilized in the comparison of fault in the situations addressed by these statutes.

Lest there be any doubt, we also state unequivocally that our adoption of pure comparative negligence in no way affects the general vitality of the doctrine of joint and several liability in this state. Absent special circumstances, see, for example, note 114 supra, a co-tortfeasor whose negligence is a proximate cause of an indivisible injury is individually liable for the total amount of damages attributable to that injury, subject, of course, to a reduction in such danages proportionate to the amount of negligence attributable to the person recovering. For a persuasive recitation of the reasons why the adoption of pure comparative negligence does not warrant abolition or contraction of joint and several liablity, see American Motorcycle Ass'n v. Superior Court, 20 Cal. 3d 578, 586-90, 578 P.2d 899, 903-07, 146 Cal. Rptr. 182, 186-90 (1978). Also see note 104 supra. 
tion has been made and denied, seeks to have his case heard on appeal. ${ }^{133}$

(5) In any concluded case in which there is now pending in the trial court a motion to vacate the judgment, if this inotion renews and seeks reconsideration of an unsuccessful challenge to the constitutionality of section 895.045 , Stats., made at trial.

(6) In any case pending on appeal in which the constitutionality of section 895.045, Stats., was challenged in the trial court, and that challenge has been preserved as a ground for appeal.

(7) In any case that is to be retried because of a reversal of the judgment in the case following an appeal or because of the granting of a new trial by the trial court, which retrial is rcquired because of error(s) unrelated to the constitutionality of section 895.045, Stats.

(8) In this case. ${ }^{134}$

The judgnient appealed from is reversed and remanded to the trial court with directions to enter judgment for plamtiff in the amount of her damages diminished by 55\%, the percentage of causal neghigence attributed to her by the jury.

BAKER, J. (concurring in part and concurring in result). I wholeheartedly agree with Justice Adams' dissection of the various proposed justifications for the arbitrary and unjust system of partial comparative neghigence that heretofore has existed in this jurisdiction. What troubles me is the court's creation of a completely unnecessary "imtermediate standard of review" under our state constitution. Justice Adams' opinion makes it obvious that our comparative neghgence statute does not rationally relate to any legitimate governmental purpose, and that the statute, therefore, is unconstitutional under the applicable federal standard of equal protection review. The niere fact that the federal

133. Conversely, under the fourth category, our decision is not to be apphied in the following situations: first, in any case in which a judgment based on section 895.045 , Stats., has becn entered, and the plaintiff, because the applicable time period has expired, is now precluded from filing a motion to vacate the judgincnt or from seeking to have his case heard on appeal; second, in any case in which a judgment based on section 895.045 , Stats., has been entered and the plaintiff did not challenge the constitutionality of the statute at trial, even though the plaintiff's time for moving to vacate the judgment or for an appeal has not expired.

134. When the Supreme Court of Michigan rccently adopted pure comparative negligencc, the issue of retroactive application of the new rule sharply divided the court. A inajority of the court favored broad retroactivity. Placek v. City of Sterling Heights, 405 Mich. 638, 662-68, 275 N.W.2d $511,520-22$ (1979). Three Justices who dissented on this point argued that the new doctrine should have no retroactive application at all, and that it should be applied only to causes of action arising after the date of the court's decision. Id. at 684-93, 699-701, 275 N.W.2d at 530-34, 537-38. 
rational basis standard is a lenient one does not mean that totally arbitrary and irrational classifications such as this one will withstand scrutiny under that test. ${ }^{135}$ Because $I$ would find the statute unconstitutional under the rational basis standard of review, which we have always applied in cases like this one, ${ }^{136} \mathrm{I}$ cannot agree with Justice Adams' uncalled-for assertion of judicial activism in the name of our state constitution. ${ }^{137}$

CARR, J. (concurring). I concur in Justice Adams' opinion for the court. I agree that section 895.045 , Stats., is unconstitutional and that it should be replaced by a system of pure comparative negligence. I regret, however, that I have been forced, unnecessarily, to reach this conclusion. Although I believe plamtiff and others sinilarly situated should be accorded the benefits of pure comparative negligence, it is not necessary to declare section 895.045 , Stats., unconstitutional in order to achieve this result. In Vincent v. Pabst Brewing Co., 47 Wis. 2d 120, 177 N.W.2d 513 (1970), a majority of the members of this court concluded that the legislature, in partially removing the bar of contributory negligence, did not intend to preempt the common law authority of the court to remove the bar coinpletely. Id. at 130-31, 140, 177 N.W.2d at 517-18, 522. Two years later, following a modest legislative

135. See, e.g., In re Paris Air Crash, 427 F. Supp. 701 (C.D. Cal. 1977) (holding that California's denial of punitive damages in wrongful death actions, while permitting the award of such damages in other personal injury actions and in property damage actions, violates the federal equal protection guarantee). The court in Paris Air Crash correctly observed that the rational basis standard of review does not give a limitless license in econounic and social areas. $\int d$. at 707 n.12. In Sidle v. Majors, 536 F.2d I156 (7th Cir.), cert. denied, 429 U.S. 945 (1976), the Seventh Circuit Court of Appeals suggested that the United States Supreme Court, were it to give the matter plenary consideration, would find Indiana's guest statute to be unconstitutional under the Federal Constitution's rational basis standard of equal protection review. 536 F.2d at 1158-60.

136. In his majority opinion, Justice Adauns adinits that our past cases have dealt with equal protection challenges like this one in terms of a single standard of rational basis review, applicable under both the federal and the state constitutions. See text accompanying notes 47-49 supra. He further admits that we have stricken a number of statutes under this rational basis scrutiny. See note 50 supra and accoinpanying text. But he then concludes that these rational basis decisions finding statutes unconstitutional actually were based exclusively on our state constitution, because he believes that the cases would be erroneous if based on the Federal Constitution's rational basis test. See text accompanying notes $51-53$ supra. In fact, these past cases were correctly decided under the rational basis standard of review, and the case at bar could and should have been decided on the same ground.

137. Cf. Duke Power Co. v. Carolina Environmental Study Group, Inc., 438 U.S. 59, 103 (1978) (Stevens, J., concurring in the judginent) ("We are not statesmen; we are judges. When it is necessary to resolve a constitutional issue in the adjudication of an actual case or controversy, it is our duty to do so. But whenever we are persuaded by reasons of expediency to engage im the business of giving legal advice, we chip away a part of the foundation of our independence and our strength."). 
liberalization of section 895.045 , Stats., 138 this view was repeated in Lupie v. Hartzheim. ${ }^{139}$ At the time of Vincent and Lupie, only one nnember of the court, Chief Justice Hallows, was willing to exercise the court's cominon law authority. The predominant view favored judicial abstention pending further legislative consideration of the subject. In the eight years since Lupie, no legislative change has occurred. I believe, therefore, that the time is ripe for us to "show leadership and in the exercise of [our] inherent power reject in toto the cominon law doctrine of contributory negligence and adopt the doctrine of pure or full coinparison of neghigence." Lupie v. Hartzheim, 54 Wis. 2d at 418, 195 N.W.2d at 462 (Hallows, C.J., dissenting). Were we thus to utilize our cominon law power, we would be reacting to the inconsistencies and harshness of our present tort system in an adequate and yet restrained inaimer. Our authority to declare statutes unconstitutional is an awesoine power. We should shrink from its use whenever, as is the case today, less drastic and equally effective corrective. ineasures are easily within our reach.

DOE, J. (concurring and dissenting). Today, the court has struck down section 895.045 , Stats., on the ground that it violates the equal protection guarantee of our state constitution. To replace the invalidated statute, the majority has judicially adopted the so-called "pure" forin of comparative negligence. While I agree that our present comparative negligence syste1n is constitutionally defective, I beheve the alternative chosen by the majority is both unwise and impractical. Instead of pure coinparative neghigence, I would adopt a uniform discount system, under which a plaintiff's recovery automatically would be decreased by a fixed percentage ( $40 \%$, for exainple) upon a finding of any degree of contributory negligence. In urging this approach, I rely heavily on the persuasive reasoning of Justice Clark of the Supreme Court of Califorina. See Safeway Stores, Inc. v. Nest-Kart, 21 Cal. 3d 322, 334, 579 P.2d 441, 447, 146 Cal. Rptr. 550, 556 (1978) (Clark, J., concurring); Daly v. General Motors Corp., 20 Cal. 3d 725, 748, 575 P.2d 1162, 1175, 144 Cal. Rptr. 380, 393 (1978) (Clark, J., concurring); American Motorcycle Association v. Superior Court, 20 Cal. 3d 578, 608, 578 P.2d 899, 918, 146 Cal. Rptr. 182, 201 (1978) (Clark, J., dissenting).

138. See note 15 supra and accompanying text.

139. 54 Wis. $2 \mathrm{~d} 415,418,195$ N.W.2d 461, 462 (1972) ("[A] majority of the court reasserts the authority . . . [to move to pure comparative negligence] and adheres to its position that passage of the comparative negligence act lias not divested this court of its inherent common-law prerogative of reconsidering matters that stem from judicial decision . . . ."). 
Although pure comparative negligence is both logical and equitable in theory, it is all too often both irrational and unjust im apphication. The system is fatally flawed because humans simply lack the ability to compare fault. Consider, for example, a hypothetical case posed by Justice Clark in Daly v. General Motors Corp., 20 Cal. 3d at 748, 575 P.2d at 1176, 144 Cal. Rptr. at 394 (Clark, J., concurring). Three drivers collide at an intersection. One is intoxicated, another is speeding, and the third drives through a stop signal. In such a case neither logic nor common sense can provide the fact-finder with a standard for comparing fault based on intoxication with that based on speeding or disobeying a traffic signal. Simply put, the fact-finder in such a case is asked to compare apples and oranges. As a result, any comparison of fault at best will be speculative and at worst may only reflect the sympathies or prejudices of the jury.

Even if the negligence displayed by the parties is of the same type, a comparative negligence system, calling as it does for determinations of fault on a percentage basis, remams arbitrary. Consider, for example, the case of an automobile accident involvimg two drivers, both of whom are speeding. Certainly logic dictates that the one traveling at the greater speed should bear the greater responsibility. But how can the fact-finder translate speed into a percentage of causal fault? Neither logic nor common experience will provide a standard for determinimg whether the faster driver is $55 \%$ at fault or $95 \%$ at fault. An arbitrary "best guess" carries the day.

The deficiencies of comparative negligence, as illustrated by these examples, become even more pronounced in multiparty actions. As the number of parties increases, the complexity of the fault comparisons increases exponentially. It is instructive to consider the experience of England and Canada, each of which has moved to a system of compar- ative negligence. As a result of the horrendous difficulties in reaching comparative fault deterninations in multiple-party tort litigation, these countries have virtually elimmated jury trials in such cases. See Prosser, 51 Mich. L. Rev. at 504.

I also object to comparative negligence on the ground that it discourages out-of-court settlements. Because comparative negligence demands arbitrary and speculative findings, it cannot be applied consistently by juries. As a result, the potential liability of a tortfeasor is largely unpredictable, inaking settlements inherently difficult to achieve. This, of course, can only. increase the caseloads of our overburdened trial courts and impede the efficient administration of justice. The increased number of trials under comparative neghgence also mcreases the litigation costs of hability insurers. As a result, a 
greater percentage of every liability insurance premiun is expended to hitigate claims, thus making less efficient the transfer of dollars from those who pay premiums to those who are mjured in accidents. Justice Clark underscores this effect of the comparative neghigence system in his concurring opimion in Safeway Stores, Inc. v. Nest-Kart, $21 \mathrm{Cal} .3 \mathrm{~d}$ at 335,579 P.2d at 448,146 Cal. Rptr. at 557:

Liability insurance dollars should be directed so far as possible to the inaximal benefit of accident victims. A systein of tort liability that greatly increases distribution costs, while allowing arbitrary results, is unfair both to the premmum payer and to the accident victim. The inflated premium cost will mean that some people who would ordinarily insure will not, resulting in some accident victims receiving little or no compensation for their injury.

I ain convinced that the majority's adoption of pure coinparative neghigence is unwise and impractical. I likewise am convinced that we should adopt a uniform discount system of the type described at the outset of this opimion. Under such a system, the fact-finder no longer would be asked to perform the impossible task of comparing fault. Instead, a consistent and predictable allocation of responsibility would obtain in every case and typically would result in a reasonably fair distribution of the loss in question. ${ }^{140}$ Moreover, a uniform discount system, because it yields consistent and predictable results, would encourage out-of-court settlements. ${ }^{141}$

140. Occasionally, of course, if the fault of one party were great and the fault of the other party shight, the approach 1 advocate might reach a result that appears to be arbitrary and unjust. But that would be a small price to pay in order to avoid the uniformly arbitrary, speculative, irrational, and unjust results that obtain under a comparative negligence system.

141. In United States v. Reliable Transfer Co., 421 U.S. 397 (1975), the Supreme Court of the United States abandoned the long-standing admiralty rule of divided damages and adopted in its place the doctrine of pure comparative neghigence. In Part VI of its opinion supra, the majority states that my proposed uniform discount system is an "undisguised adaptation" of the divided damages rule struck down in Reliable Transfer and that the Supreme Court's "cogent reasoning" in that case applies with equal force to my proposal in this case.

With reference to the case before us, I have stated that the inajority's adoption of pure comparative negligence is unwise and impractical. I now wish to state that I also believe that the Supreme Court's adoption of pure comparative neghigence in Reliable Transfer was unwise and impractical for the same reasons. See Epstein, Plaintiff's Conduct in Products Liability Actions: Comparative Negligence, Automatic Division and Multiple Parties, 45 J. A1R. L. \& CoM. 87, 110 (1979) ("[T]he best approach is still that of the older adiniralty cases, however great their disrepute today.") (footnote omitted). To err is human, and the members of the United States Supreme Court, hike the members of this court, are perfectly capable of reacling erroneous conclusions. Compare Part V.B.1. of the majority opmion supra ("We have some sympathy with plaintiff's contention that the extreme judicial deference evidenced by the traditional rational basis test [utilized by the United States Supreme Court] represents an abdication of the judiciary's responsibility im a governmental system of checks and balances. But we do not sit as the highest court in the land, and we are bound by the dictates of the United States Supreme Court concerning matters of federal constitutional law.").

I also wish to remind the majority that this case and Reliable Transfer are different in one 
The majority today appropriately has nullified the unjust system of partial comparative negligence. Unfortunately, this action is coupled with the adoption of a system that is hittle better than the one it replaces. I cannot concur in this aspect of the court's decision. ${ }^{142}$

ELLIs, J. (dissentimg). If I were a legislator rather than a judge, I surely would have voted with my colleagues to replace our rule of partial comparative negligence with a rule of pure comparative neghigence, for the partial rule has indeed proven unwise and unjust. Unlike my

respect. Reliable Transfer was an admiralty case. An admiralty case in federal court is tried to the court, rather than to a jury. See G. GILMORE \& C. BLACK, The LAw of Admiralty § 1-12, at 31 (1957). Although I believe humans generally are incapable of making rational and just fault comparisons, perhaps experienced trial judges are somewhat better equipped than lay jurors to play the guessing game that the doctrine of comparative negligence requires. To whatever extent this distinction between judges and jurors may have vahdity, the majority conveniently has chosen to ignore it.

142. The approach I have advocated in this opinion recently received strong scholarly support. See Epstein, supra note 141, at 107-11 (recommending a system of "automatic apportionment"):

Once it is established that the wrongful conduct. . . of the plaintiff and defendant have jointly brought about the harm in question, the issue is how to apportion loss between them.

The consensus of opinion today is that the "pure form" of comparative negligence best adjusts the competing equities between plaintiffs and defendants. The great advantage of this position is that it removes the possibility that any small shifts in the relative responsibility between plaintiff and defendant will have vast consequences upon the distribution of losses between thein. ...

In spite of this desirable characteristic, there are still strong objections to the pure comparative negligence systein ....

. . The basic mquiry is, how does one generate any set of percentages about plaintiff's and defendant's responsibility from the raw data about their conduct . . . . [T] here is nothing about the particular pattern of factual information, even if perfectly known, that demands any unique set of percentages in any given case. All allocation of responsibility between the two parties is arbitrary, whether by a judge or by jury, whether by lunch or by computer. The claims of individual fairness are ill-served by the pretense that legal principles have a degree of precision that they do not in fact possess. . . . The necessary case by case determinations are both expensive and pointless. They may flatter the legal inind, but they do not advance the orderly adininistration of justice. If individual determinations inust fail, then it is surely best to have a collective decision about the distribution of loss that extends to all cases of joint responsibihty. The only way that such a collective decision can be made is by a fixed judicial or legislative rule that is less concerned witl the false pursuit of perfect equity in the individual case and more concerned with the reduction of adininistrative costs and the introduction of a measure of certainty and predictability into the system.

... Once it is settled that certain harms are jointly caused by two parties, then the loss should be apportioned between them under some fixed formula, probably one that reduces recovery for the jointly caused harms by, for example, 50 percent. The number is by no means perfect, but notling about the facts of any particular case allows further principled refinements. ...

.. Flexible percentages . . do not help one whit. The old contributory [neghgence] rule was unjust, if at all, only because of its "all or nothing" character. The pure comparative negligence rule avoids the all or nothing approach, but only at the cost of a ruinous excursion into the never-never land of fiexible percentages. The fixed apportionment rule escapes the vice of the old contributory negligence rule, while avoiding the routine, but fruitless, pursuit for illusory percentages. The rejection of the absolute bar of contributory negligence leads not to pure comparative negligence, but to automatic division.

Id. (emphasis in original). 
brethren, however, I realize the limitations of my judicial role, and I am not about to substitute my own notions of sound public policy for those of our duly elected legislators.

The constitutional issue in this case is whether our partial comparative negligence statute violates the constitutional guarantee of equal protection. As the majority indicates, the statute does work some injustices. But "[s]tate legislatures are presumed to have acted within their constitutional power despite the fact that, in practice, their laws result in some imequality." McGowan v. Maryland, 366 U.S. at 425-26. "Unconsitutionahty of the act must be demonstrated beyond a reasonable doubt. Every presumption must be indulged to sustain the law if at all possible . . ." State ex rel. Hammermill Paper Co. v. La Plante, 58 Wis. 2d 32, 46, 205 N.W.2d 784, 792 (1973). "The court cannot reweigh the facts as found by the legislature." State ex rel. Strykowski $v$. Wilkie, 81 Wis. $2 d$ at 506,261 N.W.2d at 441 . "In short, the judiciary may not sit as a superlegislature to judge the wisdom or desirability of legislative pohicy determinations made in areas that neither affect fundamental rights nor proceed along suspect lines . . . City of New Orleans v. Dukes, 427 U.S. 297, 303 (1976).

Under the past decisions of this court, and under the decisions of the United States Supreme Court, the classification challenged here must be upheld "unless no ground can be conceived to justify"143 it as being "rationally related to a legitimate state imterest." City of New Orleans v. Dukes, 427 U.S. at 303; see State ex rel. Strykowski v. Wilkie, 81 Wis. $2 \mathrm{~d}$ at $506,261 \mathrm{~N} . W .2 \mathrm{~d}$ at $441-42$. In this case there is some evidence (even though far from compelling) that partial comparative negligence is justified because it protects our courts from undue congestion and protects the general public from higher insurance rates. Moreover, there is certainly some legitimacy in a moral judgment that plaimtiffs who are preponderant wrongdoers should not be permitted recovery in our courts. Our "pure" approach in contribution cases is not inconsistent with this moral judgment. The contribution rule does not allow a preponderant wrongdoer to receive a net recovery in our courts; it only allows him to achieve a partial diminution of his loss. In any event, legislatures "may implement their program step by step .... adopting regulations that only partially amehorate a perceived evil and deferring complete elimination of the evil to future regulations." City of New Orleans v. Dukes, 427 U.S. at 303. It is clear that partial comparative neghigence is not unconstitutional under existing

143. McDonald v. Board of Election Comm'rs, 394 U.S. 802, 809 (1969). 


\section{precedent. ${ }^{144}$}

Not being content to adhere to long-held rules of law, the majority has fashioned a novel approach to equal protection adjudication by adopting an "intermediate standard" of equal protection review that is to be apphed in undefined circumstances. By this departure from our proper function as judges, the majority has created an unharnessed judicial force that presumably can be used to undo the work of the legislature whenever it is not to the liking of a majority of the members of this court.

Justice Carr, in his concurring opinion, states that he would rest today's decision on a common law extension of comparative negligence principles. His approach is based on an unrealistic interpretation of our comparative neghigence statute. The legislature has clearly expressed itself on the subject of comparative neghigence, first in 1931 and most recently witl the 1971 amendment to the statute. ${ }^{145}$ There is no room for judicial lawmaking in this area. My views on the cut-off feature of our rule of partial comparative negligence parallel those of Professor Campbell:

It should be repealed. [But] [t]his is a statutory rule and the court is helpless. If the legislature had never developed a comparative negligence doctrine, our supreme court might feel free to act. However, the right of the claimant is now controlled by the 1931 statute. The change should be made, but it will require action by the Wisconsm legislature.

Campbell, 1962 Wis. L. Rev. at 569.

I respectfully dissent.

144. There is nearly on-point authority at the federal level for rejecting the constitutional challenge we face today. In Duke Power Co. v. Carolina Environmental Study Group, Inc., 438 U.S. 59 (1978), the United States Supreme Court dealt with an attack on the so-called "Price-Anderson Act," 42 U.S.C. $\$ 2210$ (1976), which places a $\$ 560$ million overall limitation on liabihty for nuclear accidents resulting from the operation of federally hicensed private power plants. Giving great deference to the legislature in the area of tort law, the Court applied the rational basis standard and concluded that the liability limitation imposed by the Congress passed inuster under the due process clause of the fifth aunendinent and its equal protection component. 438 U.S. at $82-$ 94. The Court expressly rejected an intermediate review of the sort that the majority creates today. Id. at 83-84. "That the accommodation struck may have profound and far-reaching consequences ... provides all the more reason for this Court to defer to the congressional judginent unless it is demonstrably arbitrary or irrational." Id. (footnote omitted).

145. See notes 14-15 supra and accompanying text. 